\title{
Total Synthesis of Aquatolide: Wolff Ring Contraction and Late-Stage Nozaki-Hiyama-Kishi Medium Ring Formation
}

\section{Supporting Information}

Bin Wang, ${ }^{\dagger}$ Yuanzhen Xie, ${ }^{\dagger}$ Qin Yang, ${ }^{\ddagger}$ Guozhu Zhang*^ and Zhenhua Gu*

${ }^{\dagger}$ Department of Chemistry, University of Science and Technology of China, 96 Jinzhai Road, Hefei, Anhui 230026, P. R. China.

${ }^{\ddagger}$ State Key Laboratory of Organometallic Chemistry, Shanghai Institute of Organic Chemistry, Chinese Academy of Sciences, 345 Lingling Road, Shanghai 200032, P. R. China.

zhgu@ustc.edu.cn;

guozhuzhang@sioc.ac.cn 


\section{Table of Contents}

General Information---1--

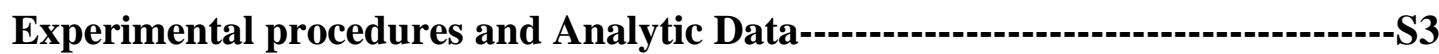

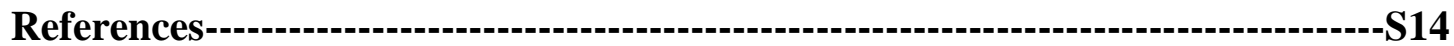

Table S1: Comparison of NMR data of Synthetic Aquatolide with Natural

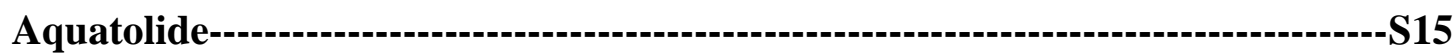

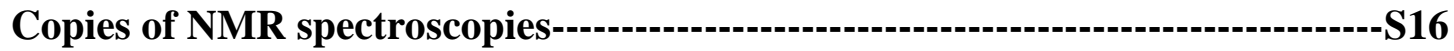




\section{General Information}

Nuclear magnetic resonances were recorded on Bruker- $400 \mathrm{MHz}$ instruments internally referenced to tetramethylsilane $(0.0 \mathrm{ppm})$ or residue of $\mathrm{CDCl}_{3}(7.26 \mathrm{ppm}$ for ${ }^{1} \mathrm{H}$, and $77.00 \mathrm{ppm}$ for ${ }^{13} \mathrm{C}$ ) signals. HRMS spectra were recorded on P-SIMS-Gly of Bruker Daltonics Inc and Water XEVO G2 Q-TOF (Waters Corporation). All reactions were performed under $\mathrm{N}_{2}$ in flame-dried glassware, unless otherwise stated. Solvents were distilled using standard techniques. Tetrahydrofuran was distilled over sodium under an atmosphere of nitrogen. Toluene, triethylamine, dimethyl sulfoxide and dichloromethane were distilled over calcium hydride. Methanol was dried by magnesium under an atmosphere of nitrogen. Room temperature reactions were performed between $20-35{ }^{\circ} \mathrm{C}$.

\section{Experimental procedures}

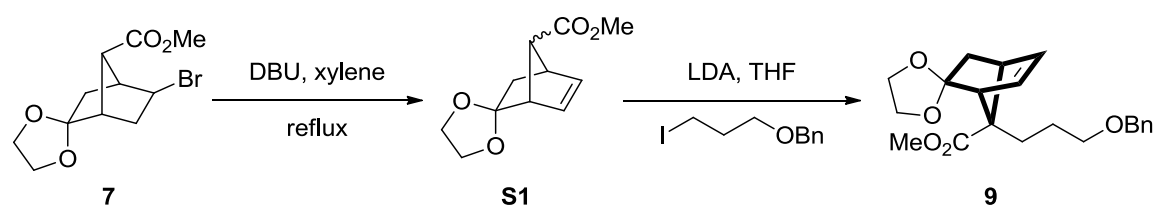

Bromide 7 (2.91 g, 10.0 mmol, 1.0 equiv) was added to a solution of DBU (7.90 $\mathrm{mL}, 50.0 \mathrm{mmol}, 5.0$ equiv) in xylene $(30 \mathrm{~mL})$. The resulting mixture was stirred at reflux until the complete consumption of starting material. After cooling to room temperature, a aqueous ammonium chloride solution was added and the mixture was extracted with EtOAc. The combined organic layer was washed with brine, dried over $\mathrm{Na}_{2} \mathrm{SO}_{4}$, filtrated and concentrated. The crude mixture was filtered off through a short pad of silica gel (10\% EtOAc in hexanes) to afford a mixture of diastereomers olefin S1 (1.19 g, $5.7 \mathrm{mmol}, 59 \%)$

$n$-Butyllithium (2.4 $M$ in THF, $3.10 \mathrm{~mL}, 7.40 \mathrm{mmol}, 1.3$ equiv) was added dropwise to a solution of diisopropylamine $(1.10 \mathrm{~mL}, 7.90 \mathrm{mmol}, 1.4$ equiv) in THF $(15 \mathrm{~mL})$ at $-78^{\circ} \mathrm{C}$ and stirred for $30 \mathrm{~min}$. Olefin S1 (1.19 g, $5.70 \mathrm{mmol}, 1.0$ equiv) in THF $(5 \mathrm{~mL})$ was added over $5 \mathrm{~min}$ to the above LDA solution. After stirring at $-78{ }^{\circ} \mathrm{C}$ for $1 \mathrm{~h}, 3$-iodo-1-propanol benzyl ether ( $2.04 \mathrm{~g}, 7.40 \mathrm{mmol}, 1.3$ equiv) in THF ( $2 \mathrm{~mL})$ was slowly added to the mixture and stirred at $-20{ }^{\circ} \mathrm{C}$ overnight. A solution of saturated $\mathrm{NH}_{4} \mathrm{Cl}$ was added and the mixture was extracted with EtOAc three times. The combined organic layer was washed with brine, dried over sodium sulfate and concentrated. The crude product was purified by column chromatography on silica gel (20\% EtOAc in hexanes) to give the desired product $9(1.77 \mathrm{~g}, 87 \%)$.

${ }^{1} \mathbf{H}$ NMR $\left(400 \mathrm{MHz}, \mathrm{CDCl}_{3}\right) \delta$ 7.38-7.23 (m, $\left.5 \mathrm{H}\right), 6.23(\mathrm{dd}, J=5.6,2.8 \mathrm{~Hz}, 1 \mathrm{H})$, $6.06(\mathrm{dd}, J=5.6,2.8 \mathrm{~Hz}, 1 \mathrm{H}), 4.45(\mathrm{~s}, 2 \mathrm{H}), 4.00-3.90(\mathrm{~m}, 1 \mathrm{H}), 3.88-3.79(\mathrm{~m}, 3 \mathrm{H})$, $3.68(\mathrm{~s}, 3 \mathrm{H}), 3.37(\mathrm{t}, J=6.4 \mathrm{~Hz}, 2 \mathrm{H}), 2.98(\mathrm{~s}, 1 \mathrm{H}), 2.81(\mathrm{~s}, 1 \mathrm{H}), 2.31(\mathrm{dd}, J=12.8$, $3.6 \mathrm{~Hz}, 1 \mathrm{H}), 1.91(\mathrm{td}, J=12.8,4.4 \mathrm{~Hz}, 1 \mathrm{H}), 1.65(\mathrm{td}, J=12.4,4.4 \mathrm{~Hz}, 1 \mathrm{H})$, 1.60-1.49 (m, $2 \mathrm{H}), 1.46-1.34(\mathrm{~m}, 1 \mathrm{H}) ;{ }^{13} \mathbf{C} \mathbf{N M R}\left(100 \mathrm{MHz}, \mathrm{CDCl}_{3}\right) \delta 175.1,138.5$, 137.2, 131.5, 128.3, 127.55, 127.47, 117.0, 72.7, 70.6, 70.2, 64.12, 64.09, 55.4, 51.3, 45.2, 38.7, 27.9, 26.3; HRMS (ESI) calcd for $\mathrm{C}_{21} \mathrm{H}_{26} \mathrm{O}_{5} \mathrm{Na}[\mathrm{M}+\mathrm{Na}]^{+} 381.1678$, found 381.1685 . 


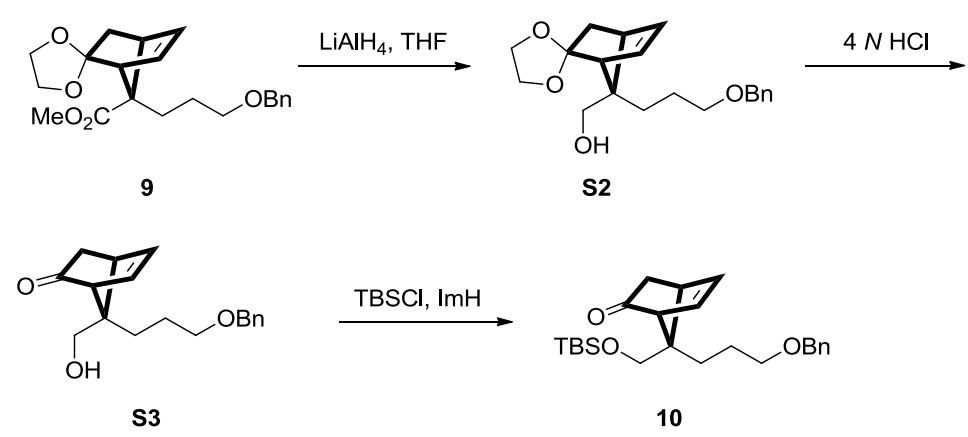

Lithium aluminium hydride ( $1.41 \mathrm{~g}, 36.4 \mathrm{mmol}, 3.0$ equiv) was added in portions to a solution of $9(4.35 \mathrm{~g}, 12.10 \mathrm{mmol}, 1.0$ equiv $)$ in $\mathrm{THF}(120 \mathrm{~mL})$ at $0{ }^{\circ} \mathrm{C}$ and stirred at $60{ }^{\circ} \mathrm{C}$ for $6 \mathrm{~h}$. After cooling to room temperature, the mixture was chilled to $0{ }^{\circ} \mathrm{C}$ and $\mathrm{H}_{2} \mathrm{O}(1.41 \mathrm{~mL})$ was added. After stirring for $10 \mathrm{~min}, 15 \% \mathrm{NaOH}(2.82 \mathrm{~mL})$ was added and 10 min later $\mathrm{H}_{2} \mathrm{O}(4.23 \mathrm{~mL})$ was added. The white solid was filtered off, (EtOAc), and the filtrate was dried over $\mathrm{Na}_{2} \mathrm{SO}_{4}$ and concentrated. The crude product was filtered off through a short pad of silica gel (50\% EtOAc in hexanes) to give the product S2 (3.79 g, 95\%) which was used in next step without further purification.

Under air atmosphere, $\mathrm{HCl}(4 \mathrm{~N}, 30 \mathrm{~mL})$ was added to a solution of $\mathbf{S 2}(3.79 \mathrm{~g}$, $11.30 \mathrm{mmol})$ in THF $(30 \mathrm{~mL})$ and stirred at $60{ }^{\circ} \mathrm{C}$ overnight. After cooling to room temperature, the mixture was extracted with EtOAc three times. The combined organic layer was washed with saturated aqueous solution of $\mathrm{NaHCO}_{3}$ and brine, dried over $\mathrm{Na}_{2} \mathrm{SO}_{4}$, filtered and concentrated with evaporation. The crude product was purified by column chromatography on silica gel (30\% EtOAc in hexanes) to give the product $\mathbf{S 3}$ (2.98 g, 82\% for two steps).

${ }^{1}$ H NMR $\left(400 \mathrm{MHz}, \mathrm{CDCl}_{3}\right) \delta 7.38-7.27(\mathrm{~m}, 5 \mathrm{H}), 6.55(\mathrm{dd}, J=4.0,2.0 \mathrm{~Hz}, 1 \mathrm{H})$, 6.02-5.87 (m, $1 \mathrm{H}), 4.49$ (s, $2 \mathrm{H}), 3.67-3.54(\mathrm{~m}, 2 \mathrm{H}), 3.48-3.35(\mathrm{~m}, 2 \mathrm{H}), 2.99(\mathrm{~s}, 1 \mathrm{H})$ $2.74(\mathrm{~s}, 1 \mathrm{H}), 2.25(\mathrm{~d}, J=17.2 \mathrm{~Hz}, 1 \mathrm{H}), 1.90(\mathrm{~d}, J=17.2 \mathrm{~Hz}, 1 \mathrm{H}), 1.84-1.66(\mathrm{~m}, 2$ $\mathrm{H}), 1.62-1.38(\mathrm{~m}, 2 \mathrm{H}) ;{ }^{13} \mathbf{C}$ NMR $\left(100 \mathrm{MHz}, \mathrm{CDCl}_{3}\right) \delta 214.4,143.8,138.2,128.4$, 127.72, 127.67, 127.2, 73.1, 70.6, 66.9, 62.4, 60.9, 45.2, 35.4, 26.1, 24.2; HRMS (ESI) calcd for $\mathrm{C}_{18} \mathrm{H}_{23} \mathrm{O}_{3}[\mathrm{M}+\mathrm{H}]^{+} 287.1642$, found 287.1637 .

tert-Butyldimethylsilyl chloride (3.04 g, $20.20 \mathrm{mmol}, 2.0$ equiv) was added in portions to a mixture of the $\mathbf{S 3}$ ( $2.89 \mathrm{~g}, 10.10 \mathrm{mmol}, 1.0$ equiv), and imidazole ( $2.75 \mathrm{~g}$, $40.4 \mathrm{mmol}, 4.0$ equiv) in DMF (15 mL) at room temperature then stirred overnight. The mixture was diluted with $\mathrm{H}_{2} \mathrm{O}$ and extracted with EtOAc. The organic layer was washed with water (five times) and brine, and dried over $\mathrm{Na}_{2} \mathrm{SO}_{4}$ and concentrated. The residue was purified by column chromatography on silica gel (5\% EtOAc in hexanes) to give $\mathbf{1 0}(3.75 \mathrm{~g}, 93 \%)$.

${ }^{1}$ H NMR $\left(400 \mathrm{MHz}, \mathrm{CDCl}_{3}\right) \delta$ 7.38-7.24 (m, $\left.5 \mathrm{H}\right), 6.53(\mathrm{dd}, J=5.6,2.8 \mathrm{~Hz}, 1 \mathrm{H})$, 5.97-5.91 (m, $1 \mathrm{H}), 4.48(\mathrm{~s}, 2 \mathrm{H}), 3.58(\mathrm{~d}, J=11.2 \mathrm{~Hz}, 1 \mathrm{H}), 3.52(\mathrm{~d}, J=11.2 \mathrm{~Hz}, 1 \mathrm{H})$, $3.40(\mathrm{t}, J=6.8 \mathrm{~Hz}, 2 \mathrm{H}), 2.95(\mathrm{~s}, 1 \mathrm{H}), 2.71(\mathrm{dd}, J=3.2,1.6 \mathrm{~Hz}, 1 \mathrm{H}), 2.21(\mathrm{dd}, J=$ $16.8,2.8 \mathrm{~Hz}, 1 \mathrm{H}), 1.88(\mathrm{~d}, J=16.8 \mathrm{~Hz}, 1 \mathrm{H}), 1.78-1.64(\mathrm{~m}, 2 \mathrm{H}), 1.60-1.50(\mathrm{~m}, 1 \mathrm{H})$, 1.50-1.37 (m, $1 \mathrm{H}), 0.87$ (s, $9 \mathrm{H}), 0.02$ (s, $3 \mathrm{H}), 0.01(\mathrm{~s}, 3 \mathrm{H}) ;{ }^{13} \mathrm{C}$ NMR $(100 \mathrm{MHz}$, $\left.\mathrm{CDCl}_{3}\right) \delta 214.5,143.8,138.5,128.3,127.54,127.47,127.3,72.8,70.7,67.0,62.9$, 60.7, 45.6, 35.5, 26.5, 25.8, 24.6, 18.1, -5.7; HRMS (ESI) calcd for $\mathrm{C}_{24} \mathrm{H}_{36} \mathrm{O}_{3} \mathrm{SiNa}$ $[\mathrm{M}+\mathrm{Na}]^{+} 423.2331$, found 423.2323 . 


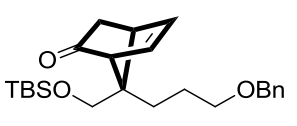

10

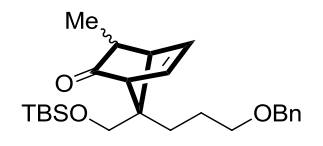

S4

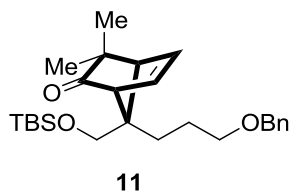

$n$-Butyllithium (2.4 $M$ in THF, $19.4 \mathrm{~mL}, 46.60 \mathrm{mmol}, 5.0$ equiv) was added dropwise to a solution of diisopropylamine $(6.7 \mathrm{~mL}, 47.5 \mathrm{mmol}, 5.1$ equiv) in THF $(700 \mathrm{~mL})$ at $-78{ }^{\circ} \mathrm{C}$ and stirred for $30 \mathrm{~min}$. Ketone 10 (3.72 g, $9.30 \mathrm{mmol}, 1.0$ equiv) in THF $(50 \mathrm{~mL})$ was added to the above solution over $20 \mathrm{~min}$ at $-78{ }^{\circ} \mathrm{C}$ and stirred for $2 \mathrm{~h}$. Iodomethane ( $3.00 \mathrm{~mL}, 47.70 \mathrm{mmol}, 5.1$ equiv) was added and the mixture was allowed to warm to room temperature and stirred for $24 \mathrm{~h}$. A saturated solution of $\mathrm{NH}_{4} \mathrm{Cl}$ was added and the volatiles were removed by evaporation and the aqueous layer was extracted with EtOAc (three times). The combined organic layer was washed with brine, dried over sodium sulfate and concentrated. The residue was filtered off through a short pad of silica gel (20\% EtOAc in hexanes) to afford a mixture of two inseparable diastereomers olefin $\mathbf{S 4}$ which was pure enough to be used in next step without further purification.

Sodium bis(trimethylsilyl)amide (2.0 $\mathrm{M}$ in THF, $23.0 \mathrm{~mL}, 46.50 \mathrm{mmol}, 5.0$ equiv) was slowly added to a solution of the obtained ketone $\mathbf{S 4}(\sim 9.3 \mathrm{mmol}, 1.0$ equiv) and THF $(700 \mathrm{~mL})$ at $-20{ }^{\circ} \mathrm{C}$ and stirred at $0{ }^{\circ} \mathrm{C}$ for $2 \mathrm{~h}$. Iodomethane $(3.00 \mathrm{~mL}, 47.70$ mmol, 5.1 equiv) was added to this mixture and stirred at room temperature overnight. A saturated solution of $\mathrm{NH}_{4} \mathrm{Cl}$ was added and THF was removed by evaporation. The aqueous layer was extracted with EtOAc three times and the combined organic layer was washed with brine, dried over sodium sulfate and concentrated. The residue was purified by column chromatography on silica gel (5\% EtOAc in hexanes) to give the desired product $\mathbf{1 1}$ (3.96 g, 99\% for two steps).

${ }^{1} \mathbf{H}$ NMR $\left(400 \mathrm{MHz}, \mathrm{CDCl}_{3}\right) \delta$ 7.39-7.22 (m, $\left.5 \mathrm{H}\right), 6.56(\mathrm{dd}, J=5.6,3.2 \mathrm{~Hz}, 1 \mathrm{H})$, 5.94-5.85 (m, $1 \mathrm{H}), 4.47(\mathrm{~s}, 2 \mathrm{H}), 3.52(\mathrm{~s}, 2 \mathrm{H}), 3.38(\mathrm{t}, J=6.6 \mathrm{~Hz}, 2 \mathrm{H}), 2.77(\mathrm{~s}, 1 \mathrm{H})$, $2.66(\mathrm{~s}, 1 \mathrm{H}), 1.77-1.65(\mathrm{~m}, 2 \mathrm{H}), 1.54-1.43(\mathrm{~m}, 1 \mathrm{H}), 1.42-1.30(\mathrm{~m}, 1 \mathrm{H}), 1.28(\mathrm{~s}, 3 \mathrm{H})$, 1.03 (s, $3 \mathrm{H}), 0.87$ (s, $9 \mathrm{H}), 0.01(\mathrm{~s}, 3 \mathrm{H}),-0.01$ (s, $3 \mathrm{H}) ;{ }^{13} \mathbf{C ~ N M R}\left(100 \mathrm{MHz}, \mathrm{CDCl}_{3}\right)$ $\delta 221.9,145.0,138.5,128.3,127.5,127.4,125.8,72.8,70.7,66.7,63.0,61.5,56.0$, $42.9,30.9,26.5,26.1,25.8,24.8,18.1,-5.6,-5.7$; HRMS (ESI) calcd for $\mathrm{C}_{26} \mathrm{H}_{40} \mathrm{O}_{3} \mathrm{SiNa}[\mathrm{M}+\mathrm{Na}]^{+}$451.2644, found 451.2643.

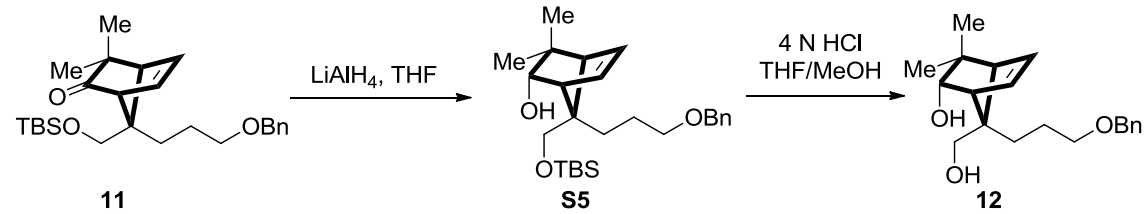

Lithium aluminium hydride $(0.70 \mathrm{~g}, 18.5 \mathrm{mmol}, 2.0$ equiv) was slowly added (in portions) to a solution of $\mathbf{1 1}\left(3.96 \mathrm{~g}, 9.30 \mathrm{mmol}, 1.0\right.$ equiv) in THF $(150 \mathrm{~mL})$ at $-20{ }^{\circ} \mathrm{C}$ 
and stirred at the same temperature for $4 \mathrm{~h}$. A saturated solution of potassium sodium tartrate $100 \mathrm{~mL}$ was added and stirred at room temperature for $2 \mathrm{~h}$. The solid was filtered off and the filtrate was extracted with EtOAc three times. The combined organic layer was washed with brine, dried over sodium sulfate and concentrated to afford crude product $\mathbf{S 5}$.

Hydrochloric acid $(4 N, 20 \mathrm{~mL})$ was added to a mixture of the olefin $\mathbf{S 5}(\sim 9.3$ $\mathrm{mmol})$ in $\mathrm{MeOH}(20 \mathrm{~mL})$ and THF $(20 \mathrm{~mL})$ at room temperature stirred overnight. The mixture was extracted with EtOAc, washed with a saturated solution of $\mathrm{NaHCO}_{3}$ and brine, dried over $\mathrm{Na}_{2} \mathrm{SO}_{4}$, filtered and concentrated. The residue was purified by column chromatography on silica gel (25\% EtOAc in hexanes) to give the desired product 12 (2.74 g, 94\% for two steps).

${ }^{1} \mathbf{H}$ NMR $\left(400 \mathrm{MHz}, \mathrm{CDCl}_{3}\right) \delta$ 7.38-7.23 (m, $\left.5 \mathrm{H}\right), 6.20(\mathrm{dd}, J=5.6,2.8 \mathrm{~Hz}, 1 \mathrm{H})$, 5.95-5.84 (m, $1 \mathrm{H}), 4.47(\mathrm{~s}, 2 \mathrm{H}), 4.14(\mathrm{~d}, J=11.6 \mathrm{~Hz}, 1 \mathrm{H}), 3.95(\mathrm{~d}, J=11.6 \mathrm{~Hz}, 1 \mathrm{H})$, $3.47(\mathrm{~s}, 1 \mathrm{H}), 3.38(\mathrm{t}, J=6.5 \mathrm{~Hz}, 2 \mathrm{H}), 2.55-2.50(\mathrm{~m}, 1 \mathrm{H}), 2.25(\mathrm{t}, J=2.1 \mathrm{~Hz}, 1 \mathrm{H})$, 2.14 (br s, 2 H), 1.67-1.36 (m, 4 H), 1.23 (s, 3 H), 0.94 (s, 3 H),${ }^{13}$ C NMR (100 MHz, $\left.\mathrm{CDCl}_{3}\right) \delta 139.8,138.5,130.0,128.3,127.6,127.5,81.8,72.9,71.0,67.4,62.9,57.5$, 55.4, 40.6, 32.2, 28.8, 26.9, 24.3; HRMS (ESI) calcd for $\mathrm{C}_{20} \mathrm{H}_{28} \mathrm{O}_{3} \mathrm{Na}[\mathrm{M}+\mathrm{Na}]^{+}$ 339.1936 , found 339.1931 .

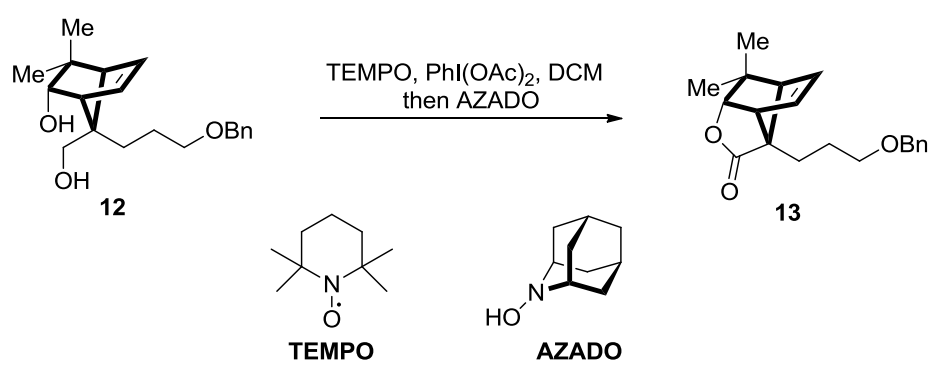

Iodobenzene diacetate $(16.11 \mathrm{~g}, 50.00 \mathrm{mmol}, 4.0$ equiv) was added to a mixture of TEMPO (0.20 g, $1.25 \mathrm{mmol}, 10 \mathrm{~mol} \%)$ and diol 12 (3.94 g, $12.50 \mathrm{mmol}, 1.0$ equiv) in dichloromethane $(150 \mathrm{~mL})$ at room temperature and stirred for $48 \mathrm{~h}$. 2-Hydroxy-2-azaadamantane (AZADO) $(57.0 \mathrm{mg}, 0.38 \mathrm{mmol}, 4.0 \mathrm{~mol} \%)$ was added to the resulting mixture and stirred for additional $48 \mathrm{~h}$. A solution of $\mathrm{NaHCO}_{3}$ and $\mathrm{Na}_{2} \mathrm{SO}_{3}$ was added and the resulting mixture was extracted with DCM. The organic layer was washed with brine, dried over $\mathrm{Na}_{2} \mathrm{SO}_{4}$ and concentrated. The residue was purified by column chromatography on silica gel (5\% EtOAc in hexanes) to give the desired product $13(2.44 \mathrm{~g}, 63 \%)$.

${ }^{1} \mathbf{H}$ NMR $\left(400 \mathrm{MHz}, \mathrm{CDCl}_{3}\right) \delta$ 7.40-7.23 (m, $\left.5 \mathrm{H}\right), 6.32(\mathrm{dd}, J=5.6,2.8 \mathrm{~Hz}, 1 \mathrm{H})$, $5.84(\mathrm{ddd}, J=5.7,2.9,1.2 \mathrm{~Hz}, 1 \mathrm{H}), 4.47(\mathrm{~s}, 2 \mathrm{H}), 4.01(\mathrm{~d}, J=2.0 \mathrm{~Hz}, 1 \mathrm{H}), 3.50-3.38$ (m, $2 \mathrm{H}), 3.37-3.27(\mathrm{~m}, 1 \mathrm{H}), 2.23(\mathrm{~s}, 1 \mathrm{H}), 1.80-1.40(\mathrm{~m}, 4 \mathrm{H}), 1.12(\mathrm{~s}, 3 \mathrm{H}), 0.81$ (s, $3 \mathrm{H}) ;{ }^{13} \mathrm{C}$ NMR $\left(100 \mathrm{MHz}, \mathrm{CDCl}_{3}\right) \delta 177.2,138.6,138.5,128.3,127.6,127.4,126.0$, 83.5, 74.8, 72.7, 70.2, 61.3, 57.2, 43.4, 26.8, 24.43, 24.38, 22.0; HRMS (ESI) calcd for $\mathrm{C}_{20} \mathrm{H}_{24} \mathrm{O}_{3} \mathrm{Na}[\mathrm{M}+\mathrm{Na}]^{+}$335.1623, found 335.1622. 


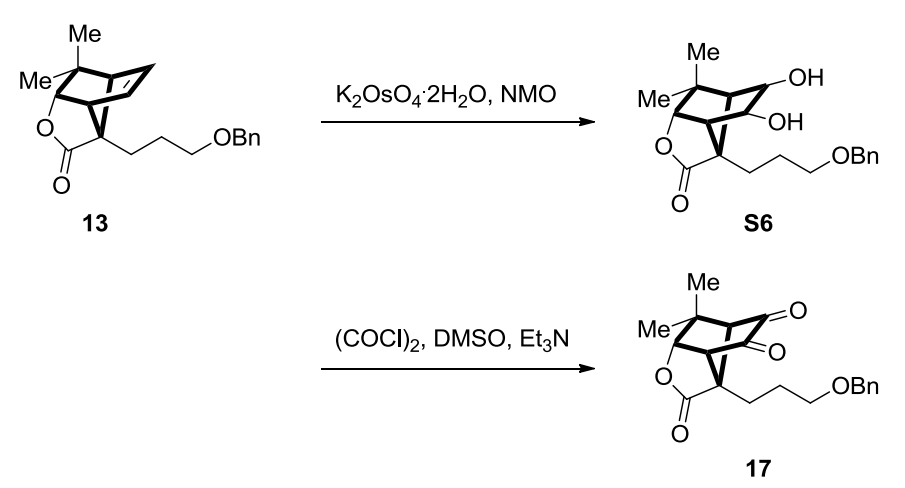

$N$-Methylmorpholine $N$-oxide $(4.90 \mathrm{~mL}, 50 \% \mathrm{wt}, 4.0$ equiv) was added to a mixture of 13 (1.64 g, $5.2 \mathrm{mmol}, 1.0$ equiv), $\mathrm{K}_{2} \mathrm{OsO}_{4} \cdot 2 \mathrm{H}_{2} \mathrm{O}(80.0 \mathrm{mg}, 0.21 \mathrm{mmol}, 4.0$ $\mathrm{mol} \%), t-\mathrm{BuOH}(15 \mathrm{~mL}), \mathrm{H}_{2} \mathrm{O}(15 \mathrm{~mL})$ and acetone $(15 \mathrm{~mL})$ at room temperature and stirred for $60 \mathrm{~h}$. The resulting mixture was extracted five times with EtOAc, washed with brine, dried over $\mathrm{Na}_{2} \mathrm{SO}_{4}$ and concentrated. The residue was filtered through a short pad of silica gel (ethyl acetate) to afford crude S6.

Dimethyl sulfoxide (3.69 mL, $52.0 \mathrm{mmol}, 10.0$ equiv) was slowly added to a solution of $(\mathrm{COCl})_{2}\left(2.21 \mathrm{~mL}, 26.0 \mathrm{mmol}, 5.0\right.$ equiv) in DCM $(100 \mathrm{~mL})$ at $-78{ }^{\circ} \mathrm{C}$ and stirred for $45 \mathrm{~min}$. The above crude diol $\mathbf{S 6}$ in DCM $(30 \mathrm{~mL})$ was added at $-78{ }^{\circ} \mathrm{C}$ and stirred for $2.5 \mathrm{~h}$. Triethyl amine $(8.67 \mathrm{~mL}, 62.4 \mathrm{mmol}, 12.0$ equiv) was added to the mixture and stirred for additional $2 \mathrm{~h}$. After removing the cooling bath, the mixture was allowed to warm to room temperature and stirred for $20 \mathrm{~min}$. Water was added, and the mixture was extracted with DCM. The combined organic layer was washed with brine, dried over $\mathrm{Na}_{2} \mathrm{SO}_{4}$ and concentrated. The residue was purified by column chromatography on silica gel (20\% EtOAc in hexanes) to give diketone 17 (1.67 g, 93\% for two steps).

${ }^{1} \mathbf{H}$ NMR $\left(400 \mathrm{MHz}, \mathrm{CDCl}_{3}\right) \delta$ 7.42-7.18 (m, $\left.5 \mathrm{H}\right), 4.55-4.35(\mathrm{~m}, 3 \mathrm{H}), 3.64(\mathrm{~s}, 1$ $\mathrm{H}), 3.42(\mathrm{t}, J=5.8 \mathrm{~Hz}, 2 \mathrm{H}), 2.73(\mathrm{t}, J=1.3 \mathrm{~Hz}, 1 \mathrm{H}), 2.06-1.93(\mathrm{~m}, 1 \mathrm{H}), 1.75-1.60$ $(\mathrm{m}, 2 \mathrm{H}), 1.59-1.49(\mathrm{~m}, 1 \mathrm{H}), 1.23(\mathrm{~s}, 3 \mathrm{H}), 1.01(\mathrm{~s}, 3 \mathrm{H}) ;{ }^{13} \mathbf{C ~ N M R}\left(100 \mathrm{MHz}, \mathrm{CDCl}_{3}\right)$ $\delta$ 197.2, 196.2, 173.2, 138.0, 128.4, 127.7, 127.6, 84.0, 72.7, 69.2, 63.4, 62.4, 58.4, 42.2, 25.5, 24.7, 24.2, 23.4; HRMS (ESI) calcd for $\mathrm{C}_{20} \mathrm{H}_{22} \mathrm{O}_{5} \mathrm{Na}[\mathrm{M}+\mathrm{Na}]^{+}$365.1365, found 365.1363 .
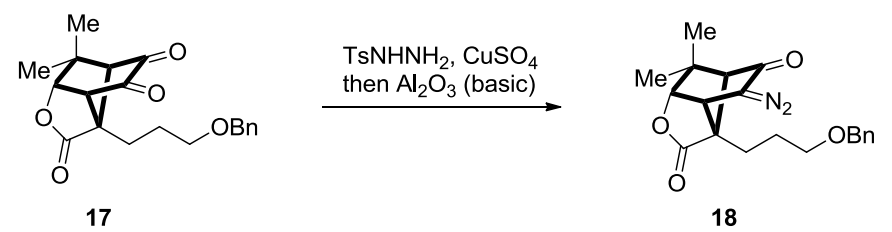

Copper(II) sulfate (2.31 g, $14.50 \mathrm{mmol}, 3.0$ equiv) was added to a mixture of 4-methylbenzenesulfonhydrazide (3.59 g, $19.30 \mathrm{mmol}, 4.0$ equiv) and diketone 17 ( $1.65 \mathrm{~g}, 4.80 \mathrm{mmol}, 1.0$ equiv) in toluene $(50 \mathrm{~mL})$ at room temperature and stirred in dark for 2.5 days. The resulting mixture was filtered through a pad of celite, washed with toluene and concentrated. The crude product was purified by column chromatography on $\mathrm{Al}_{2} \mathrm{O}_{3}$ (basic) (20\% EtOAc in hexanes) to give the desired diazo compound 18 (1.34 g, 79\%). 
${ }^{1} \mathbf{H}$ NMR $\left(400 \mathrm{MHz}, \mathrm{CDCl}_{3}\right) \delta$ 7.38-7.25 (m, $\left.5 \mathrm{H}\right), 4.54-4.40(\mathrm{~m}, 3 \mathrm{H}), 3.80(\mathrm{t}, J=$ $2.1 \mathrm{~Hz}, 1 \mathrm{H}), 3.55-3.41(\mathrm{~m}, 2 \mathrm{H}), 2.17(\mathrm{~d}, J=2.0 \mathrm{~Hz}, 1 \mathrm{H}), 2.00-1.86(\mathrm{~m}, 1 \mathrm{H})$, 1.80-1.58 (m, $3 \mathrm{H}), 1.17$ (s, $3 \mathrm{H}), 1.13$ (s, $3 \mathrm{H}) ;{ }^{\mathbf{1 3}} \mathbf{C}$ NMR $\left(100 \mathrm{MHz}, \mathrm{CDCl}_{3}\right) \delta$ 195.0, 173.9, 138.2, 128.4, 127.7, 127.6, 84.1, 72.9, 69.7, 63.7, 63.2, 55.3, 52.6, 42.2, 25.9, 24.6, 23.4, 23.2; HRMS (ESI) calcd for $\mathrm{C}_{20} \mathrm{H}_{22} \mathrm{~N}_{2} \mathrm{O}_{4} \mathrm{Na}[\mathrm{M}+\mathrm{Na}]^{+} 377.1472$, found 377.1467 .
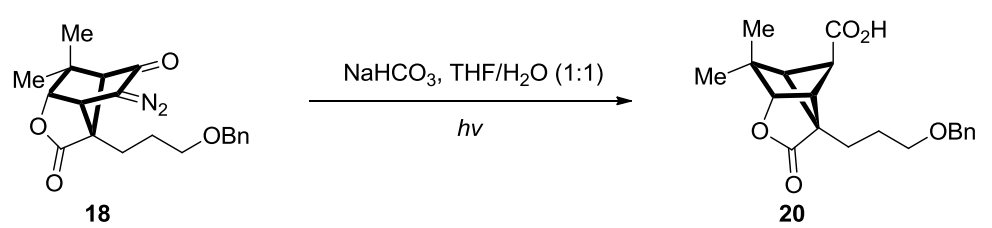

Sodium hydrogen carbonate $(67 \mathrm{mg}, 0.80 \mathrm{mmol}, 2.0$ equiv) was added to a mixture of 18 (0.140 g, $0.40 \mathrm{mmol}, 1.0$ equiv) in THF (4 mL) and $\mathrm{H}_{2} \mathrm{O}(4 \mathrm{~mL})$ at room temperature and sealed with screw cap. The resulting mixture was exposured to $125 \mathrm{~W}$ high pressure mercury lamp and stirred for 7 days. The reaction was quenched by a solution of saturated $\mathrm{NH}_{4} \mathrm{Cl}$ and extracted by EtOAc. The combined organic layer was washed with brine, dried over $\mathrm{Na}_{2} \mathrm{SO}_{4}$ and concentrated. The residue was purified by column chromatography on silica gel (50\% EtOAc in hexanes) to give two inseparable diastereomers 20 (110 mg, 80\%, dr 6.7:1).

The major isomer: ${ }^{1} \mathbf{H}$ NMR $\left(400 \mathrm{MHz}, \mathrm{CDCl}_{3}\right) \delta 7.38-7.27(\mathrm{~m}, 5 \mathrm{H}), 4.58(\mathrm{t}, J=$ $1.7 \mathrm{~Hz}, 1 \mathrm{H}), 4.52(\mathrm{~s}, 2 \mathrm{H}), 3.58-3.44(\mathrm{~m}, 2 \mathrm{H}), 3.20(\mathrm{dt}, J=6.5,2.0 \mathrm{~Hz}, 1 \mathrm{H}), 3.13(\mathrm{t}$, $J=2.6 \mathrm{~Hz}, 1 \mathrm{H}), 2.83-2.77(\mathrm{~m}, 1 \mathrm{H}), 2.04-1.93(\mathrm{~m}, 1 \mathrm{H}), 1.88-1.75(\mathrm{~m}, 1 \mathrm{H})$, 1.71-1.57 (m, $2 \mathrm{H}), 1.15$ (s, $3 \mathrm{H}), 1.01(\mathrm{~s}, 3 \mathrm{H}) ;{ }^{\mathbf{1 3}} \mathbf{C} \mathbf{N M R}\left(100 \mathrm{MHz}, \mathrm{CDCl}_{3}\right) \delta 177.5$, $137.9,128.4,127.8,127.7,127.5,84.3,72.9,69.8,61.9,58.9,53.9,41.5,26.6,23.9$, 22.3, 22.0; HRMS (ESI) calcd for $\mathrm{C}_{20} \mathrm{H}_{24} \mathrm{O}_{5} \mathrm{Na}\left[\mathrm{M}^{+}+\mathrm{Na}\right] 367.1516$, found 367.1514.
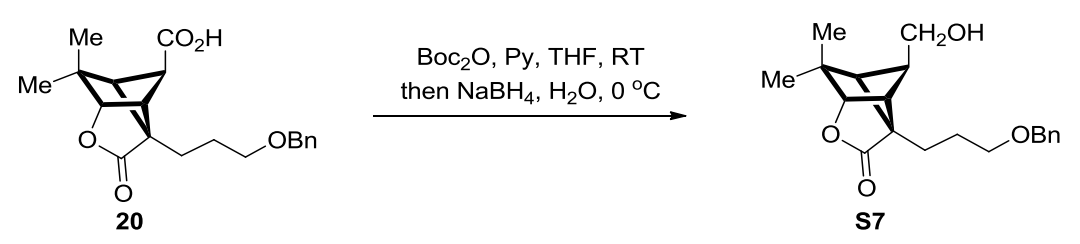

Di-tert-butyl dicarbonate ( $0.350 \mathrm{~g}, 1.60 \mathrm{mmol}, 2.0$ equiv) was slowly added to a mixture of 20 ( $0.270 \mathrm{~g}, 0.79 \mathrm{mmol}, 1.0$ equiv) and pyridine $(0.26 \mathrm{~mL}, 3.20 \mathrm{mmol}, 4.0$ equiv) in THF $(10 \mathrm{~mL})$ at room temperature and stirred overnight. $\mathrm{NaBH}_{4}(0.240 \mathrm{~g}$, $6.40 \mathrm{mmol}, 8.0$ equiv) was slowly added to the resulting mixture at $0{ }^{\circ} \mathrm{C}$, followed by the addition of $\mathrm{H}_{2} \mathrm{O}(1.0 \mathrm{~mL})$ and stirred for additional $4 \mathrm{~h}$ at $0{ }^{\circ} \mathrm{C}$. The reaction was quenched by the addition of a solution of saturated $\mathrm{NH}_{4} \mathrm{Cl}$. The mixture was extracted with EtOAc, and organic layer was washed with brine, dried over $\mathrm{Na}_{2} \mathrm{SO}_{4}$ and concentrated. The residue was purified by column chromatography on silica gel $(25 \%$ EtOAc in hexanes) to give two inseparable diastereomers product $\mathbf{S 7}(0.166 \mathrm{~g}, 63 \%$, dr 10:1) and acid 20 (98.0 mg, 35\%, dr 3.3:1).

The major isomer (S7): ${ }^{1} \mathbf{H}$ NMR $\left(400 \mathrm{MHz}, \mathrm{CDCl}_{3}\right) \delta$ 7.39-7.26 (m, $\left.5 \mathrm{H}\right)$, 4.54-4.46 (m, $3 \mathrm{H}), 3.68$ (d, $J=4.4 \mathrm{~Hz}, 2 \mathrm{H}), 3.58-3.40$ (m, $2 \mathrm{H}$ ), 3.14 (dt, $J=7.2,2.4$ 
$\mathrm{Hz}, 1 \mathrm{H}), 2.64-2.57(\mathrm{~m}, 1 \mathrm{H}), 2.54(\mathrm{dt}, J=7.2,2.0 \mathrm{~Hz}, 1 \mathrm{H}), 2.04-1.92(\mathrm{~m}, 1 \mathrm{H})$, 1.87-1.76 (m, $1 \mathrm{H}), 1.71-1.59(\mathrm{~m}, 2 \mathrm{H}), 1.15(\mathrm{~s}, 3 \mathrm{H}), 1.01$ (s, $3 \mathrm{H}) ;{ }^{13} \mathbf{C}$ NMR $(100$ $\left.\mathrm{MHz}, \mathrm{CDCl}_{3}\right) \delta 178.5,138.4,128.4,127.7,127.6,85.7,72.9,70.1,62.6,62.5,60.5$, $56.4,46.4,40.9,26.9,25.0,23.9,22.1$; HRMS (ESI) calcd for $\mathrm{C}_{20} \mathrm{H}_{26} \mathrm{O}_{4} \mathrm{Na}[\mathrm{M}+\mathrm{Na}]^{+}$ 353.1729 , found 353.1727 .
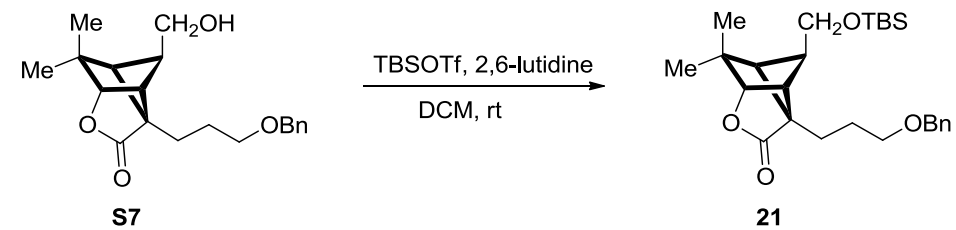

tert-Butyldimethylsilyl trifluoromethanesulfonate $(0.23 \mathrm{~mL}, 1.00 \mathrm{mmol}, 2.0$ equiv) was added slowly to a solution of $\mathbf{S 7}(0.166 \mathrm{~g}, 0.50 \mathrm{mmol}, 1.0$ equiv, $\mathrm{dr} 4.2: 1)$ and 2,6-lutidine $(0.23 \mathrm{~mL}, 2.00 \mathrm{mmol}, 4.0$ equiv) in DCM $(5 \mathrm{~mL})$ at room temperature and stirred overnight. Water was added and the resulting mixture was extracted with DCM. The combined organic layer was washed with brine, dried over $\mathrm{Na}_{2} \mathrm{SO}_{4}$ and concentrated. The crude product was purified by column chromatography on silica gel (10\% EtOAc in hexanes) to give two inseparable diastereomers product 21 ( $0.188 \mathrm{~g}$, $84 \%$, dr 4.2:1).

The major isomer: ${ }^{1} \mathbf{H}$ NMR (400 MHz, $\left.\mathrm{CDCl}_{3}\right) \delta$ 7.37-7.31 (m, $\left.5 \mathrm{H}\right)$, 4.52-4.48 $(\mathrm{m}, 3 \mathrm{H}), 3.64(\mathrm{~d}, J=6.0 \mathrm{~Hz}, 2 \mathrm{H}), 3.55-3.48(\mathrm{~m}, 2 \mathrm{H}), 3.08(\mathrm{dt}, J=7.2,2.0 \mathrm{~Hz}, 1 \mathrm{H})$, 2.64-2.58 (m, $1 \mathrm{H}), 2.52-2.47(\mathrm{~m}, 1 \mathrm{H}), 2.02-1.92(\mathrm{~m}, 1 \mathrm{H}), 1.85-1.75(\mathrm{~m}, 1 \mathrm{H})$, 1.67-1.60 (m, $2 \mathrm{H}), 1.18$ (s, $3 \mathrm{H}), 1.01$ (s, $3 \mathrm{H}), 0.89$ (s, $9 \mathrm{H}), 0.040$ (s, $3 \mathrm{H}) 0.038$ (s, 3 $\mathrm{H}) ;{ }^{13} \mathrm{C}$ NMR $\left(100 \mathrm{MHz}, \mathrm{CDCl}_{3}\right) \delta 178.7,138.5,128.3,127.6,127.5,85.9,72.8,70.1$, $62.6,62.4,60.3,56.5,46.3,40.9,26.9,25.9,25.1,23.8,22.1,18.2,-5.28,-5.34$;

HRMS (ESI) calcd for $\mathrm{C}_{26} \mathrm{H}_{40} \mathrm{O}_{4} \mathrm{SiNa}[\mathrm{M}+\mathrm{Na}]^{+} 467.2594$, found 467.2592.

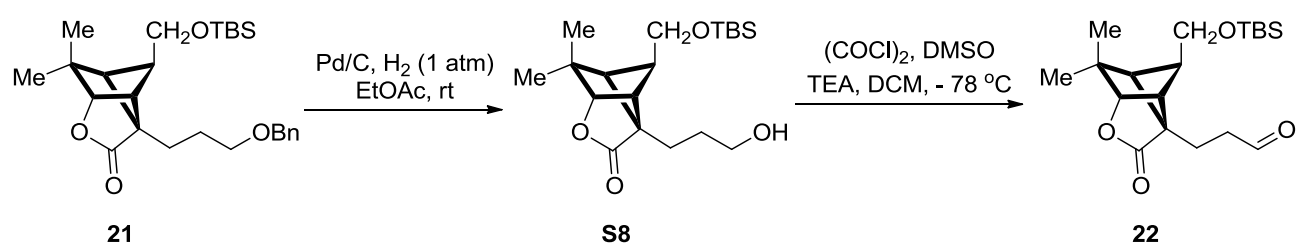

A flask containing a mixture of $21(130 \mathrm{mg}, 0.29 \mathrm{mmol}, 1.0$ equiv) and $10 \% \mathrm{Pd} / \mathrm{C}$ $(80 \mathrm{mg})$ in EtOAc $(4 \mathrm{~mL})$ was purged with $\mathrm{H}_{2}$ for $20 \mathrm{~min}$ and stirred at room temperature for $4 \mathrm{~h}$ with a balloon of $\mathrm{H}_{2}$. The mixture was filtered off through a short pad of silica gel (ethyl acetate) to afford a mixture of two inseparable diastereomers S8 which was used in next step without further purification.

Dimethyl sulfoxide (120 $\mu \mathrm{L}, 1.67 \mathrm{mmol}, 5.7$ equiv) was slowly added to a solution of $(\mathrm{COCl})_{2}(71 \mu \mathrm{L}, 0.84 \mathrm{mmol}, 2.9$ equiv $)$ in $\mathrm{DCM}(2 \mathrm{~mL})$ at $-78{ }^{\circ} \mathrm{C}$ and stirred for $45 \mathrm{~min}$. The above alcohol $\mathbf{S 8}$ in DCM $(1 \mathrm{~mL})$ was added and stirred for additional $2.5 \mathrm{~h}$. Subsequently $\mathrm{Et}_{3} \mathrm{~N}(0.30 \mathrm{~mL}, 2.23 \mathrm{mmol}, 7.7$ equiv) was added and the mixture was stirred for additional $2 \mathrm{~h}$ at $-78{ }^{\circ} \mathrm{C}$ and $20 \mathrm{~min}$ at room temperature. Water was added and the aqueous layer was extracted with DCM. The combined organic layer was washed with brine, dried over $\mathrm{Na}_{2} \mathrm{SO}_{4}$ and concentrated. The 
residue was purified by column chromatography on silica gel (10\% EtOAc in hexanes) to give a pair of inseparable diastereomers $22(78 \mathrm{mg}, 74 \%, \mathrm{dr} 4.2: 1)$.

The major isomer: ${ }^{1} \mathbf{H}$ NMR $\left(400 \mathrm{MHz}, \mathrm{CDCl}_{3}\right) \delta 9.80(\mathrm{~s}, 1 \mathrm{H}), 4.52(\mathrm{t}, J=2.0 \mathrm{~Hz}$, $1 \mathrm{H}), 3.65(\mathrm{~d}, J=5.6 \mathrm{~Hz}, 2 \mathrm{H}), 3.03(\mathrm{dt}, J=6.8,2.4 \mathrm{~Hz}, 1 \mathrm{H}), 2.70-2.63(\mathrm{~m}, 1 \mathrm{H})$, 2.60-2.50 (m, $3 \mathrm{H}), 2.26-2.15(\mathrm{~m}, 1 \mathrm{H}), 2.10-2.00(\mathrm{~m}, 1 \mathrm{H}), 1.20(\mathrm{~s}, 3 \mathrm{H}), 1.02(\mathrm{~s}, 3 \mathrm{H})$, 0.89 (s, $9 \mathrm{H}), 0.04$ (s, $6 \mathrm{H}) ;{ }^{13} \mathbf{C}$ NMR $\left(100 \mathrm{MHz}, \mathrm{CDCl}_{3}\right) \delta 201.1,178.3,86.1,62.4$, 62.2, 59.9, 56.8, 53.9, 46.4, 41.0, 25.9, 25.2, 23.7, 18.2, 17.8, -5.30, -5.35; HRMS (ESI) calcd for $\mathrm{C}_{19} \mathrm{H}_{32} \mathrm{O}_{4} \mathrm{SiNa}[\mathrm{M}+\mathrm{Na}]^{+} 375.1968$, found 375.1965 .
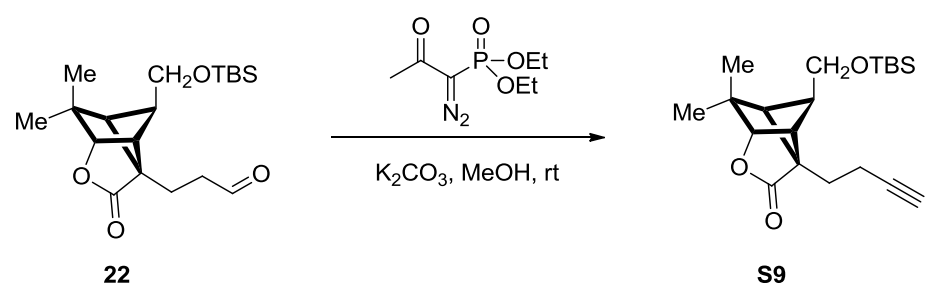

The Bestmann-Ohira reagent ( $98 \mathrm{mg}, 0.51 \mathrm{mmol}, 3.0$ equiv) was added to a mixture of 22 (62 mg, $0.17 \mathrm{mmol}, 1.0$ equiv) and $\mathrm{K}_{2} \mathrm{CO}_{3}(94 \mathrm{mg}, 0.68 \mathrm{mmol}, 4.0$ equiv) in $\mathrm{MeOH}(2 \mathrm{~mL})$ at room temperature and stirred for $3 \mathrm{~h}$. The resulting mixture was filtered through a pad of celite (with EtOAc). The filtrate was concentrated and the residue was purified by column chromatography on silica gel $(5 \%$ EtOAc in hexanes) to give a pair of inseparable diastereomers $\mathbf{S 9}$ (54 $\mathrm{mg}, 91 \%, \mathrm{dr}$ 4.2:1).

The major isomer: ${ }^{1} \mathbf{H}$ NMR $\left(400 \mathrm{MHz}, \mathrm{CDCl}_{3}\right) \delta 4.50(\mathrm{t}, J=1.8 \mathrm{~Hz}, 1 \mathrm{H}), 3.65$ $(\mathrm{d}, J=5.6 \mathrm{~Hz}, 2 \mathrm{H}), 3.25(\mathrm{dt}, J=7.2,2.0 \mathrm{~Hz}, 1 \mathrm{H}), 2.75-2.65(\mathrm{~m}, 1 \mathrm{H}), 2.60-2.50(\mathrm{~m}$, $1 \mathrm{H}), 2.37-2.13$ (m, $3 \mathrm{H}), 2.01-1.90(\mathrm{~m}, 2 \mathrm{H}), 1.18$ (s, $3 \mathrm{H}), 1.01$ (s, $3 \mathrm{H}), 0.89$ (s, $9 \mathrm{H})$, 0.04 (s, $6 \mathrm{H}) ;{ }^{13} \mathrm{C}$ NMR $\left(100 \mathrm{MHz}, \mathrm{CDCl}_{3}\right) \delta$ 178.3, 85.9, 83.7, 68.9, 62.5, 62.2, 60.2, 56.7, 46.3, 40.9, 25.9, 25.2, 24.4, 23.8, 18.2, 15.9, -5.3, -5.4; HRMS (ESI) calcd for $\mathrm{C}_{20} \mathrm{H}_{32} \mathrm{O}_{3} \mathrm{SiNa}[\mathrm{M}+\mathrm{Na}]^{+}$371.2018, found 371.2020.
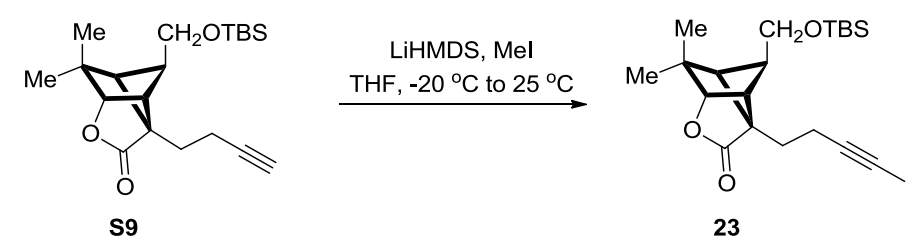

Lithium bis(trimethylsilyl)amide (1.0 M in THF, $1.5 \mathrm{~mL}, 10.0$ equiv) was added slowly to a solution of $\mathbf{S 9}$ (53 mg, $0.15 \mathrm{mmol}, 1.0$ equiv) in THF (2 mL) at $-20{ }^{\circ} \mathrm{C}$ and stirred for $20 \mathrm{~min}$. Iodomethane $(100 \mu \mathrm{l}, 1.50 \mathrm{mmol}, 10.0$ equiv) was added and the mixture was allowed to warm to room temperature and stirred for $1 \mathrm{~h}$. A saturated solution of $\mathrm{NH}_{4} \mathrm{Cl}$ was added and the mixture was extracted with EtOAc. The combined organic layer was washed with brine, dried over sodium sulfate and concentrated. The residue was purified by column chromatography on silica gel $(5 \%$ EtOAc in hexanes) to give a pair of inseparable diastereomers 23 (49 $\mathrm{mg}, 89 \%$, $\mathrm{dr}$ 4.0:1).

The major isomer: ${ }^{1} \mathbf{H}$ NMR $\left(400 \mathrm{MHz}, \mathrm{CDCl}_{3}\right) \delta 4.49(\mathrm{t}, J=1.8 \mathrm{~Hz}, 1 \mathrm{H}), 3.64(\mathrm{~d}$, $J=5.6 \mathrm{~Hz}, 2 \mathrm{H}), 3.22(\mathrm{dt}, J=6.8,2.2 \mathrm{~Hz}, 1 \mathrm{H}), 2.74-2.63(\mathrm{~m}, 1 \mathrm{H}), 2.59-2.50$ (m, 1 
H), 2.25-2.08 (m, $3 \mathrm{H}), 1.95-1.85(\mathrm{~m}, 1 \mathrm{H}), 1.75(\mathrm{t}, J=2.2 \mathrm{~Hz}, 3 \mathrm{H}), 1.18(\mathrm{~s}, 3 \mathrm{H})$, 1.00 (s, $3 \mathrm{H}), 0.89$ (s, $9 \mathrm{H}), 0.041$ (s, $6 \mathrm{H}) ;{ }^{13} \mathbf{C}$ NMR (100 MHz, $\left.\mathrm{CDCl}_{3}\right) \delta 178.3,85.9$, 84.9, 78.3, 62.6, 62.2, 60.1, 56.6, 46.2, 40.9, 25.9, 25.1, 24.9, 23.8, 18.2, 16.2, 3.4, $-5.3,-5.4$; HRMS (ESI) calcd for $\mathrm{C}_{21} \mathrm{H}_{35} \mathrm{O}_{3} \mathrm{Si}[\mathrm{M}+\mathrm{H}]^{+} 363.2350$, found 363.2346.
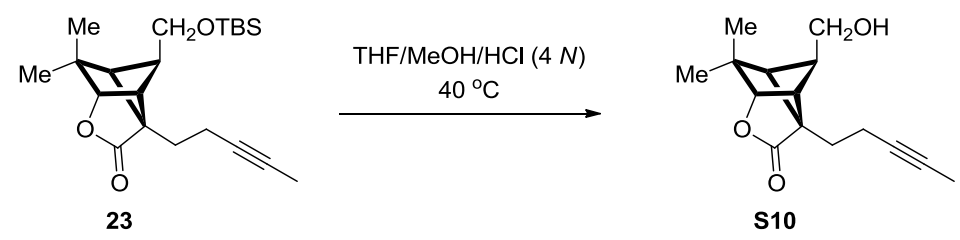

Hydrochloric acid ( $4 \mathrm{~N}, 1.0 \mathrm{~mL})$ was added to a solution of $23(29 \mathrm{mg}, 0.080 \mathrm{mmol}$, 1.0 equiv) in THF $(1.0 \mathrm{~mL})$ and $\mathrm{MeOH}(1.0 \mathrm{~mL})$ and the resulting mixture was stirred at $40{ }^{\circ} \mathrm{C}$ overnight. After cooling to room temperature, the mixture was extracted with EtOAc. The combined organic layer was washed with brine, dried over $\mathrm{Na}_{2} \mathrm{SO}_{4}$ and concentrated. The residue was purified by column chromatography on silica gel $(20 \%$ EtOAc in hexanes) to afford a pair of inseparable diastereomers $\mathbf{S 1 0}$ (23 $\mathrm{mg}, 85 \%$, dr 4.0:1).

The major isomer: ${ }^{1} \mathbf{H}$ NMR $\left(400 \mathrm{MHz}, \mathrm{CDCl}_{3}\right) \delta 4.50(\mathrm{t}, J=2.0 \mathrm{~Hz}, 1 \mathrm{H}), 3.70$ $(\mathrm{d}, J=5.6 \mathrm{~Hz}, 2 \mathrm{H}), 3.33-3.25(\mathrm{~m}, 1 \mathrm{H}), 2.75-2.64(\mathrm{~m}, 1 \mathrm{H}), 2.60-2.54(\mathrm{~m}, 1 \mathrm{H})$, 2.35-2.08 (m, $3 \mathrm{H}), 1.97-1.85(\mathrm{~m}, 1 \mathrm{H}), 1.84$ (br s, $1 \mathrm{H})$ 1.77-1.69 (m, $3 \mathrm{H}), 1.15$ (s, 3 $\mathrm{H}), 1.00$ (s, $3 \mathrm{H}) ;{ }^{13} \mathrm{C}$ NMR (100 MHz, $\left.\mathrm{CDCl}_{3}\right) \delta 178.3,85.7,78.2,76.3,62.6,62.3$, 60.3, 56.6, 46.4, 40.8, 25.0, 24.8, 23.9, 16.2, 3.4; HRMS (ESI) calcd for $\mathrm{C}_{15} \mathrm{H}_{20} \mathrm{O}_{3} \mathrm{Na}$ $[\mathrm{M}+\mathrm{Na}]^{+} 271.1310$, found 271.1308 .

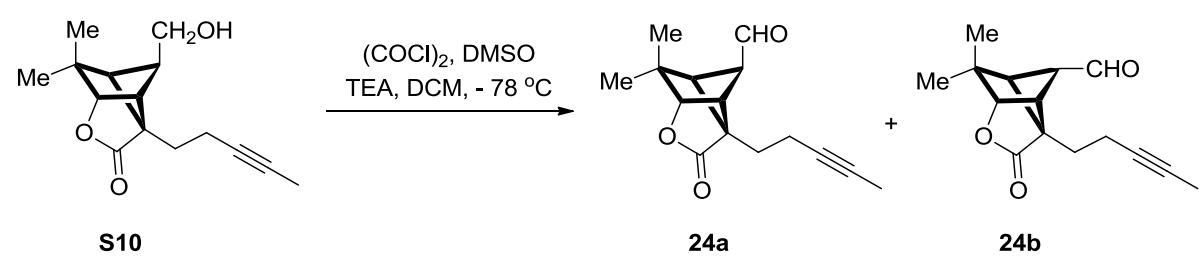

Dimethyl sulfoxide (110 $\mu \mathrm{L}, 1.49 \mathrm{mmol}, 16.0$ equiv) was added slowly to a solution of $(\mathrm{COCl})_{2}(63 \mu \mathrm{L}, 0.74 \mathrm{mmol}, 8.0$ equiv $)$ in $\mathrm{DCM}(2 \mathrm{~mL})$ at $-78{ }^{\circ} \mathrm{C}$ and stirred for $45 \mathrm{~min}$. Alcohol S10 (23 mg, $0.090 \mathrm{mmol}, 1.0$ equiv) in DCM (1 mL) was added and stirred for $2.5 \mathrm{~h}$. Subsequently $\mathrm{Et}_{3} \mathrm{~N}(0.26 \mathrm{~mL}, 1.86 \mathrm{mmol}, 20.0$ equiv) was added and stirred for additional $2 \mathrm{~h}$ at $-78{ }^{\circ} \mathrm{C}$ and room temperature for $20 \mathrm{~min}$. Water was added and the mixture was extracted with DCM. The combined organic layer was washed with brine, dried over $\mathrm{Na}_{2} \mathrm{SO}_{4}$ and concentrated. The residue was purified by column chromatography on silica gel (20\% EtOAc in hexanes) to give $\mathbf{2 4 a}$ (13 $\mathrm{mg}$, $57 \%$ ) and $\mathbf{2 4 b}$ (9 $\mathrm{mg}, 39 \%)$.

24a, less polar (Rf. 0.50, 25\% EtOAc in hexanes): ${ }^{1} \mathbf{H}$ NMR $\left(400 \mathrm{MHz}, \mathrm{CDCl}_{3}\right) \delta$ $9.84(\mathrm{~s}, 1 \mathrm{H}), 4.55(\mathrm{t}, J=1.8 \mathrm{~Hz}, 1 \mathrm{H}), 3.52(\mathrm{dt}, J=6.8,2.2 \mathrm{~Hz}, 1 \mathrm{H}), 3.08(\mathrm{t}, J=2.6$ $\mathrm{Hz}, 1 \mathrm{H}), 3.02-2.95(\mathrm{~m}, 1 \mathrm{H}), 2.36-2.24(\mathrm{~m}, 1 \mathrm{H}), 2.23-2.10$ (m, $2 \mathrm{H}), 1.94-1.80$ (m, 1 $\mathrm{H}), 1.73(\mathrm{t}, J=2.4 \mathrm{~Hz}, 3 \mathrm{H}), 1.04(\mathrm{~s}, 3 \mathrm{H}), 1.03(\mathrm{~s}, 3 \mathrm{H}) ;{ }^{13} \mathrm{C} \mathrm{NMR}\left(100 \mathrm{MHz}, \mathrm{CDCl}_{3}\right)$ $\delta$ 201.5, 177.0, 84.0, 78.0, 62.3, 59.2, 53.5, 53.1, 41.1, 25.3, 24.7, 23.5, 16.0, 3.3; HRMS (ESI) calcd for $\mathrm{C}_{15} \mathrm{H}_{18} \mathrm{O}_{3} \mathrm{Na}[\mathrm{M}+\mathrm{Na}]^{+}$269.1154, found 269.1155. 
24b, more polar (Rf. 0.42, 25\% EtOAc in hexanes): ${ }^{1} \mathbf{H}$ NMR (400 MHz, $\mathrm{CDCl}_{3}$ ) $\delta 10.24(\mathrm{~s}, 1 \mathrm{H}), 4.50(\mathrm{~s}, 1 \mathrm{H}), 3.54(\mathrm{~d}, J=6.8 \mathrm{~Hz}, 1 \mathrm{H}), 2.88(\mathrm{~s}, 1 \mathrm{H}), 2.79(\mathrm{~d}, J=7.2$, $\mathrm{Hz}, 1 \mathrm{H}), 2.28-2.08(\mathrm{~m}, 3 \mathrm{H}), 1.74(\mathrm{~s}, 4 \mathrm{H}), 1.21(\mathrm{~s}, 3 \mathrm{H}), 1.09(\mathrm{~s}, 3 \mathrm{H}) ;{ }^{13} \mathbf{C}$ NMR $\left(100 \mathrm{MHz}, \mathrm{CDCl}_{3}\right) \delta 199.9,176.9,83.8,77.8,76.8,62.6,58.6,55.1,52.7,42.0,25.9$, 23.2, 22.7, 15.1, 3.4; HRMS (ESI) calcd for $\mathrm{C}_{15} \mathrm{H}_{18} \mathrm{O}_{3} \mathrm{Na}[\mathrm{M}+\mathrm{Na}]^{+}$269.1154, found 269.1152 .
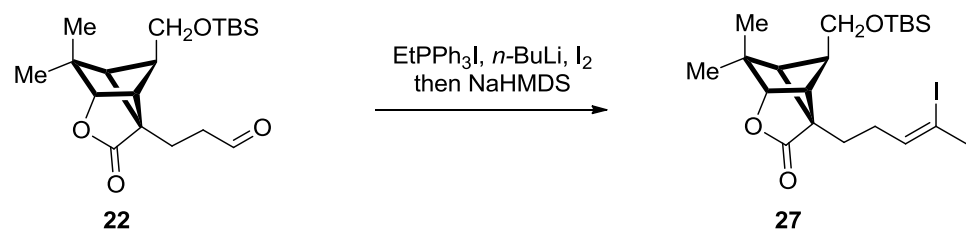

$n$-Butyllithium (2.4 $M$ in THF, $0.15 \mathrm{ml}, 0.36 \mathrm{mmol}, 3.6$ equiv) was added slowly to a suspension of ethyltriphenylphosphonium iodide $(0.150 \mathrm{~g}, 0.36 \mathrm{mmol}, 3.6$ equiv) in THF $(1 \mathrm{~mL})$ at $0{ }^{\circ} \mathrm{C}$ and and stirred at room temperature for $30 \mathrm{~min}$. The orange solution was dropped to a solution of iodine ( $91 \mathrm{mg}, 0.36 \mathrm{mmol}, 3.6$ equiv) in THF (1 $\mathrm{mL})$ at $-78{ }^{\circ} \mathrm{C}$ via cannula and stirred for $0.5 \mathrm{~h}$ before NaHMDS ( $0.15 \mathrm{~mL}, 3.0$ equiv) was added. After stirring for $30 \mathrm{~min}$, aldehyde 22 (36 mg, $0.10 \mathrm{mmol}, 1.0$ equiv) in THF $(0.5 \mathrm{~mL})$ was added and stirred for $6 \mathrm{~h}$. Diethyl ether was added and and solid was filtered off through a pad of celite, washed with $\mathrm{Et}_{2} \mathrm{O}$ and concentrated. The residue was purified by column chromatography on silica gel (1\% EtOAc in hexanes) to give a pair of inseparable diastereomers 27 (24 mg, 50\%, $\mathrm{dr} 4.2: 1)$.

The major isomer: ${ }^{1} \mathbf{H}$ NMR $\left(400 \mathrm{MHz}, \mathrm{CDCl}_{3}\right) \delta 5.47(\mathrm{t}, J=6.2 \mathrm{~Hz}, 1 \mathrm{H}), 4.50(\mathrm{~s}$, $1 \mathrm{H}), 3.65(\mathrm{~d}, J=5.6 \mathrm{~Hz}, 2 \mathrm{H}), 3.20-3.10(\mathrm{~m}, 1 \mathrm{H}), 2.71-2.60(\mathrm{~m}, 1 \mathrm{H}), 2.52(\mathrm{~d}, J=$ $6.9 \mathrm{~Hz}, 1 \mathrm{H}), 2.48$ (s, $3 \mathrm{H}), 2.15-1.95(\mathrm{~m}, 3 \mathrm{H}), 1.82-1.70(\mathrm{~m}, 1 \mathrm{H}), 1.17$ (s, $3 \mathrm{H}), 1.01$ $(\mathrm{s}, 3 \mathrm{H}), 0.89$ (s, $9 \mathrm{H}), 0.05$ (s, $6 \mathrm{H}) ;{ }^{13} \mathbf{C} \mathbf{N M R}\left(100 \mathrm{MHz}, \mathrm{CDCl}_{3}\right) \delta$ 178.5, 134.2, 102.0, 85.9, 62.64, 62.61, 60.1, 56.6, 46.5, 40.9, 34.0, 33.4, 25.9, 25.1, 23.9, 23.8, 18.2, -5.2, -5.3; HRMS (ESI) calcd for $\mathrm{C}_{21} \mathrm{H}_{36} \mathrm{O}_{3} \mathrm{ISi}[\mathrm{M}+\mathrm{H}]^{+} 491.1473$, found 491.1478 .
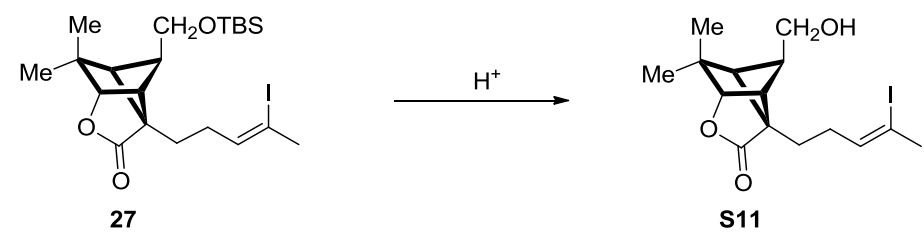

Hydrochloric acid (4 N, $2.0 \mathrm{~mL}$ ) was added to a solution of 27 (24 mg, 0.050 mmol, 1.0 equiv) in THF $(1.5 \mathrm{~mL})$ and $\mathrm{MeOH}(1.5 \mathrm{~mL})$ and the resulting mixture was stirred at $40{ }^{\circ} \mathrm{C}$ overnight. After cooling to room temperature, the mixture was extracted with EtOAc three times. The combined organic layer was washed with brine, dried over $\mathrm{Na}_{2} \mathrm{SO}_{4}$ and concentrated. The residue was purified by column chromatography on silica gel (20\% EtOAc in hexanes) to afford a pair of inseparable diastereomers S11 (18 mg, 98\%, dr 4.2:1).

The major isomer: ${ }^{1} \mathbf{H}$ NMR $\left(400 \mathrm{MHz}, \mathrm{CDCl}_{3}\right) \delta 5.52-5.45(\mathrm{~m}, 1 \mathrm{H}), 4.52(\mathrm{t}, J=$ $2.0 \mathrm{~Hz}, 1 \mathrm{H}), 3.73(\mathrm{~d}, J=5.2 \mathrm{~Hz}, 2 \mathrm{H}), 3.20(\mathrm{dt}, J=7.0,2.0 \mathrm{~Hz}, 1 \mathrm{H}), 2.70-2.63(\mathrm{~m}, 1$ 
H), 2.62-2.56 (m, $1 \mathrm{H}), 2.45-2.51(\mathrm{~m}, 3 \mathrm{H}), 2.17-1.98(\mathrm{~m}, 3 \mathrm{H}), 1.85-1.73(\mathrm{~m}, 1 \mathrm{H})$, 1.17 (s, $3 \mathrm{H}), 1.02$ (s, $3 \mathrm{H}) ;{ }^{13} \mathrm{C}$ NMR $\left(100 \mathrm{MHz}, \mathrm{CDCl}_{3}\right) \delta 178.4,134.1,102.1,85.7$, 62.65, 62.59, 56.5, 46.5, 40.9, 34.0, 33.4, 25.0, 23.91, 23.86, 23.2; HRMS (ESI) calcd for $\mathrm{C}_{15} \mathrm{H}_{22} \mathrm{O}_{3} \mathrm{I}[\mathrm{M}+\mathrm{H}]^{+}$377.0608, found 377.0613.

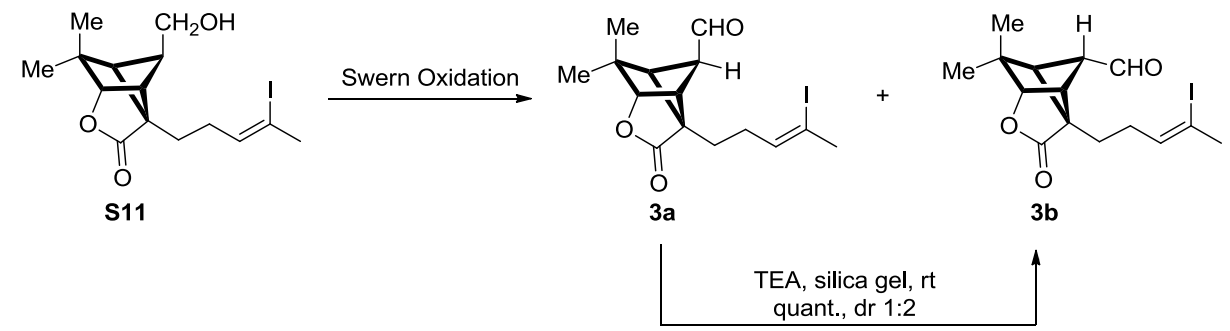

Dimethyl sulfoxide (19 $\mu \mathrm{L}, 0.27 \mathrm{mmol}, 6$ equiv) was slowly added to a solution of $(\mathrm{COCl})_{2}(15 \mu \mathrm{L}, 0.18 \mathrm{mmol}, 4$ equiv $)$ in $\mathrm{DCM}(2 \mathrm{~mL})$ at $-78^{\circ} \mathrm{C}$ and stirred for $45 \mathrm{~min}$. Alcohol S11 (17 mg, $0.045 \mathrm{mmol}, 1.0$ equiv) in DCM (1 mL) was added and stirred for $2.5 \mathrm{~h}$. Subsequently $\mathrm{Et}_{3} \mathrm{~N}(50 \mu \mathrm{L}, 0.36 \mathrm{mmol}, 8.0$ equiv) was added and stirred at $-78{ }^{\circ} \mathrm{C}$ for $2 \mathrm{~h}$, room temperature for $20 \mathrm{~min}$. Water was added and the mixture was extracted with DCM. The combined organic layer was washed with brine, dried over $\mathrm{Na}_{2} \mathrm{SO}_{4}$ and concentrated. The residue was purified by column chromatography on silica with 20\% EtOAc in hexanes to give 3a (9 mg, 53\%) and $\mathbf{3 b}(7 \mathrm{mg}, 41 \%)$.

3a, less polar (Rf. 0.56, 25\% EtOAc in hexanes): ${ }^{1} \mathbf{H}$ NMR $\left(400 \mathrm{MHz}, \mathrm{CDCl}_{3}\right) \delta$ $9.84(\mathrm{~s}, 1 \mathrm{H}), 5.48(\mathrm{td}, J=6.8,1.3 \mathrm{~Hz}, 1 \mathrm{H}), 4.57$ (t, $J=1.8 \mathrm{~Hz}, 1 \mathrm{H}), 3.37$ (dt, $J=6.8$, $2.0 \mathrm{~Hz}, 1 \mathrm{H}), 3.03(\mathrm{t}, J=2.6 \mathrm{~Hz}, 1 \mathrm{H}), 3.01-2.96(\mathrm{~m}, 1 \mathrm{H}), 2.49$ (s, $3 \mathrm{H}), 2.18-1.96(\mathrm{~m}$, $3 \mathrm{H}), 1.83-1.69$ (m, $1 \mathrm{H}), 1.042$ (s, $3 \mathrm{H}), 1.039$ (s, $3 \mathrm{H}) ;{ }^{13} \mathbf{C ~ N M R}\left(100 \mathrm{MHz}, \mathrm{CDCl}_{3}\right)$ $\delta$ 201.5, 177.1, 133.6, 102.7, 84.1, 62.6, 59.1, 53.6, 53.0, 41.2, 33.7, 33.4, 25.3, 23.8, 23.5; HRMS (ESI) calcd for $\mathrm{C}_{15} \mathrm{H}_{20} \mathrm{O}_{3} \mathrm{I}[\mathrm{M}+\mathrm{H}]^{+} 375.0452$, found 375.0454 .

3b, more polar (Rf. 0.48, 25\% EtOAc in hexanes): ${ }^{\mathbf{1}} \mathbf{H}$ NMR $\left(400 \mathrm{MHz}, \mathrm{CDCl}_{3}\right) \delta$ 10.23 (s, $1 \mathrm{H}), 5.43-5.33$ (m, $1 \mathrm{H}), 4.50$ (s, $1 \mathrm{H}), 3.47$ (dd, $J=7.2,2.4 \mathrm{~Hz}, 1 \mathrm{H}), 2.89$ (s, $1 \mathrm{H}), 2.75(\mathrm{dd}, J=7.2,1.6 \mathrm{~Hz}, 1 \mathrm{H}), 2.47$ (s, $3 \mathrm{H}), 2.18-195(\mathrm{~m}, 4 \mathrm{H}), 1.22(\mathrm{~s}, 3 \mathrm{H})$, 1.09 (s, $3 \mathrm{H}) ;{ }^{13} \mathrm{C}$ NMR $\left(100 \mathrm{MHz}, \mathrm{CDCl}_{3}\right) \delta 199.8,177.1,133.8,101.8,83.7,62.7$, 58.4, 55.1, 52.8, 42.1, 33.5, 32.9, 25.2, 23.2, 22.7; HRMS (ESI) calcd for $\mathrm{C}_{15} \mathrm{H}_{20} \mathrm{O}_{3} \mathrm{I}$ $[\mathrm{M}+\mathrm{H}]^{+}$375.0452, found 375.0458 .

Comppund 3a $(4 \mathrm{mg})$ was added to a mixture of silica gel $(0.20 \mathrm{~g}), \mathrm{Et}_{3} \mathrm{~N}(0.20 \mathrm{ml})$ and $2 \mathrm{~mL} \mathrm{DCM}$ at room temperature. The resulting mixture was stirred at room temperature overnight and filtered off through a short pad of silica gel (EtOAc) to give a mixture of $\mathbf{3 a}$ and $\mathbf{3 b}$ in 1:2 ratio with quantitative yield. The mixture was separated by column chromatography on silica with $20 \%$ EtOAc in hexanes.

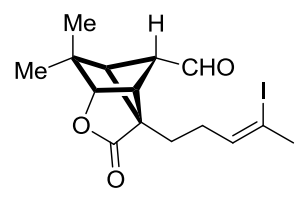

3b
1) $\mathrm{NiCl}_{2}, \mathrm{CrCl}_{2}$, DMSO 2) $(\mathrm{COCl})_{2}, \mathrm{DMSO}, \mathrm{Et}_{3} \mathrm{~N}$

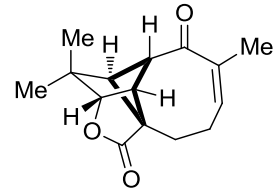

aquatolide (1) 
In glove box, $\mathrm{CrCl}_{2}(52 \mathrm{mg}, 0.423 \mathrm{mmol}, 22.3$ equiv) was added to a mixture of 3 b (7.0 mg, 0.019 mmol, 1.0 equiv, dr 10:1), $\mathrm{NiCl}_{2}$ (0.7 mg, $0.005 \mathrm{mmol}, 28 \mathrm{~mol} \%$ ) and dimethyl sulfoxide $(6.0 \mathrm{~mL})$ and the resulting mixture was stirred at room temperature for 3 days. The mixture was quenched by the addition of water, and extracted with EtOAc. The combined organic layer was washed three times with water, brine, and dried over $\mathrm{Na}_{2} \mathrm{SO}_{4}$ and concentrated. The residue was purified by column chromatography on silica with $20 \%$ EtOAc in hexanes to give $\mathbf{3 b}$ (3.5 mg, $50 \%$, dr 5:1) and crude cyclization product $(3.5 \mathrm{mg}$ ) which was used directly without further purification.

Dimethyl sulfoxide $(80 \mu \mathrm{L}, 1.13 \mathrm{mmol})$ was added slowly to a mixture of $(\mathrm{COCl})_{2}$ $(50 \mu \mathrm{L}, 0.59 \mathrm{mmol})$ in $\mathrm{DCM}(2 \mathrm{~mL})$ at $-78{ }^{\circ} \mathrm{C}$ and stirred at same temperature for 30 min. The above crude cyclization product $(3.5 \mathrm{mg})$ in DCM $(1 \mathrm{~mL})$ was added and stirred for $2.5 \mathrm{~h}$. Subsequently $\mathrm{Et}_{3} \mathrm{~N}(0.30 \mathrm{~mL}, 2.15 \mathrm{mmol})$ was added and stirred at $-78{ }^{\circ} \mathrm{C}$ for $2 \mathrm{~h}$ and room temperature for $20 \mathrm{~min}$. The reaction was quenched by the addition of water, and the mixture was extracted with DCM three times. The combined organic layer was washed with brine, dried over $\mathrm{Na}_{2} \mathrm{SO}_{4}$ and concentrated. The residue was purified by column chromatography on silica gel (10\% EtOAc in hexanes) to give the aquatolide (1) (2.0 mg, $43 \%$ over two steps).

(Rf. 0.59, 25\% EtOAc in hexanes); ${ }^{1} \mathbf{H}$ NMR (400 MHz, $\left.\mathrm{CDCl}_{3}\right) \delta 5.85(\mathrm{~s}, 1 \mathrm{H})$, $4.47(\mathrm{t}, J=2.0 \mathrm{~Hz}, 1 \mathrm{H}), 3.25(\mathrm{dd}, J=7.2,2.4 \mathrm{~Hz}, 1 \mathrm{H}), 2.92(\mathrm{~s}, 1 \mathrm{H}), 2.64(\mathrm{dd}, J=$ 7.2, $1.8 \mathrm{~Hz}, 1 \mathrm{H}), 2.52$ (dd, $J=14.2,7.0 \mathrm{~Hz}, 1 \mathrm{H}), 2.40-2.30$ (m, $1 \mathrm{H}), 2.09-1.92$ (m, 2 $\mathrm{H}), 1.89-1.84(\mathrm{~m}, 3 \mathrm{H}), 1.19(\mathrm{~s}, 3 \mathrm{H}), 1.05(\mathrm{~s}, 3 \mathrm{H})$; In order to compare with the reported data, ${ }^{[1]}$ the ${ }^{13} \mathrm{C} \mathrm{NMR}$ was referenced by the residue of $\mathrm{CDCl}_{3}$ as $77.16 \mathrm{ppm}$, ${ }^{13}$ C NMR (100 MHz, $\left.\mathrm{CDCl}_{3}\right) \delta 211.85,177.47,135.15,131.11,84.24,62.88,62.64$, $54.58,54.48,41.87,28.65,22.86,22.61,22.18,22.18$. HRMS (ESI) calcd for $\mathrm{C}_{15} \mathrm{H}_{19} \mathrm{O}_{3}[\mathrm{M}+\mathrm{H}]^{+} 247.1329$, found 247.1333 .

\section{Reference:}

Michael W. Lodewyk, Cristian Soldi, Paul B. Jones, Marilyn M. Olmstead, Juan Rita, Jared T. Shaw, Dean J. Tantillo. J. Am. Chem. Soc. 2012, 134, 18550. 
Table S1: Comparison of NMR data of Synthetic Aquatolide with Natural Aquatolide

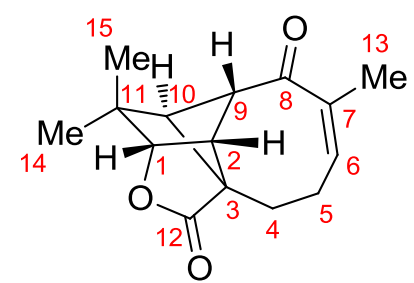

aquatolide (1)

\begin{tabular}{|c|c|c|c|c|}
\hline No. & $\begin{array}{c}\text { Natural aquatolide }^{[1]} \\
\left(\delta{ }^{1} \mathrm{H} \mathrm{ppm}, \mathrm{CDCl}_{3}\right. \\
800 \mathrm{MHz})\end{array}$ & $\begin{array}{c}\text { Synthetic aqutaolide } \\
\left(\delta{ }^{1} \mathrm{H} \mathrm{ppm}, \mathrm{CDCl}_{3},\right. \\
400 \mathrm{MHz})\end{array}$ & $\begin{array}{c}\text { Natural aquatolide }^{[1]} \\
\left(\delta{ }^{13} \mathrm{C} \mathrm{ppm}, \mathrm{CDCl}_{3},\right. \\
200 \mathrm{MHz})\end{array}$ & $\begin{array}{c}\text { Synthetic aquatolide } \\
\left(\delta{ }^{13} \mathrm{C} \mathrm{ppm}, \mathrm{CDCl}_{3},\right. \\
100 \mathrm{MHz})\end{array}$ \\
\hline 1 & 4.48 & 4.47 & 84.20 & 84.24 \\
\hline 2 & 3.26 & 3.25 & 54.54 & 54.58 \\
\hline 3 & & & 62.83 & 62.88 \\
\hline \multirow[t]{2}{*}{4} & 2.52 & 2.52 & 22.15 & 22.18 \\
\hline & 1.96 & 1.96 & & \\
\hline \multirow[t]{2}{*}{5} & 2.35 & 2.35 & 28.63 & 28.65 \\
\hline & 2.03 & 2.03 & & \\
\hline 6 & 5.85 & 5.85 & 131.10 & 131.11 \\
\hline 7 & & & 135.08 & 135.15 \\
\hline 8 & & & 211.94 & 211.85 \\
\hline 9 & 2.92 & 2.92 & 54.45 & 54.48 \\
\hline 10 & 2.64 & 2.64 & 62.59 & 62.64 \\
\hline 11 & & & 41.86 & 41.87 \\
\hline 12 & & & 177.50 & 177.47 \\
\hline 13 & 1.87 & 1.87 & 22.22 & 22.18 \\
\hline 14 & 1.05 & 1.05 & 22.62 & 22.61 \\
\hline 15 & 1.19 & 1.19 & 22.84 & 22.86 \\
\hline
\end{tabular}

\section{Reference:}

[1] Michael W. Lodewyk, Cristian Soldi, Paul B. Jones, Marilyn M. Olmstead, Juan Rita, Jared T. Shaw, Dean J. Tantillo. J. Am. Chem. Soc. 2012, 134, 18550. 


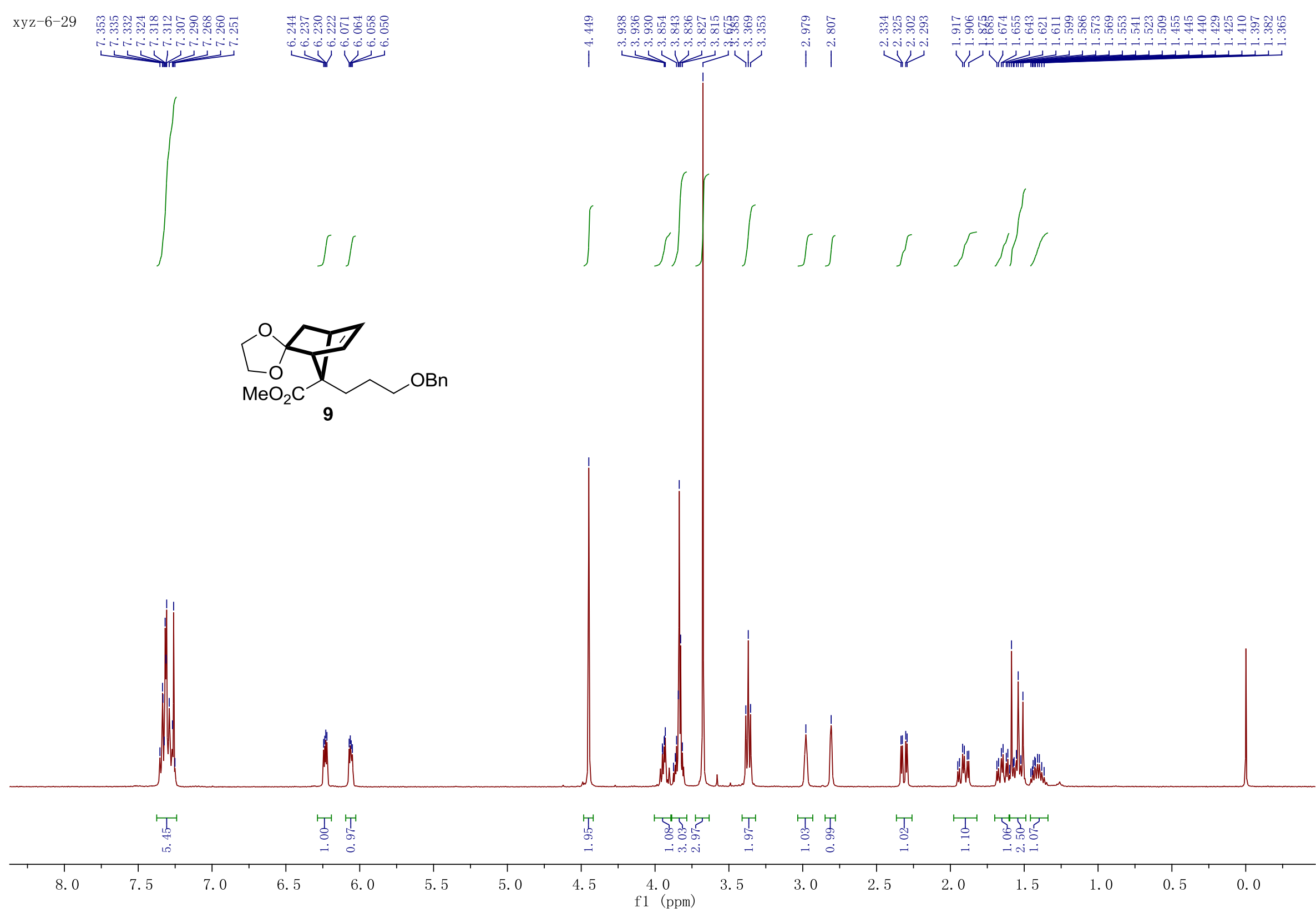


$x y z-6-29 \stackrel{9}{9}$

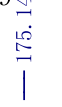

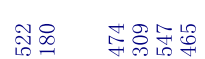

11

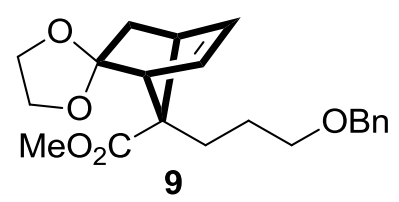

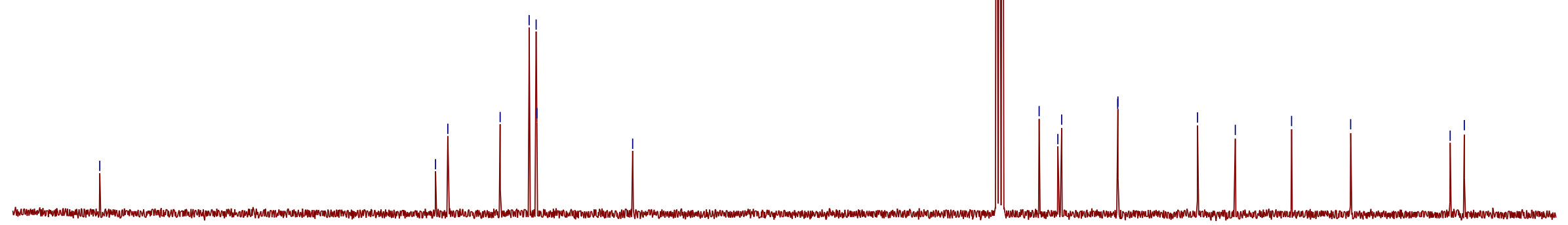

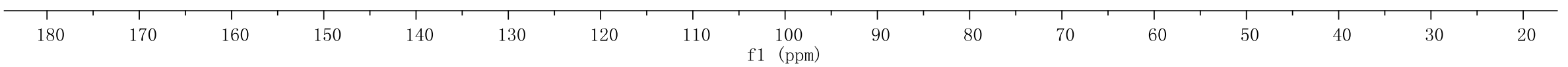




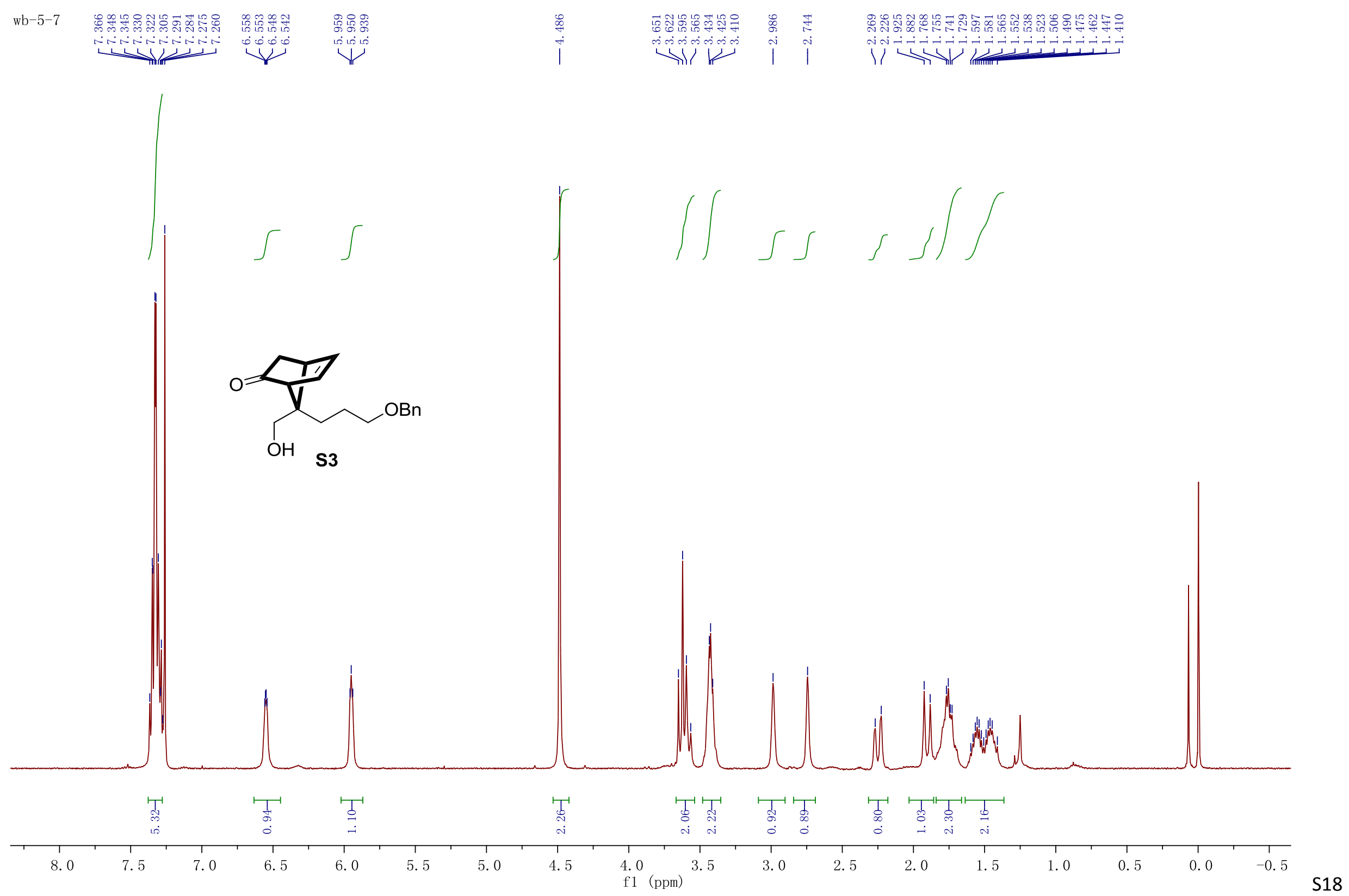



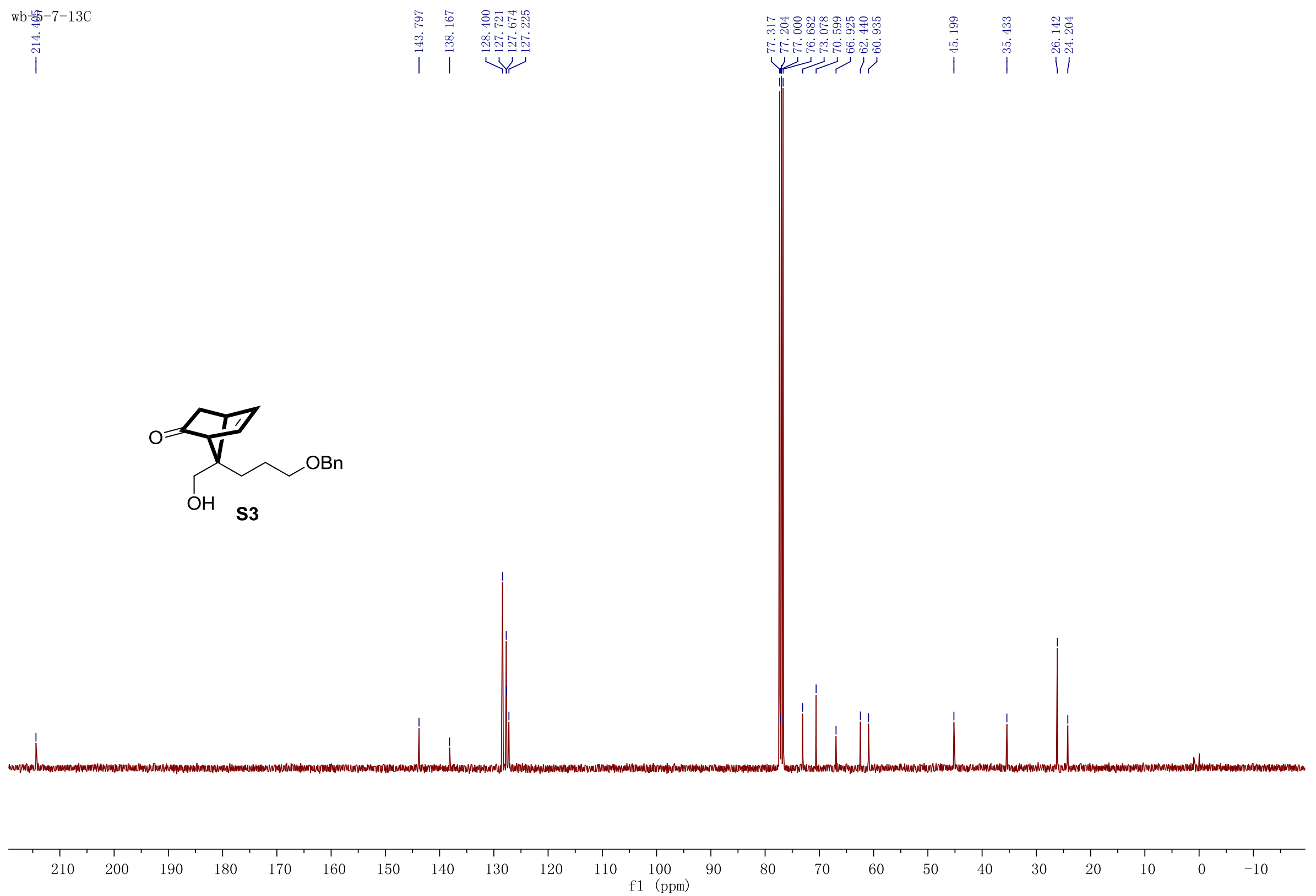


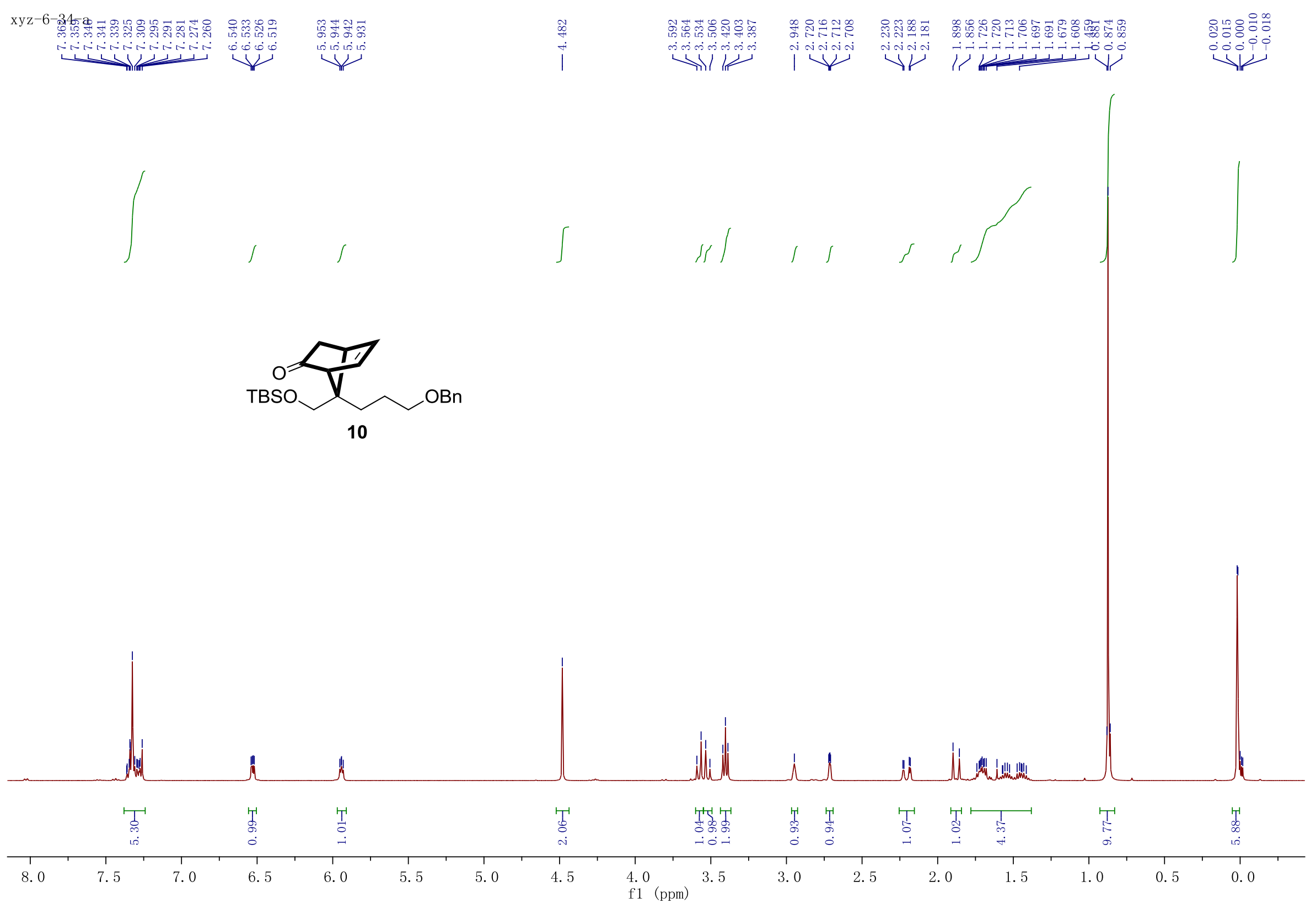



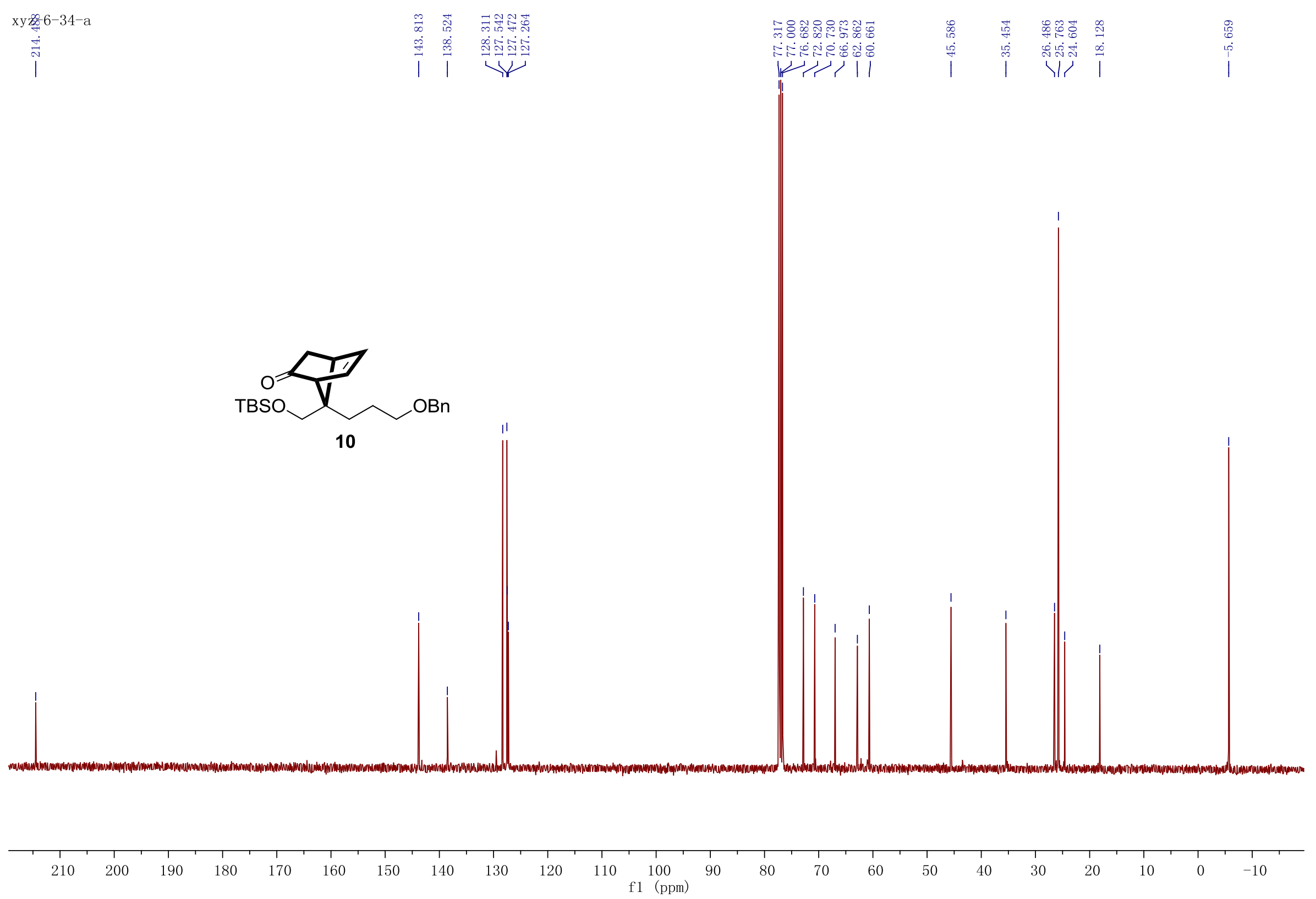


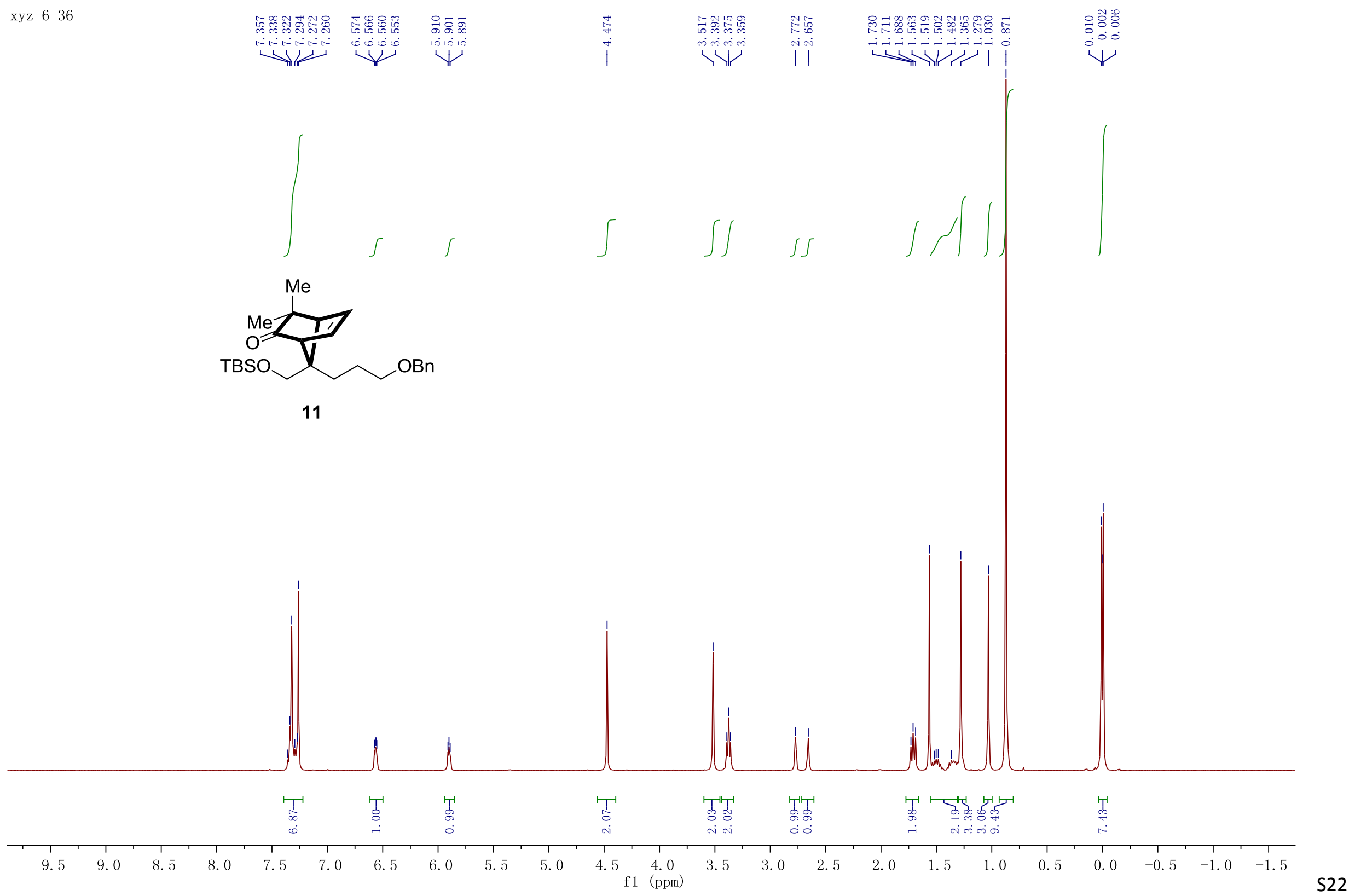




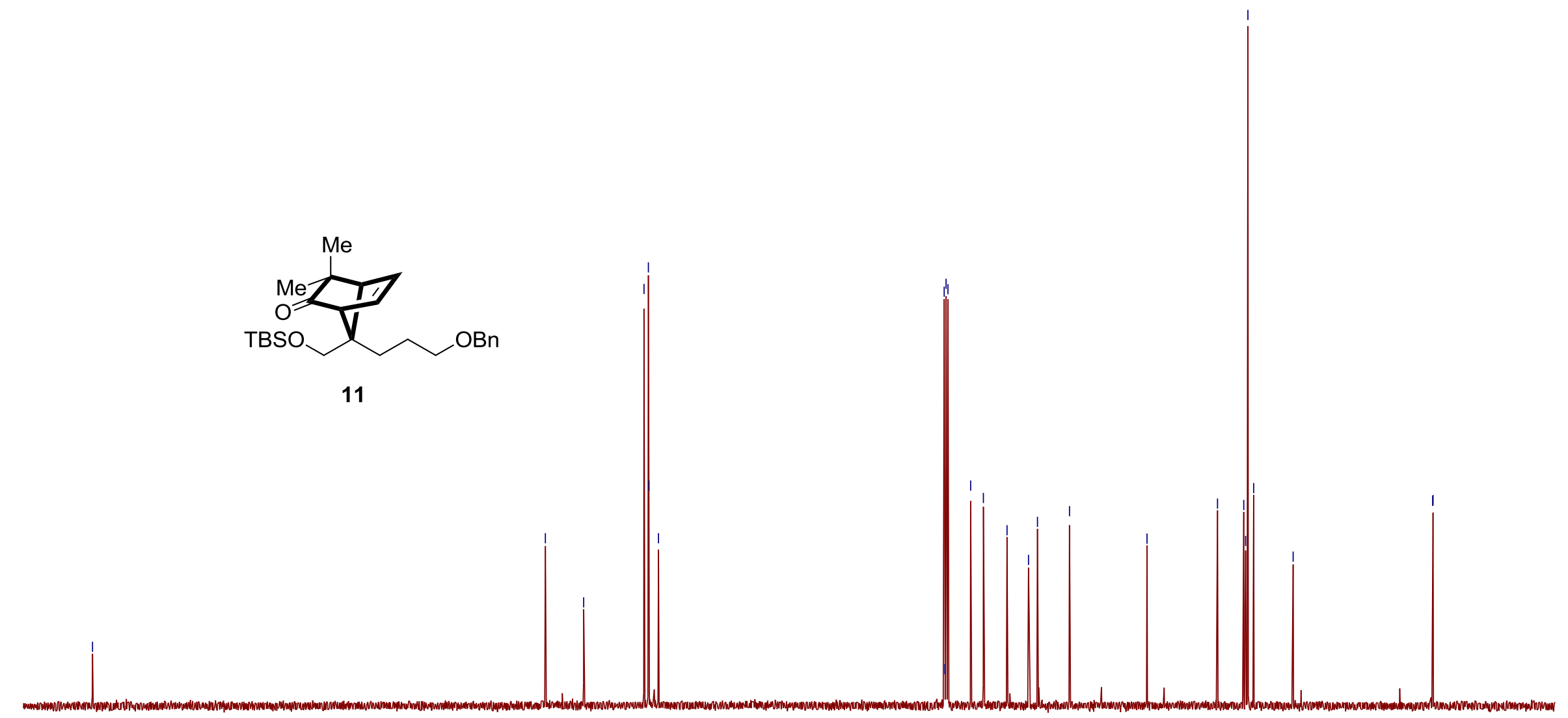




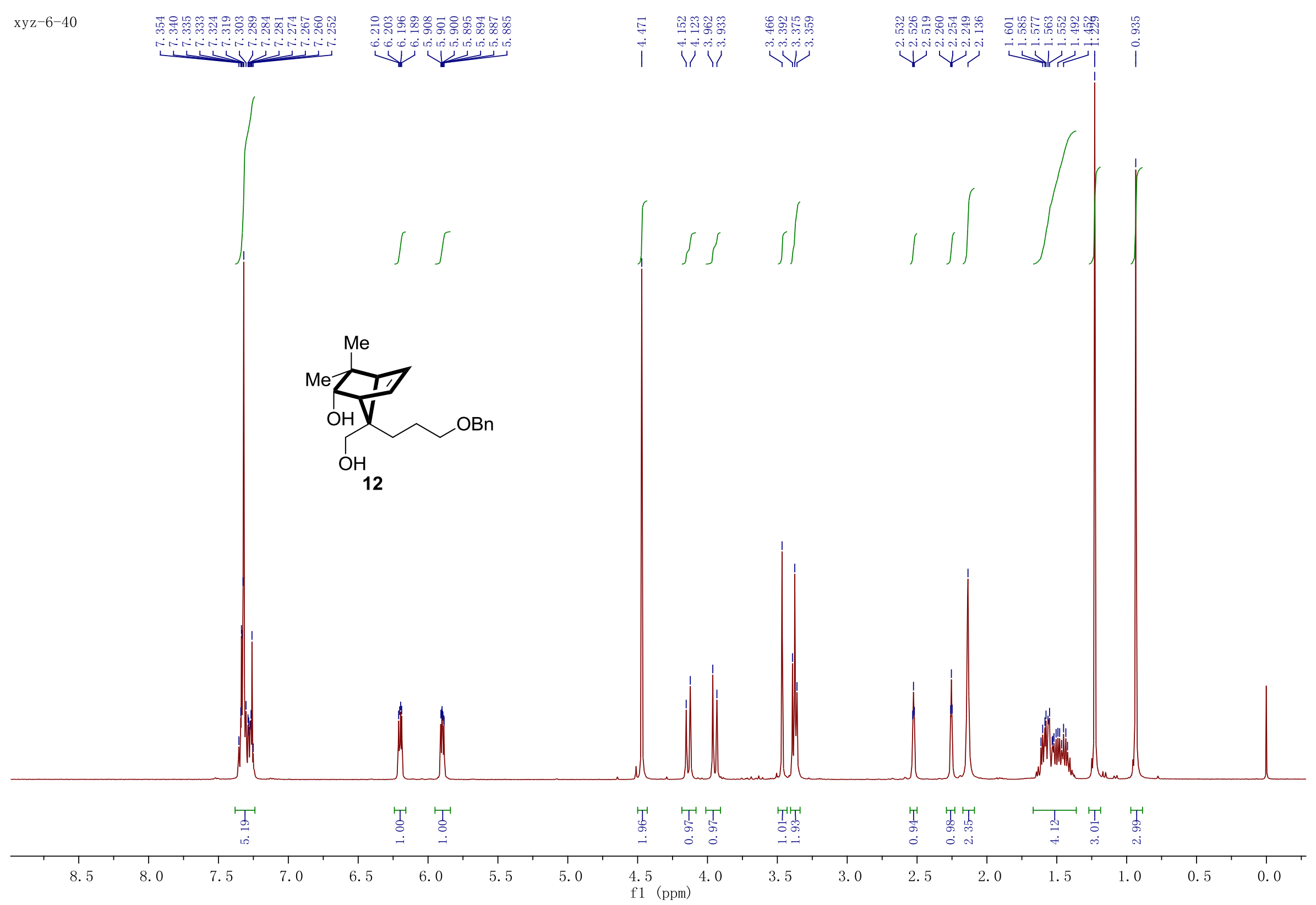



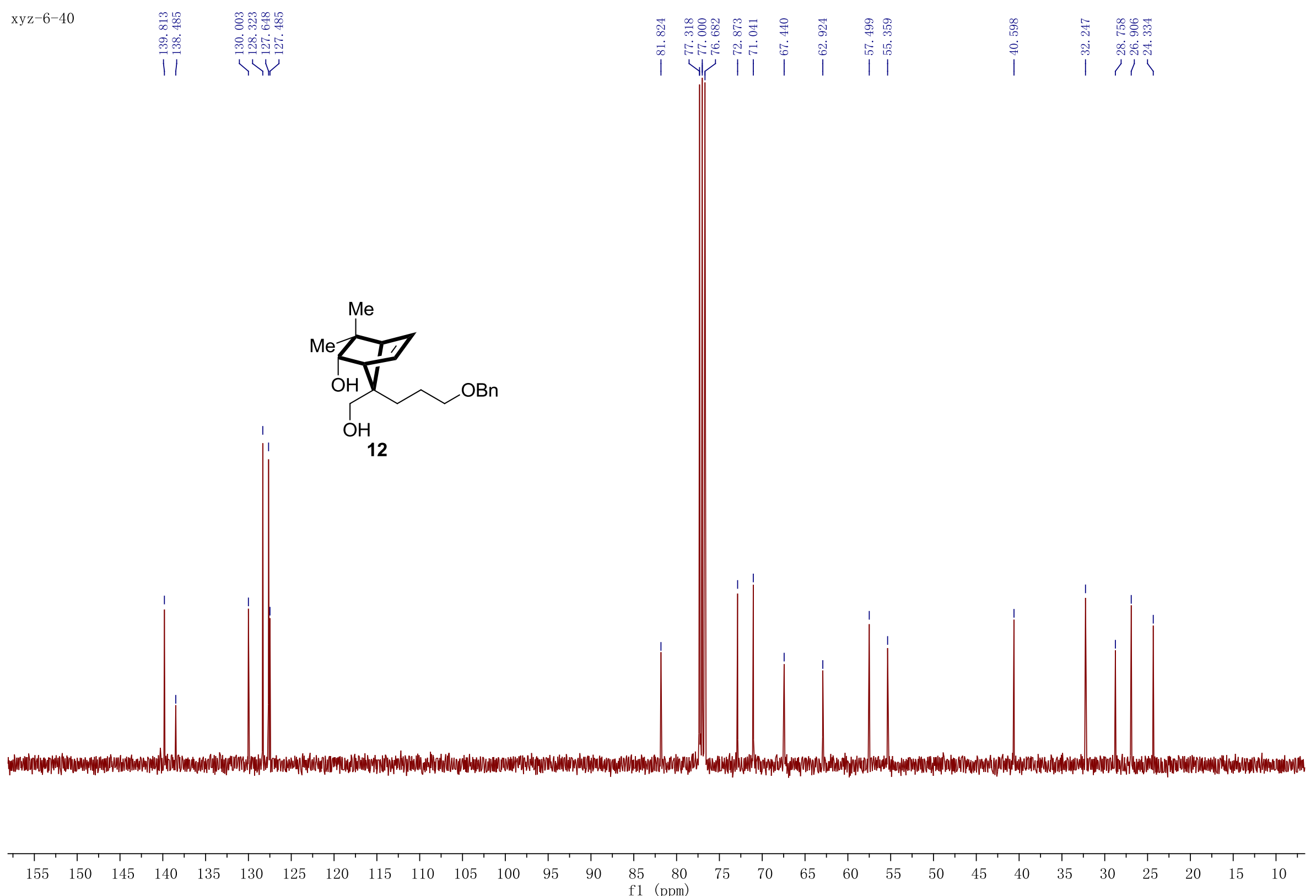


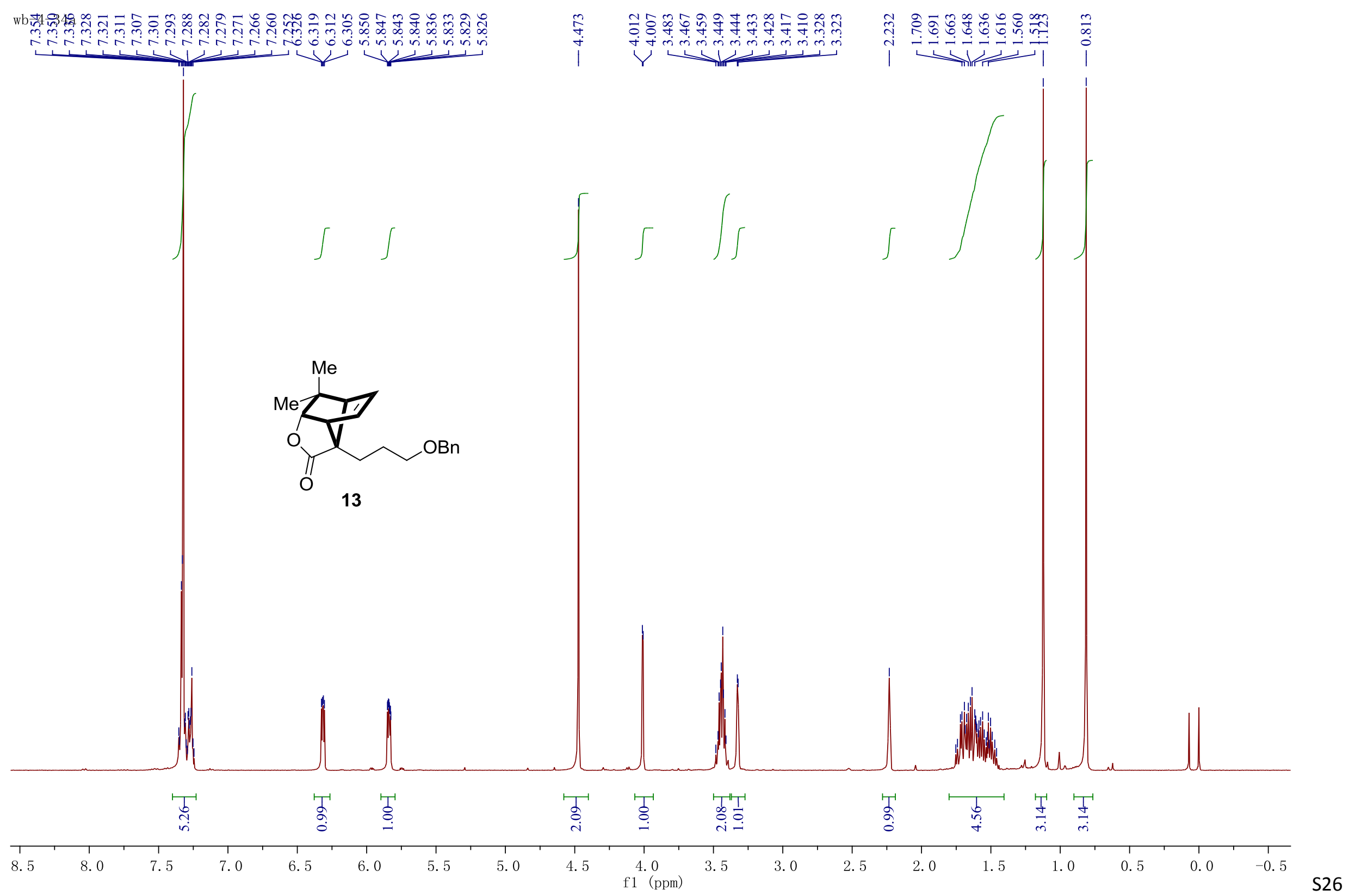


OBn

13

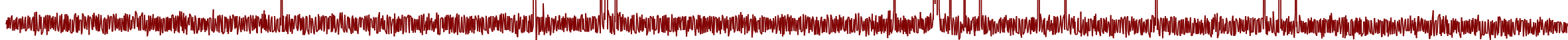

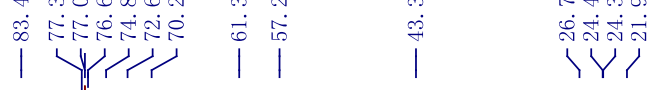
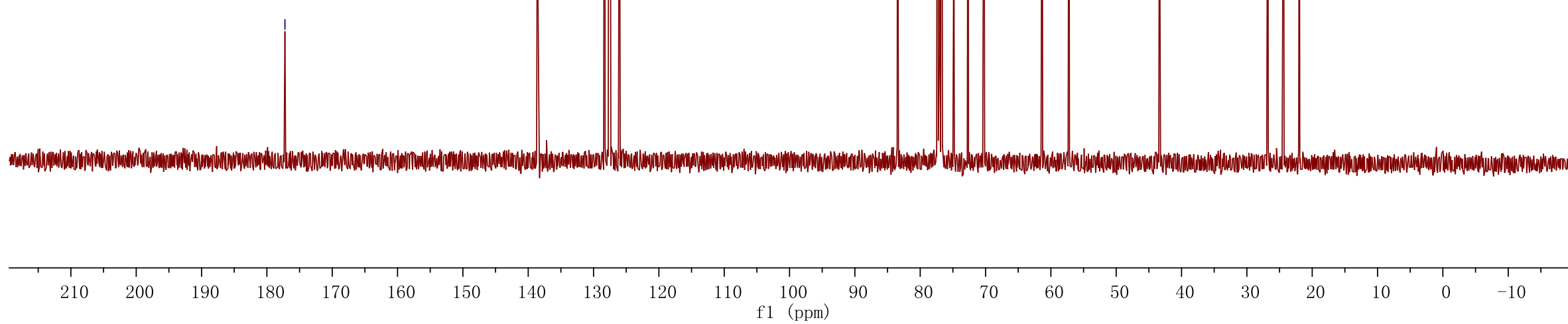


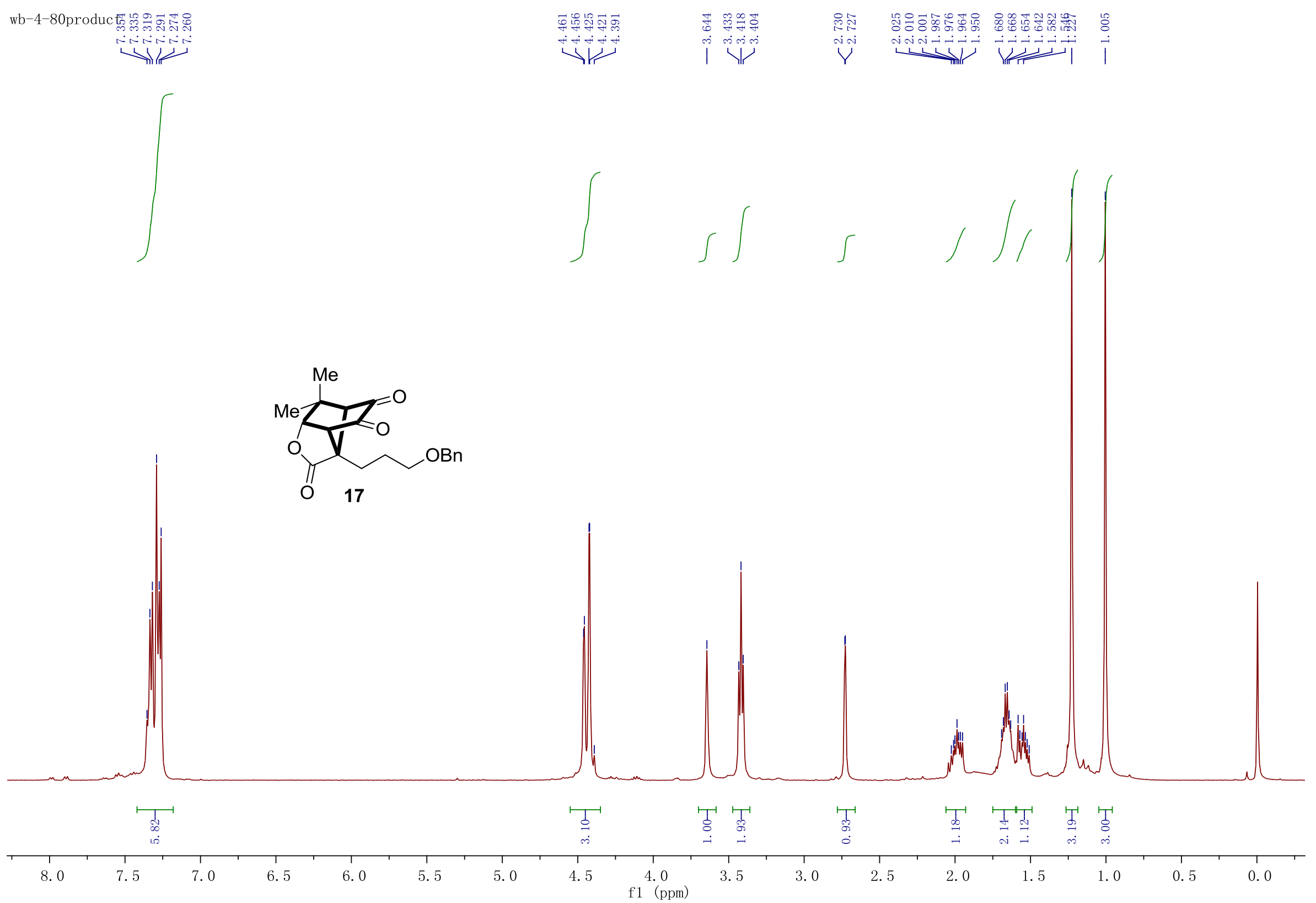



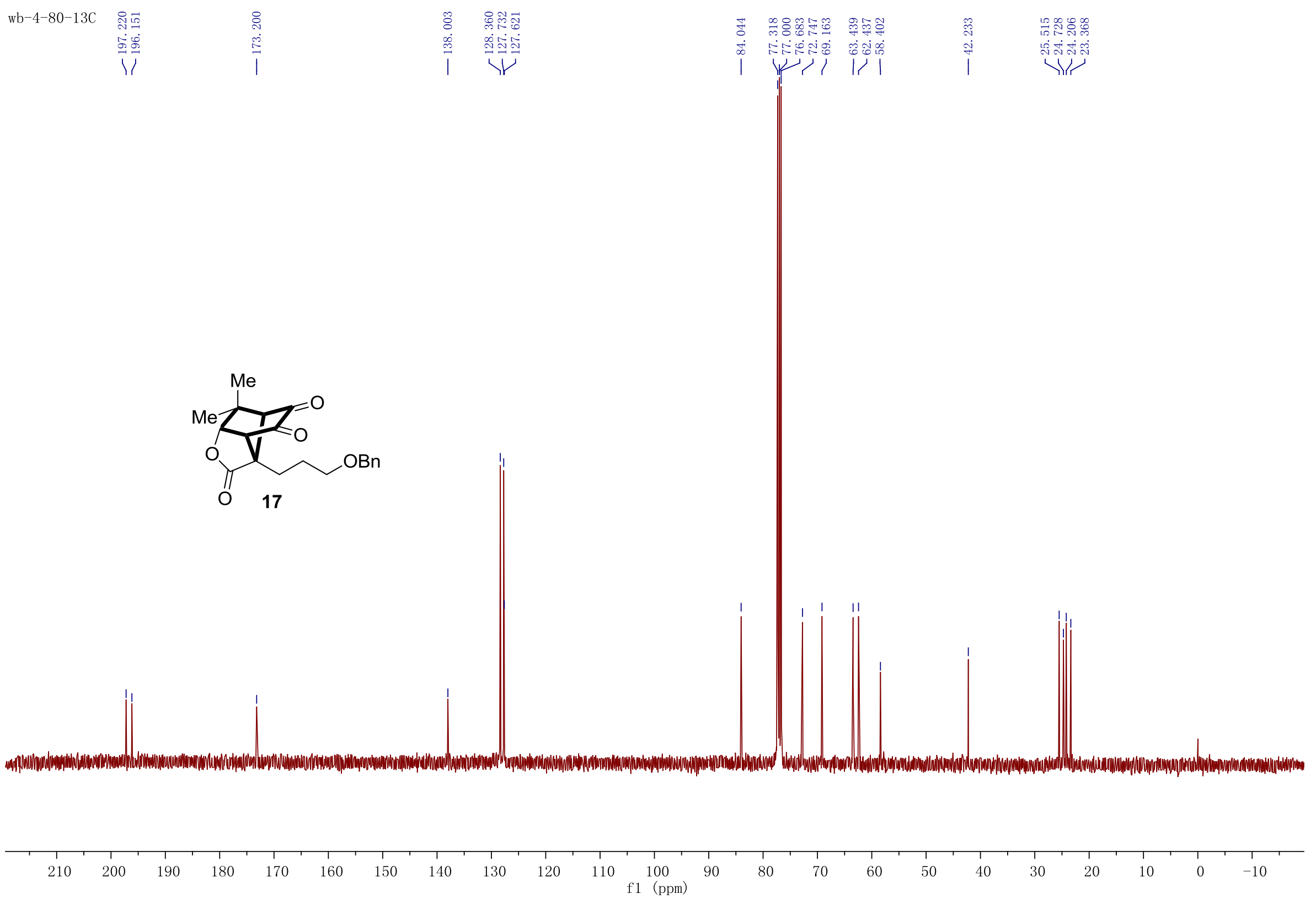


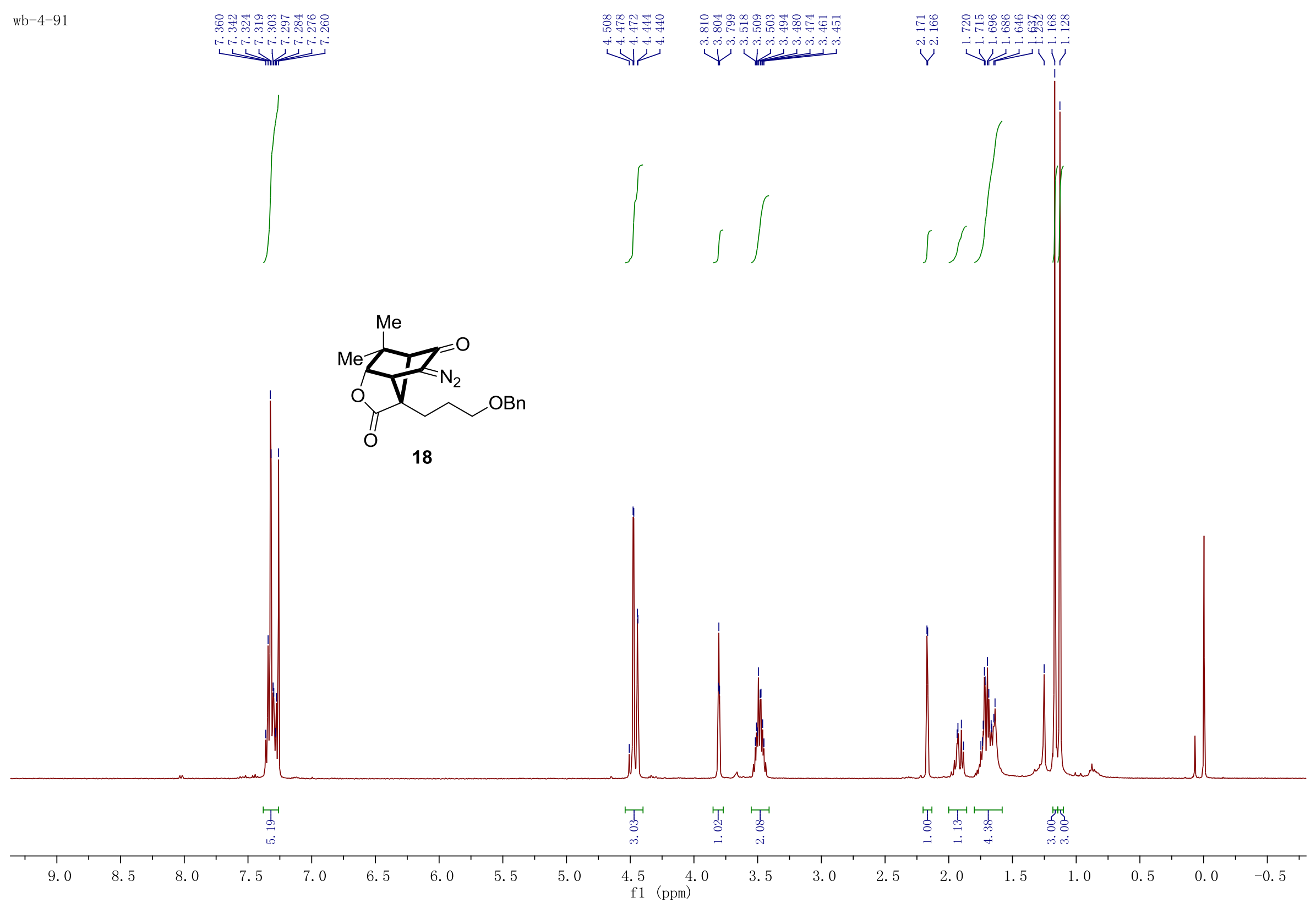




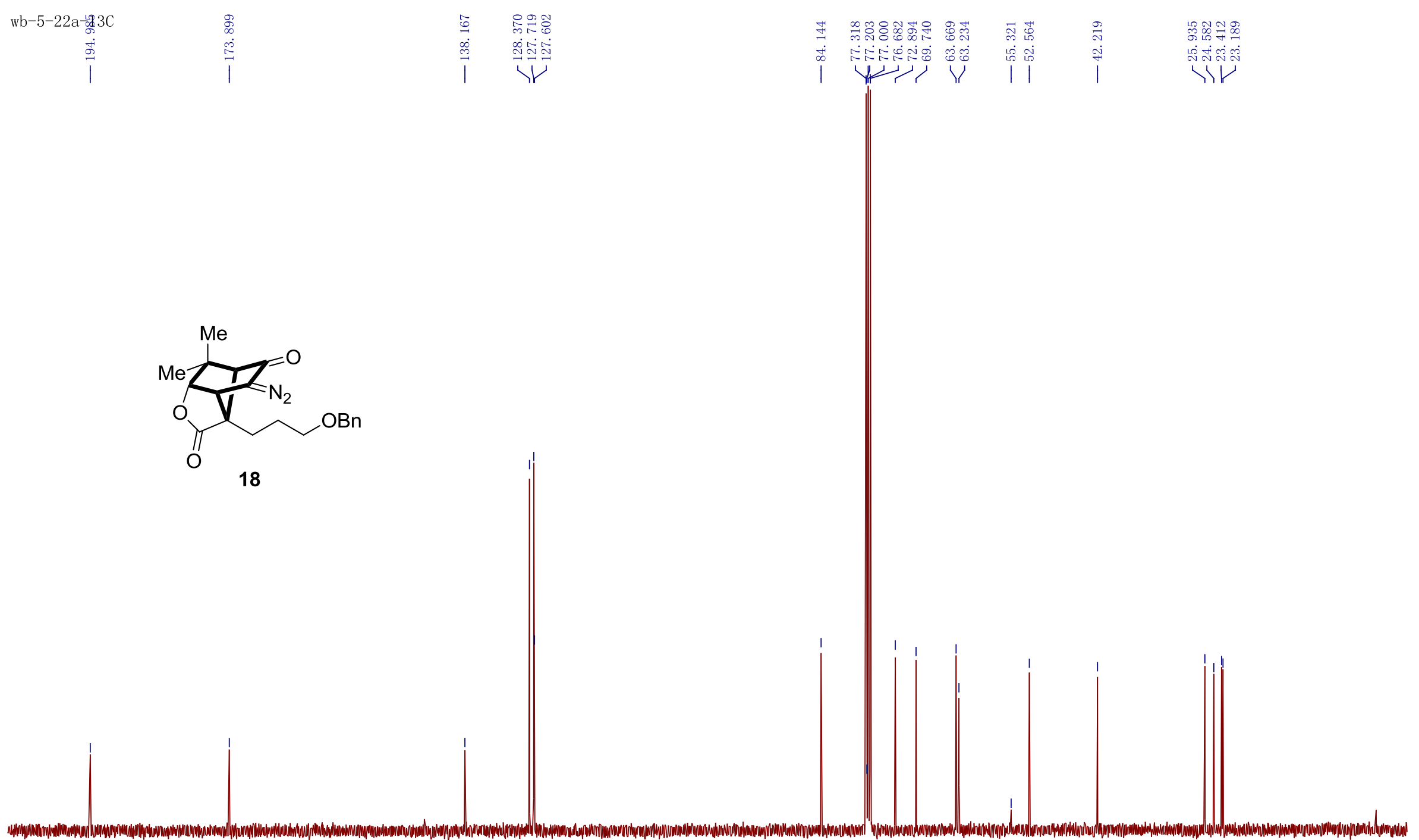

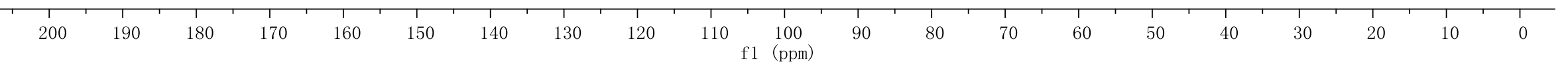




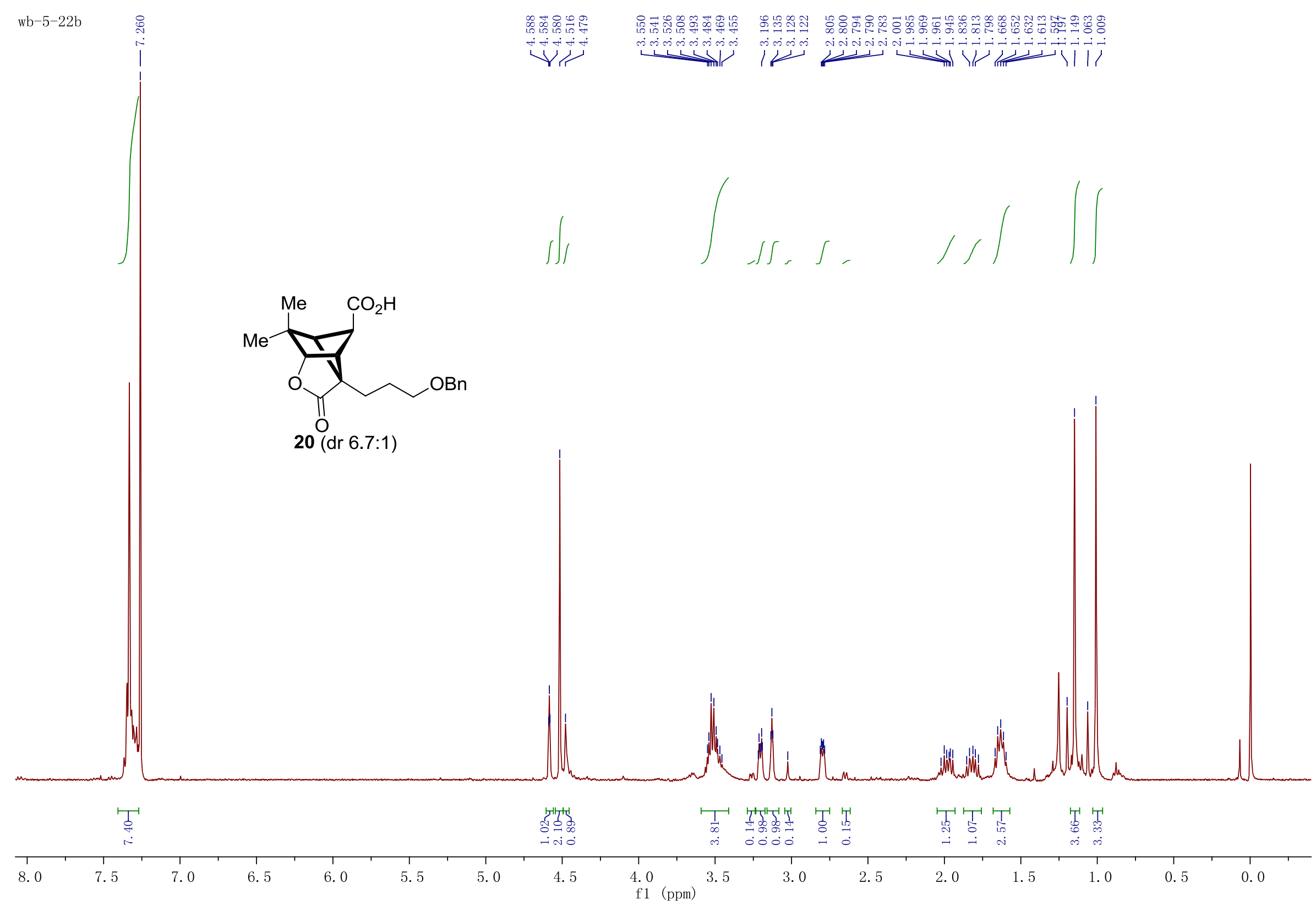




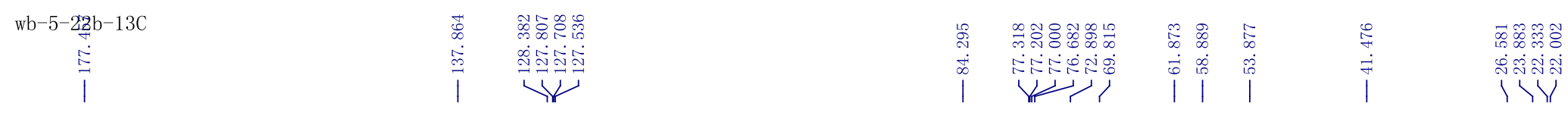
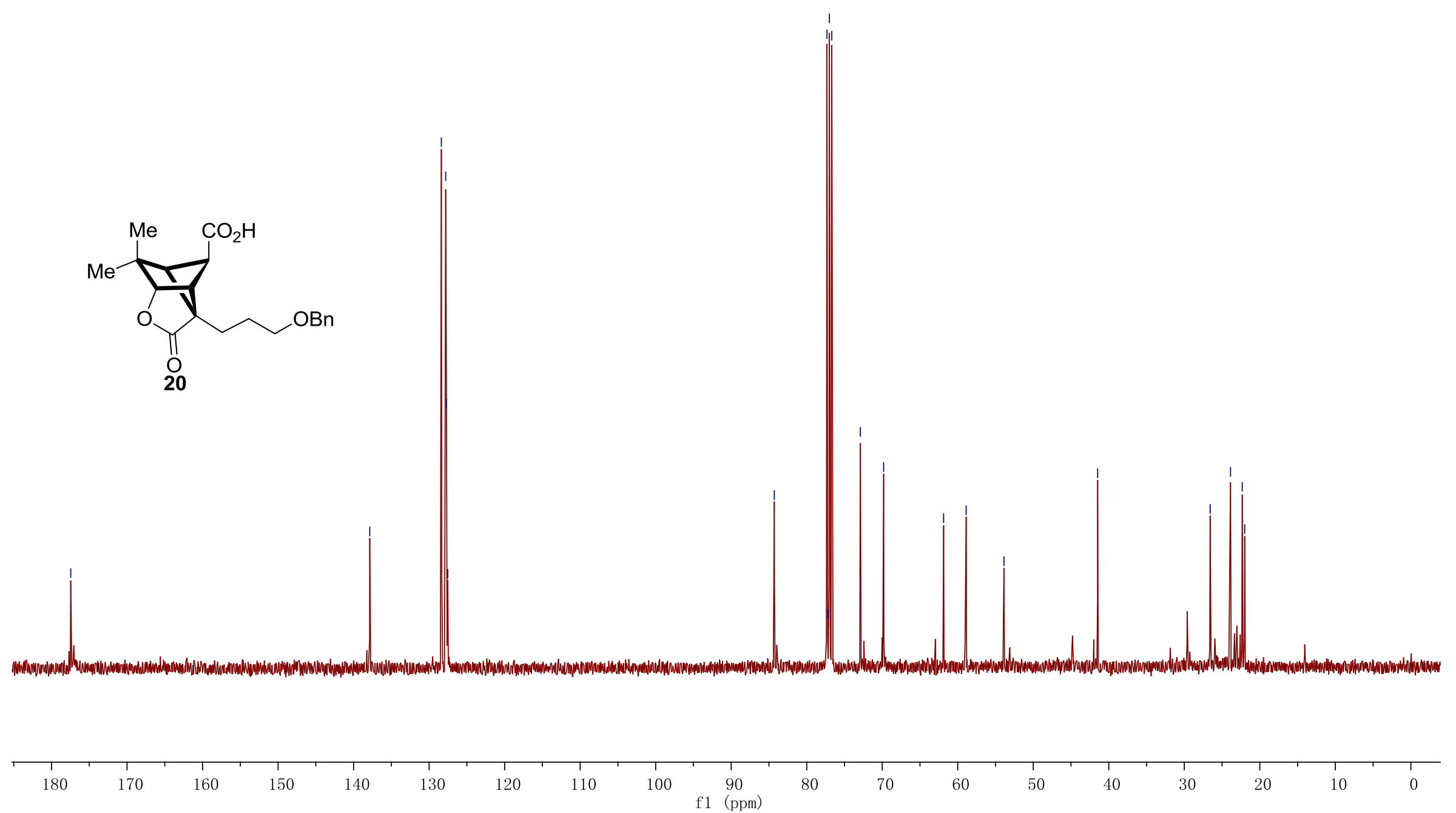


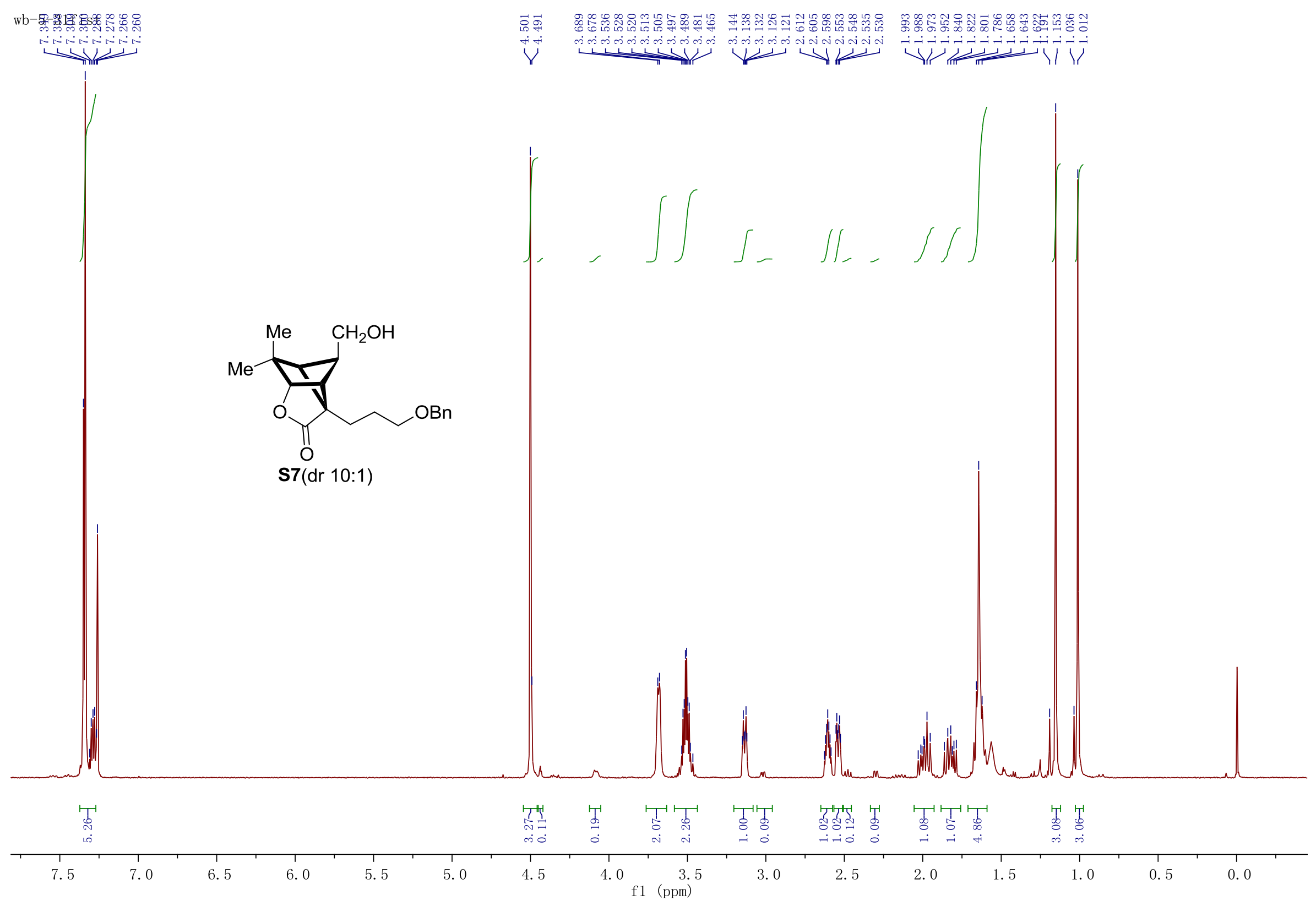



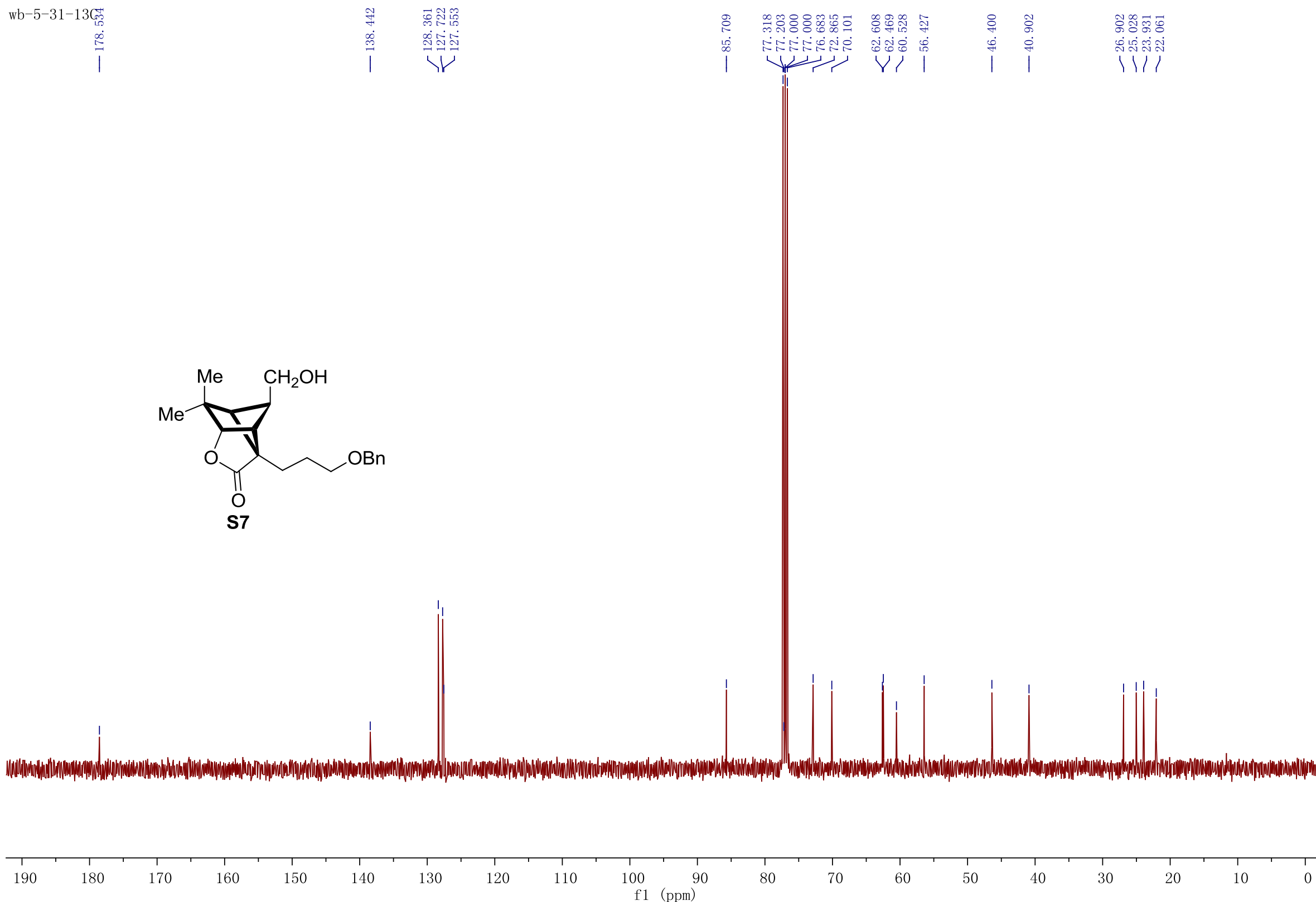


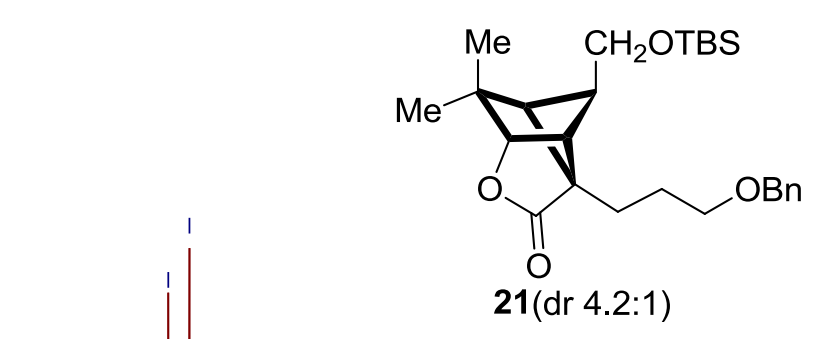

21(dr 4.2:1)

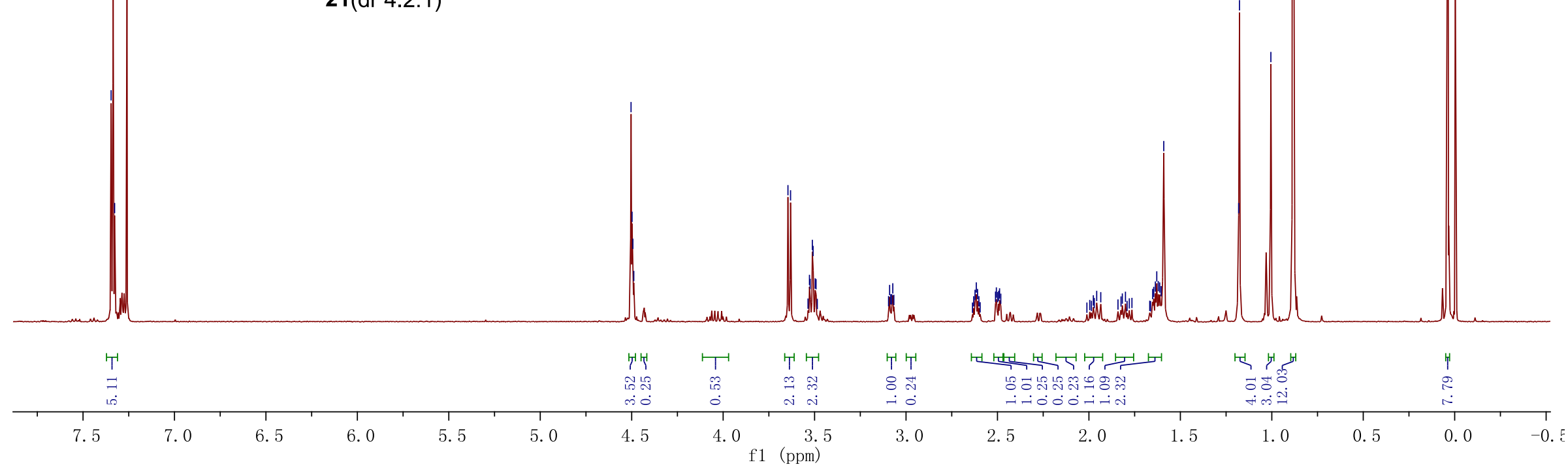


wb-5원 $9-13 \mathrm{C}$

$\stackrel{\infty}{\stackrel{\infty}{1}}$

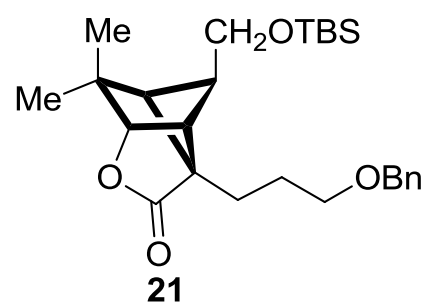

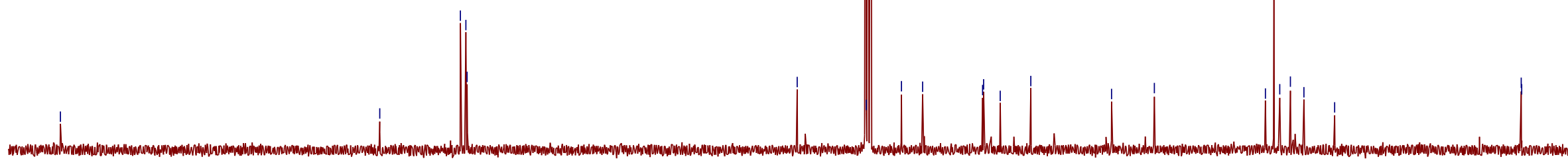

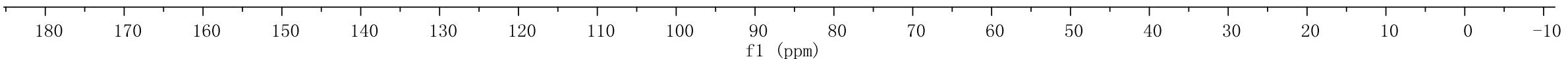




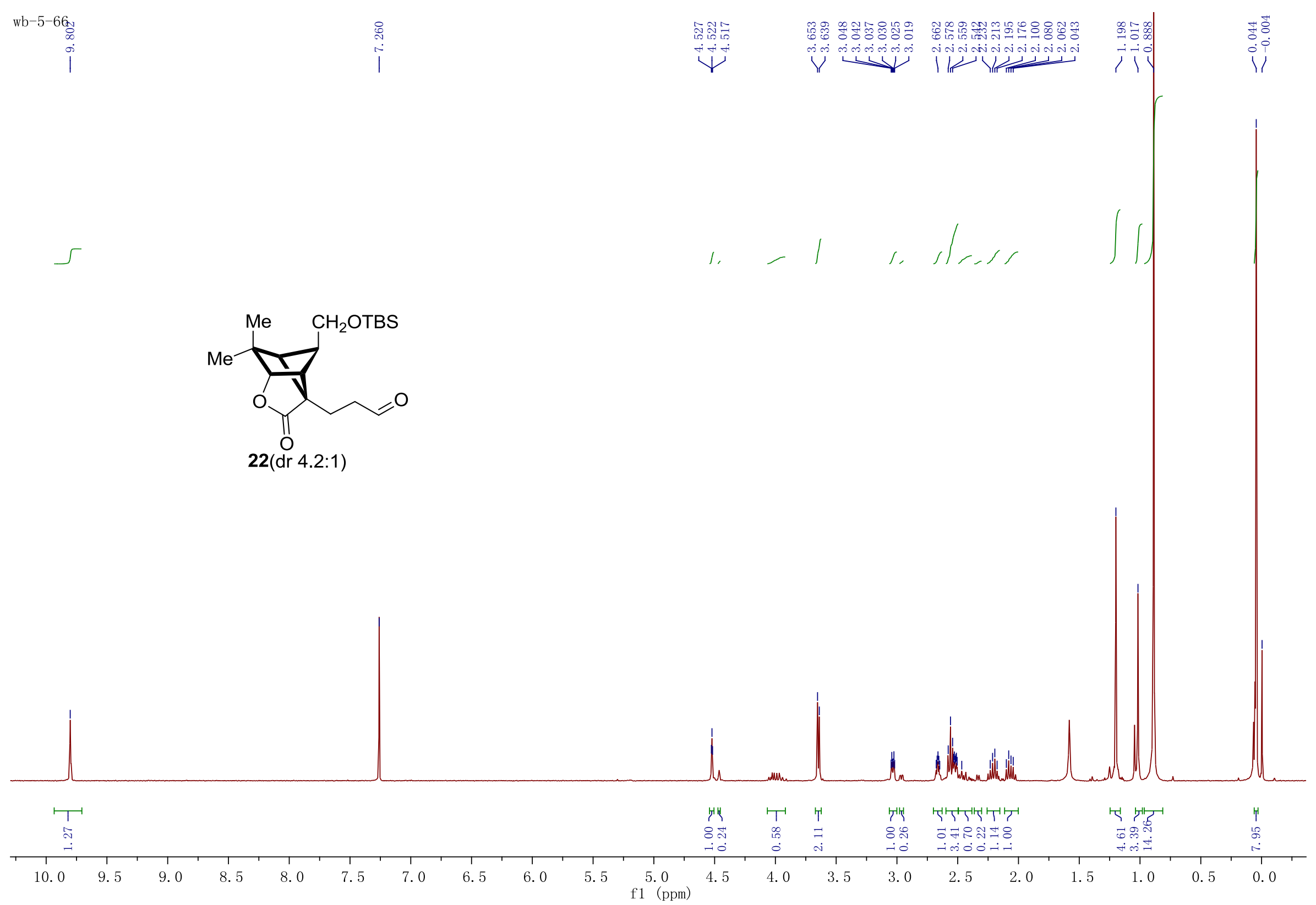



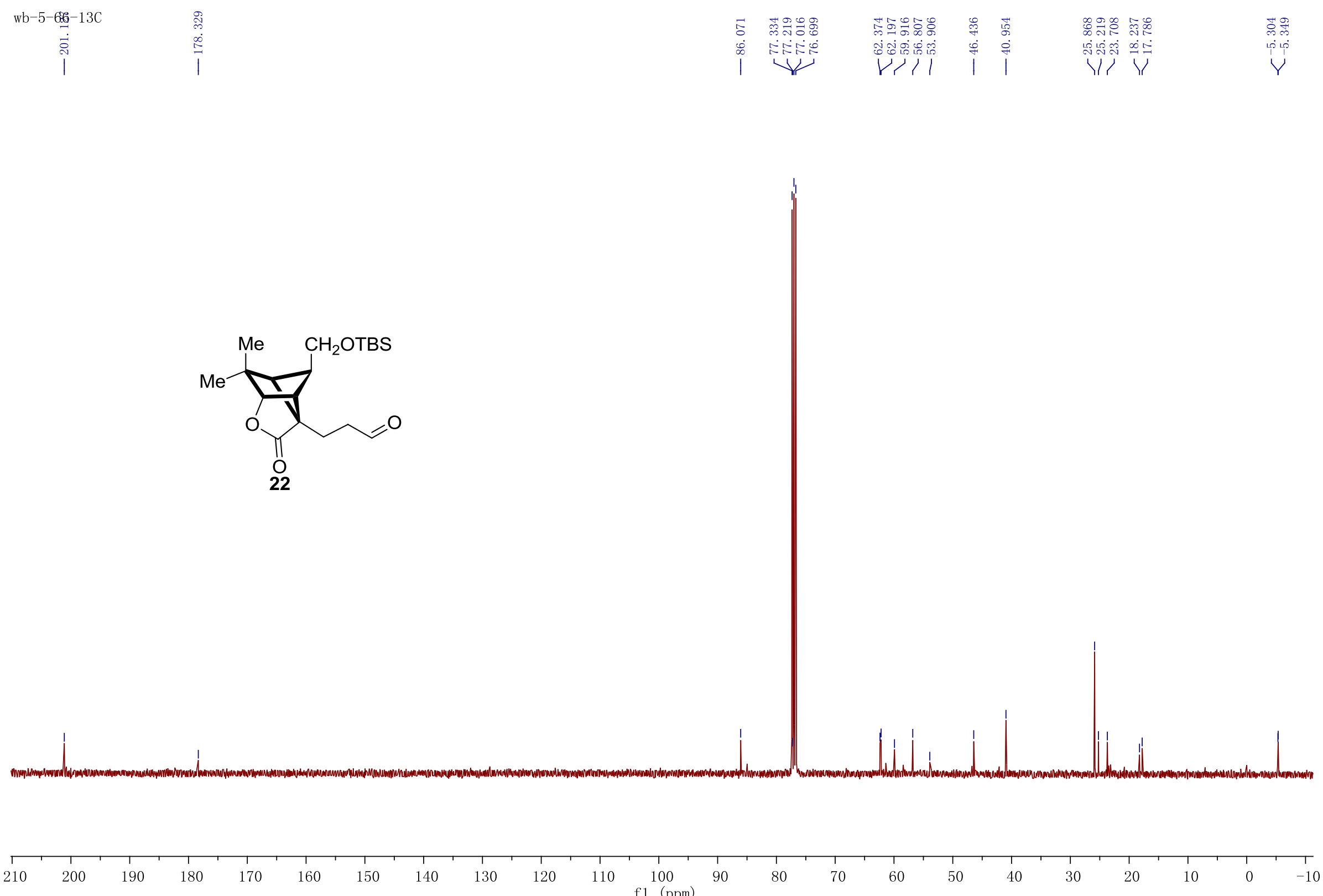


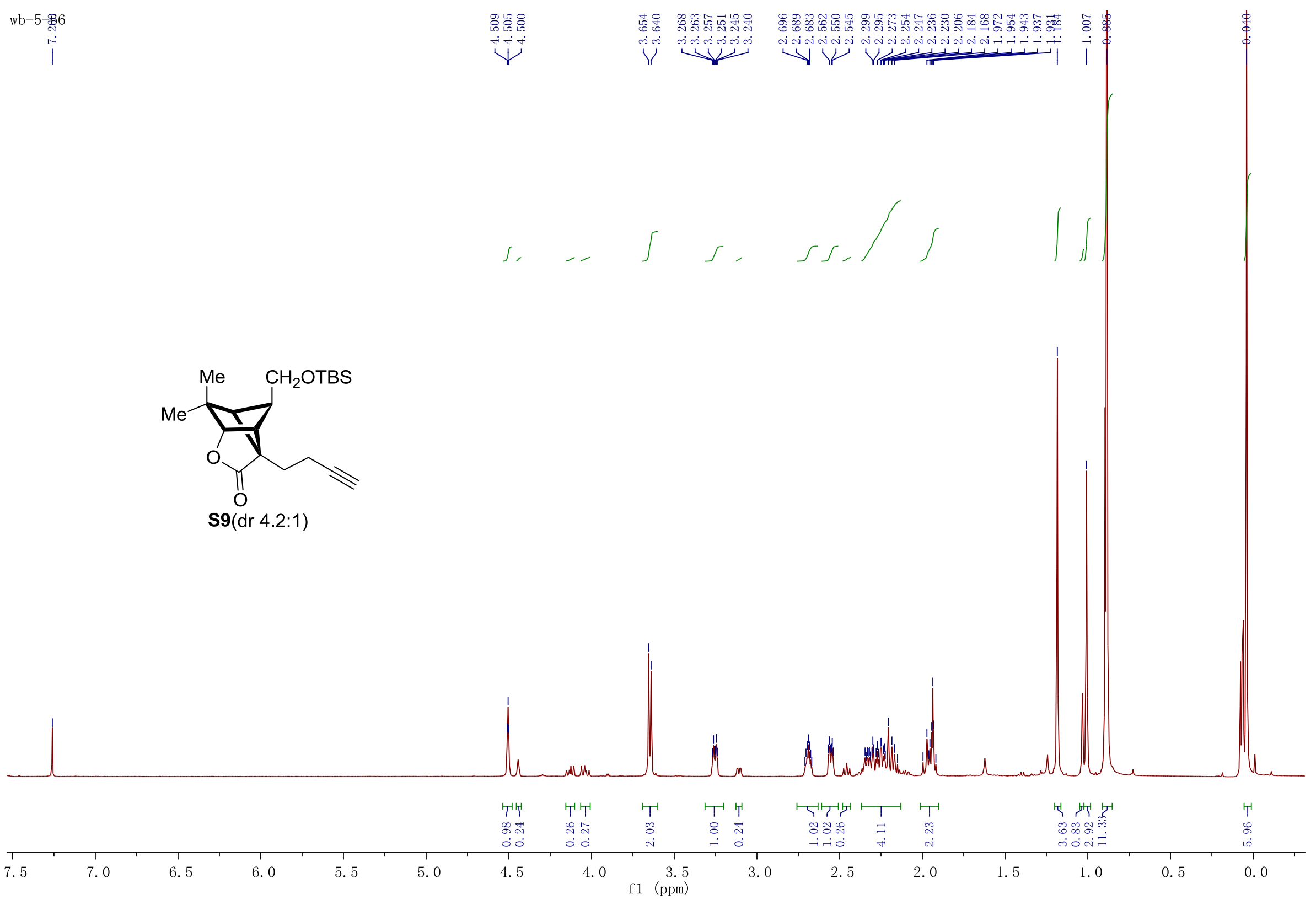




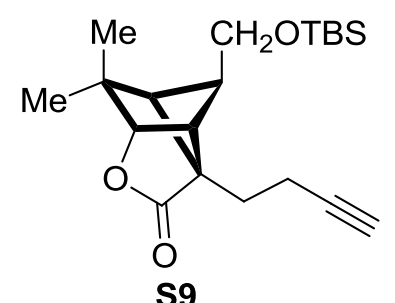

S9
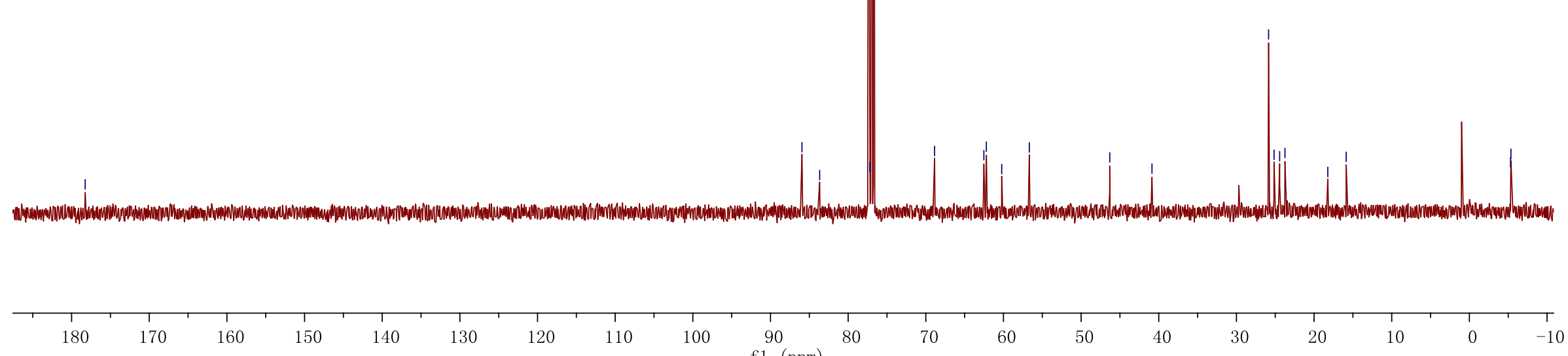


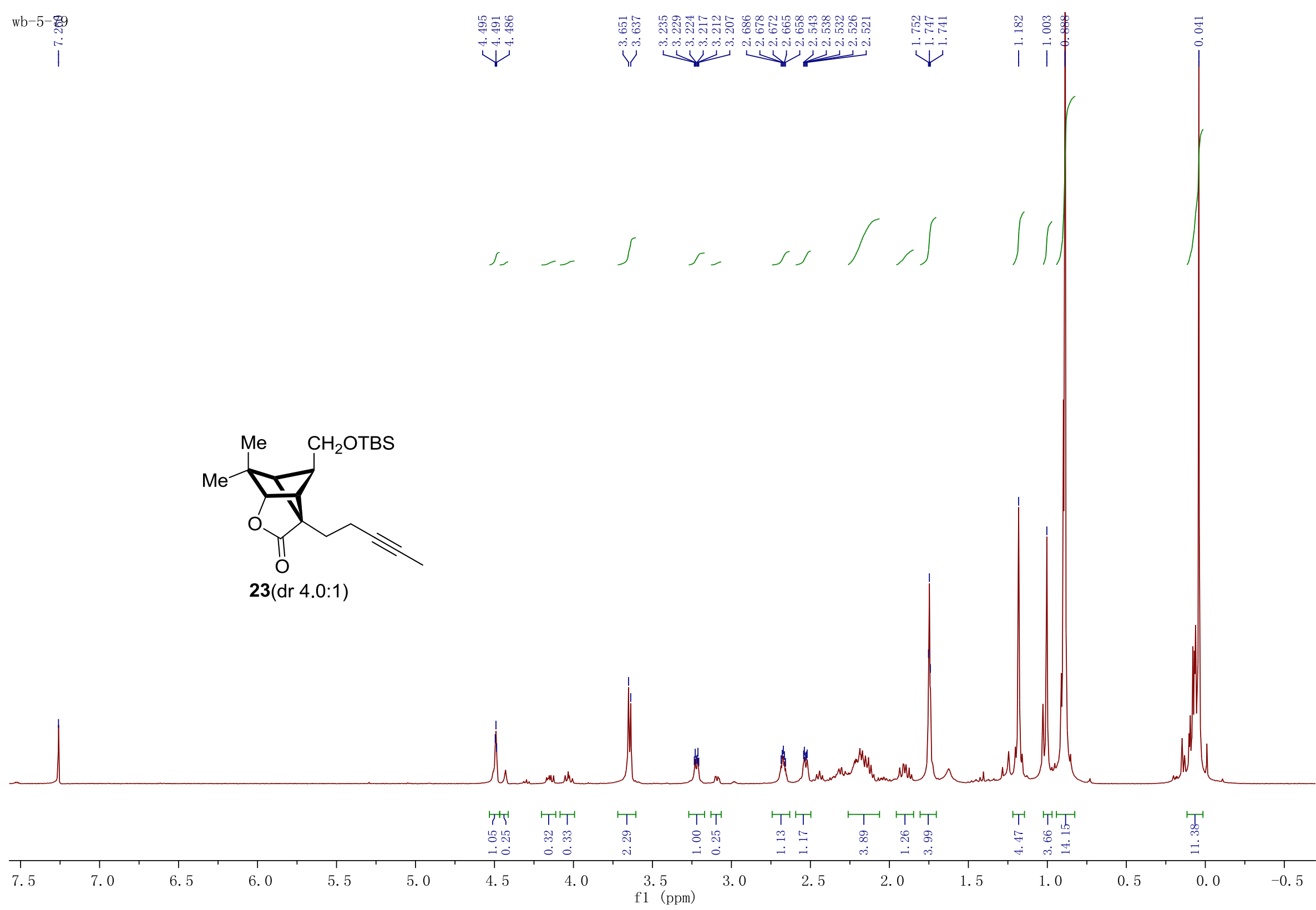


wb- $-79-13 \mathrm{C}$

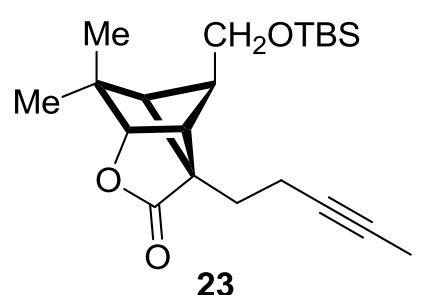

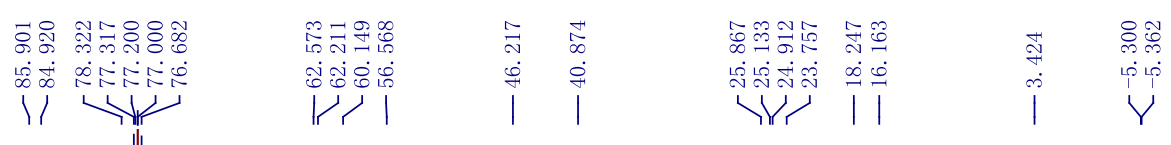

23
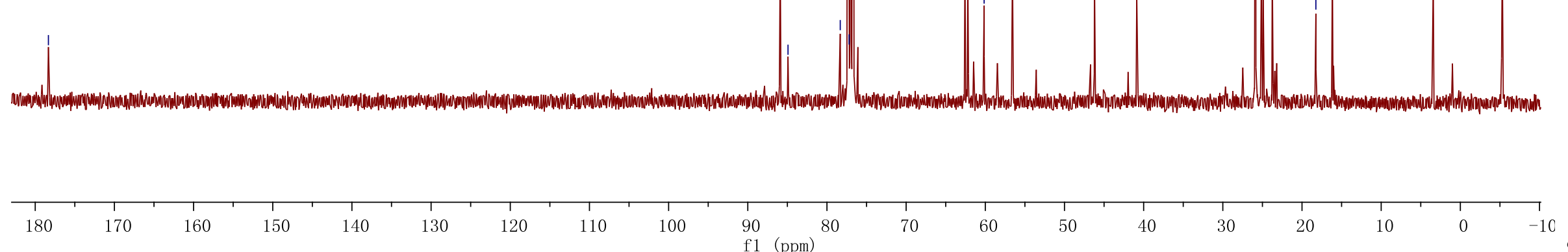


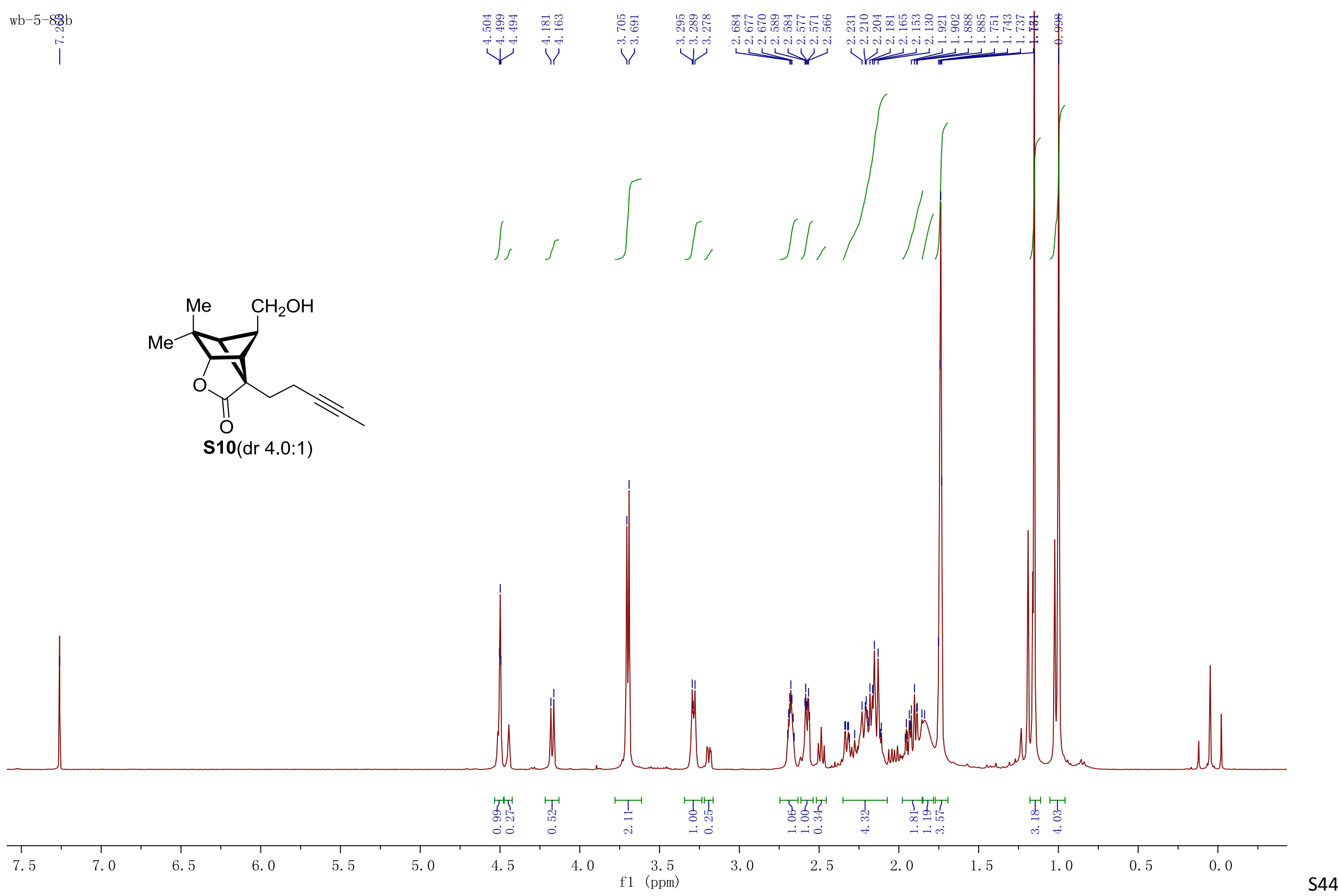




\section{施}

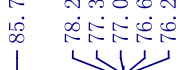

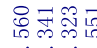

И่

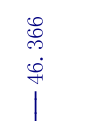

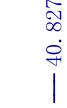

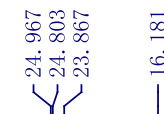

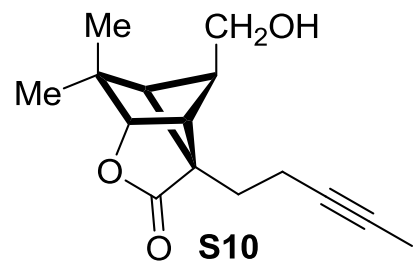

O 510

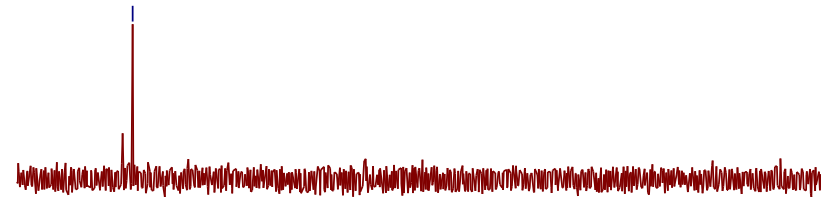

minting ind

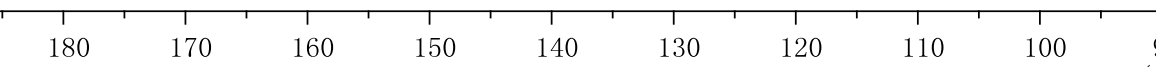




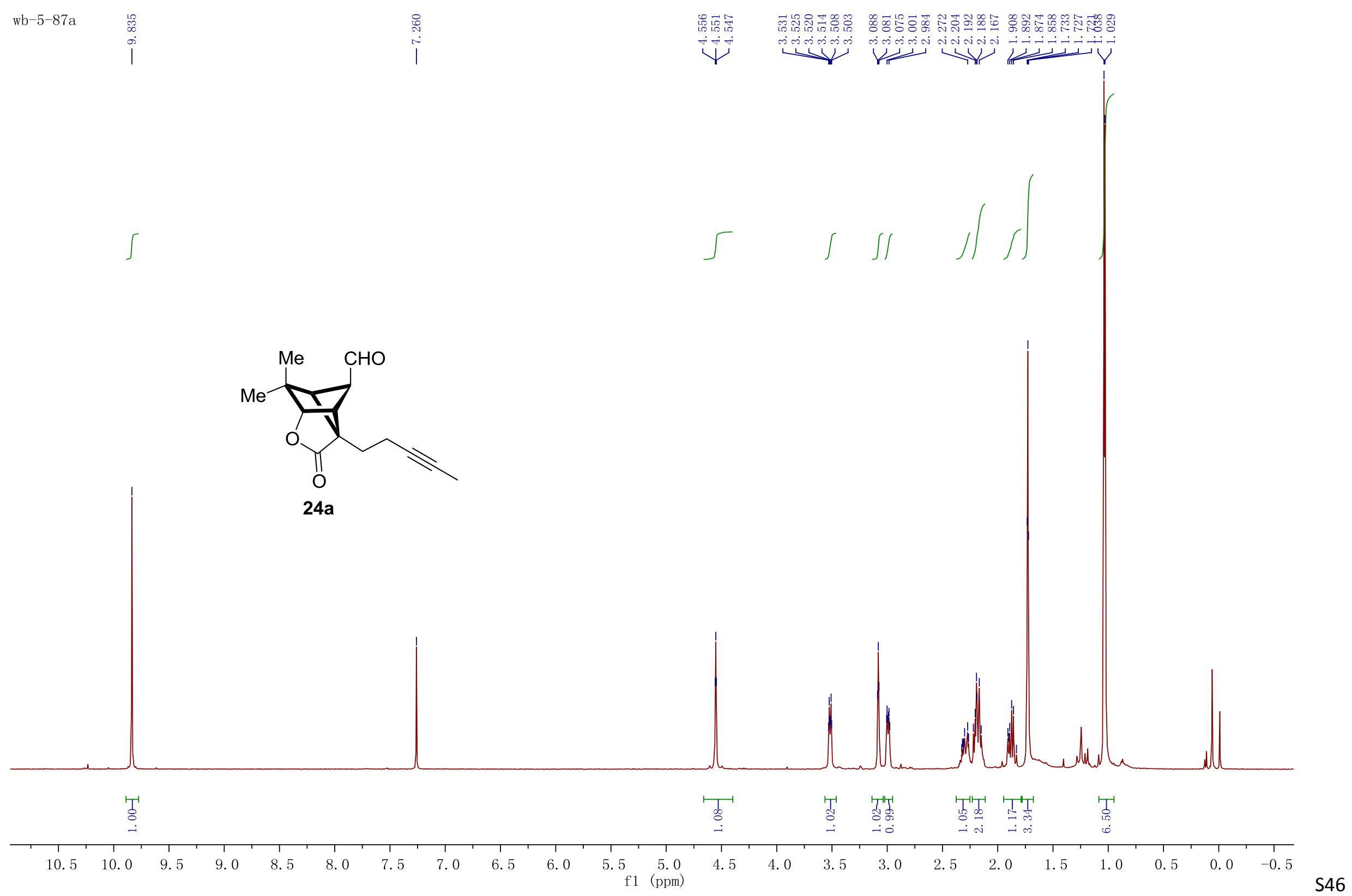




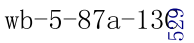

5
5
0
1

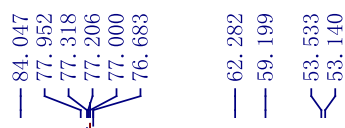

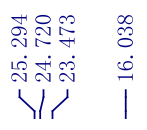

$\stackrel{m}{m}$

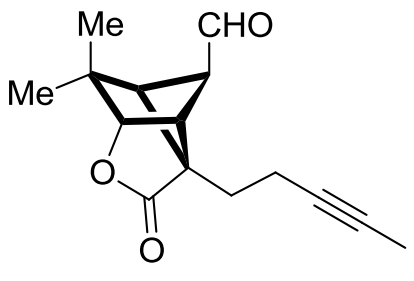

24a
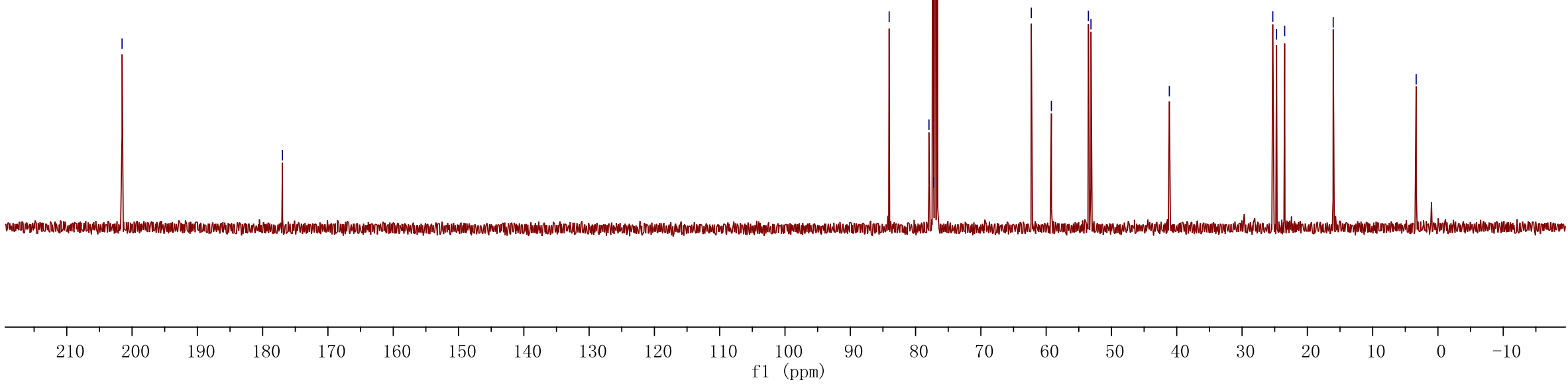

S47 


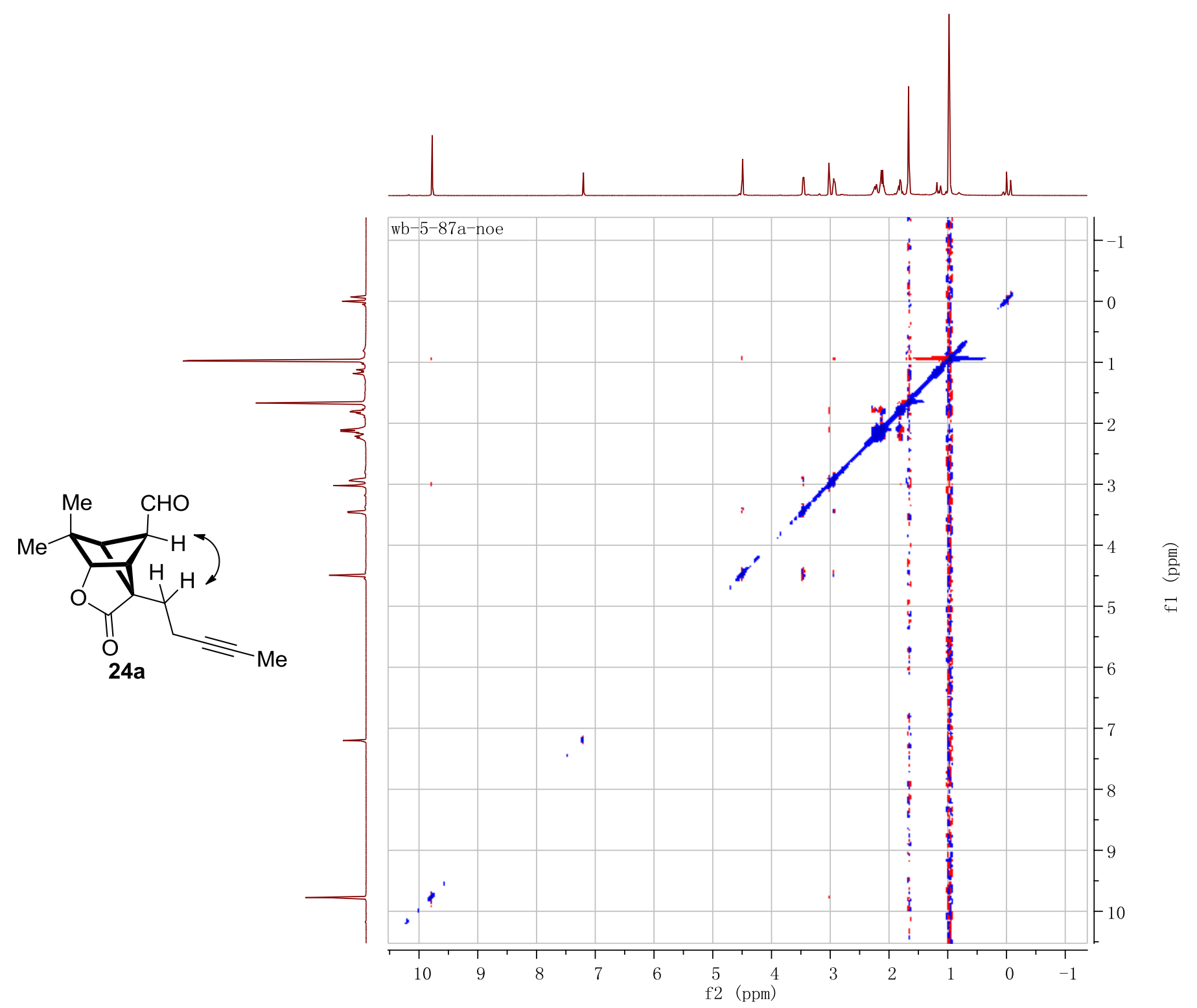



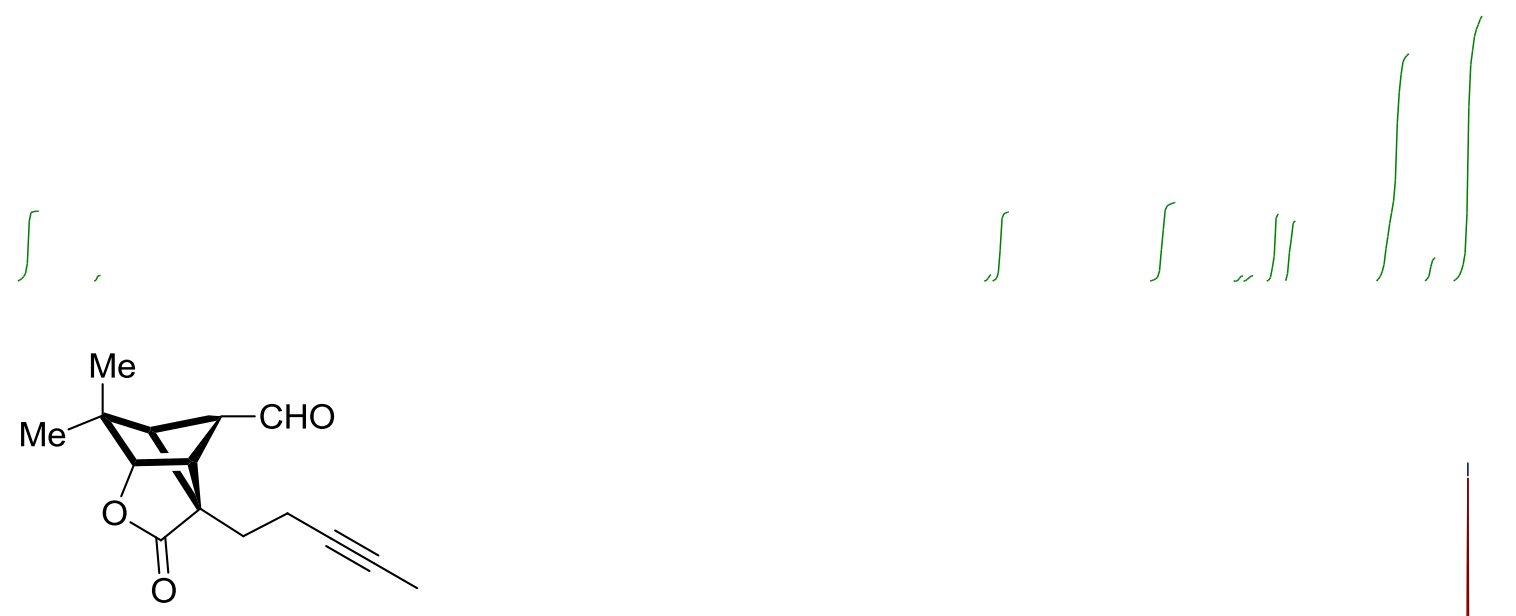

24b (dr 12:1)

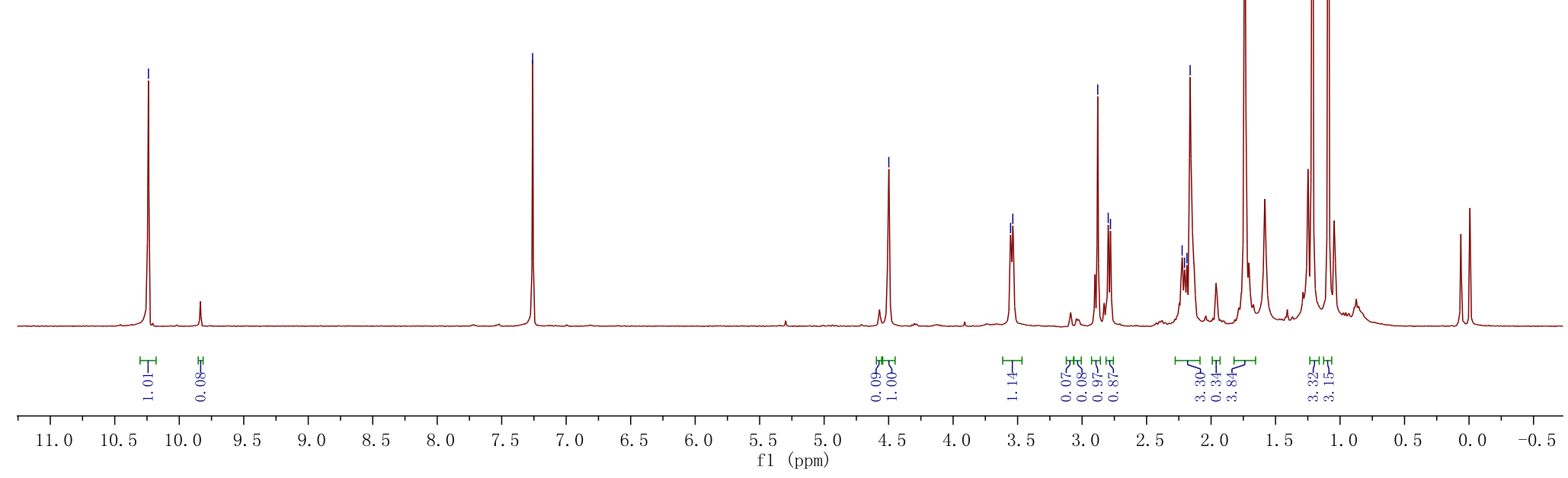




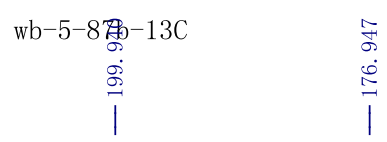

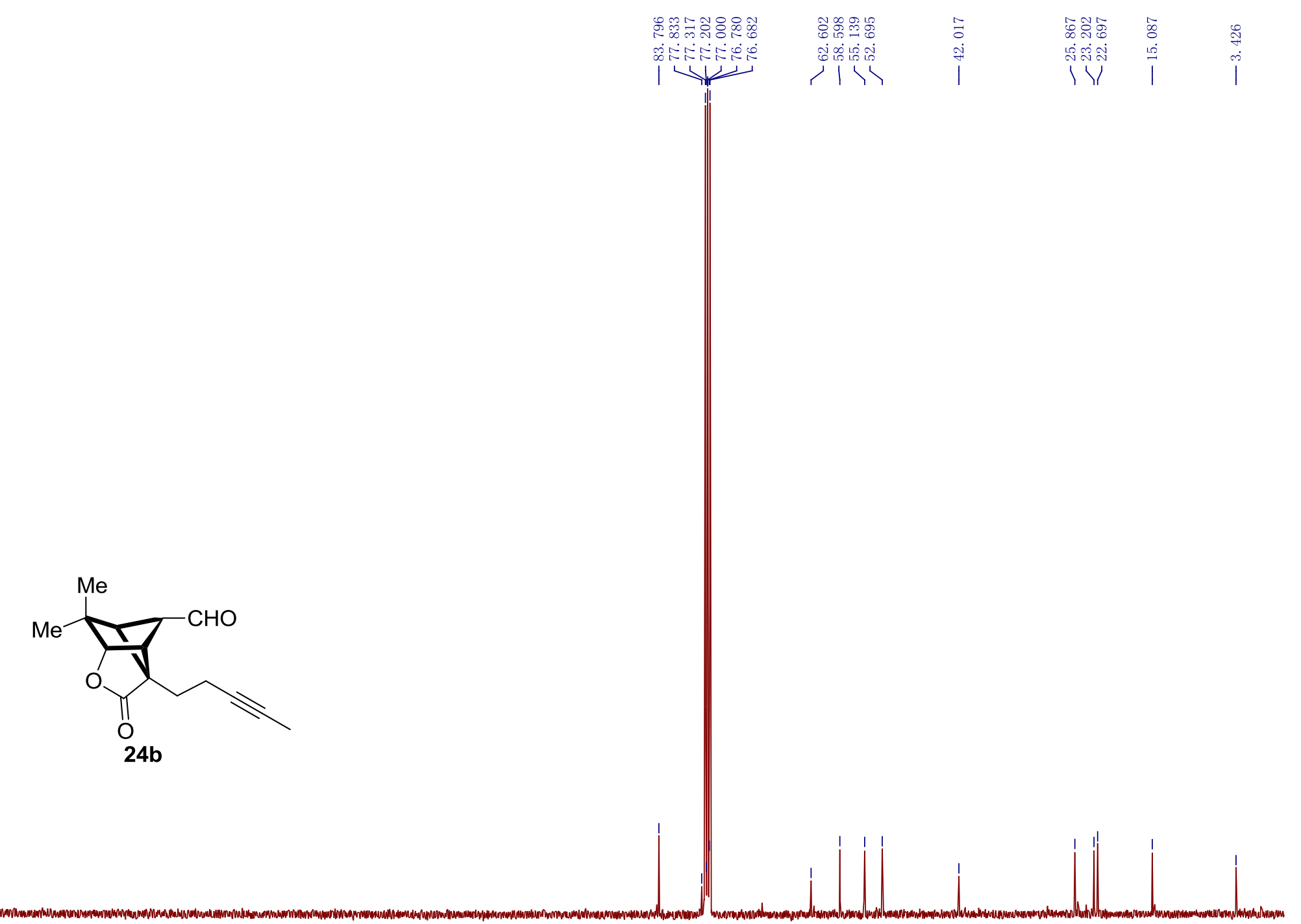

200 


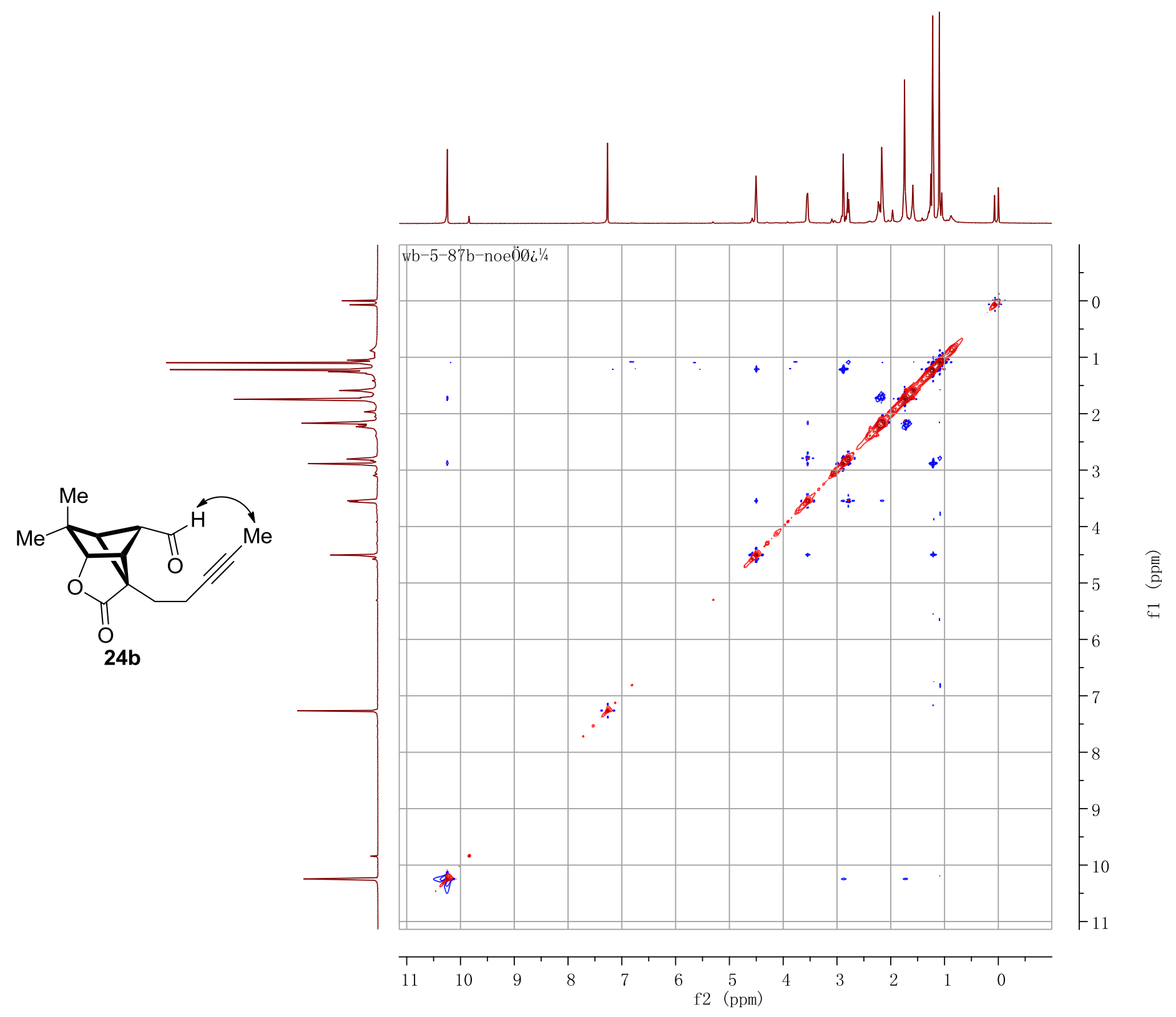




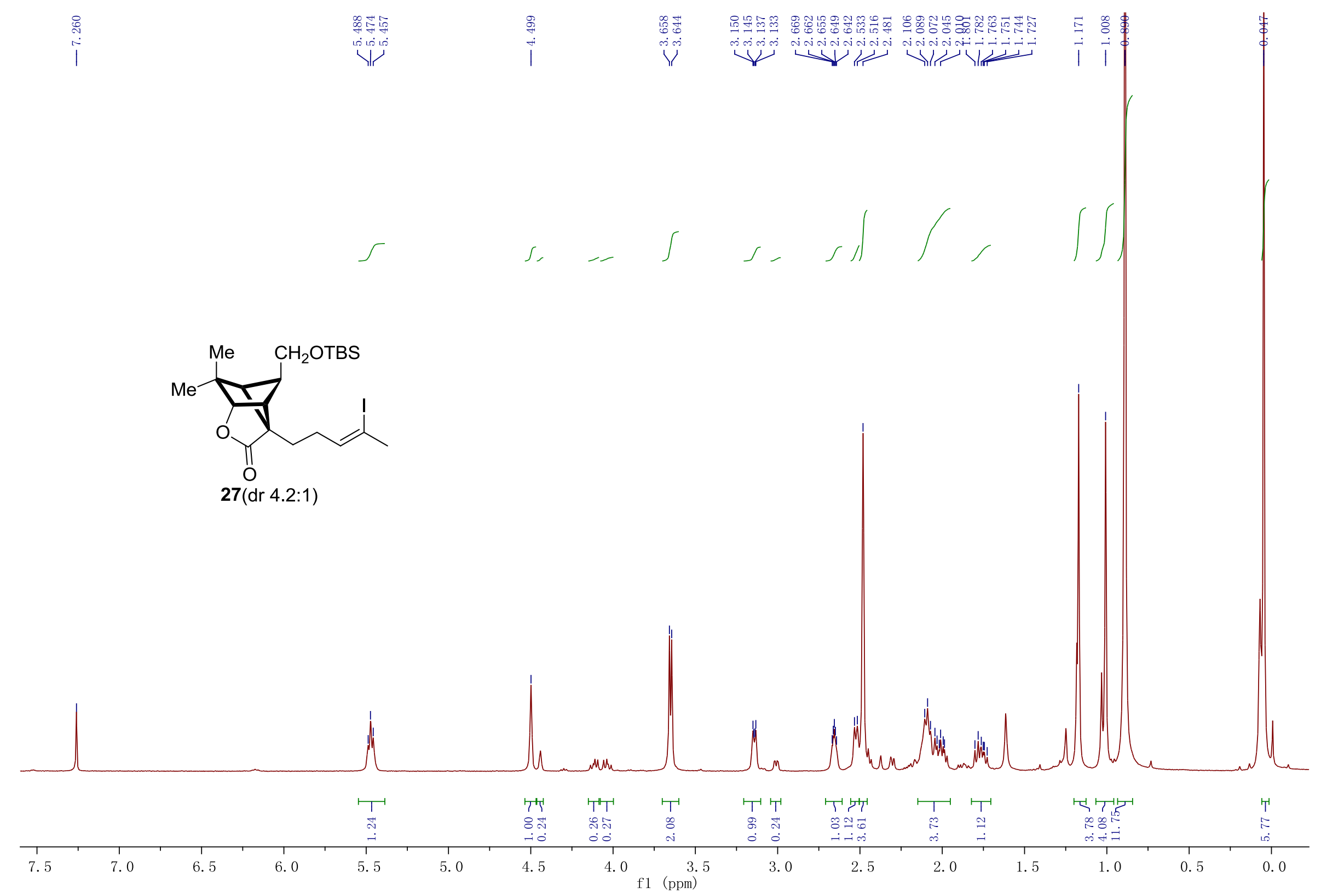



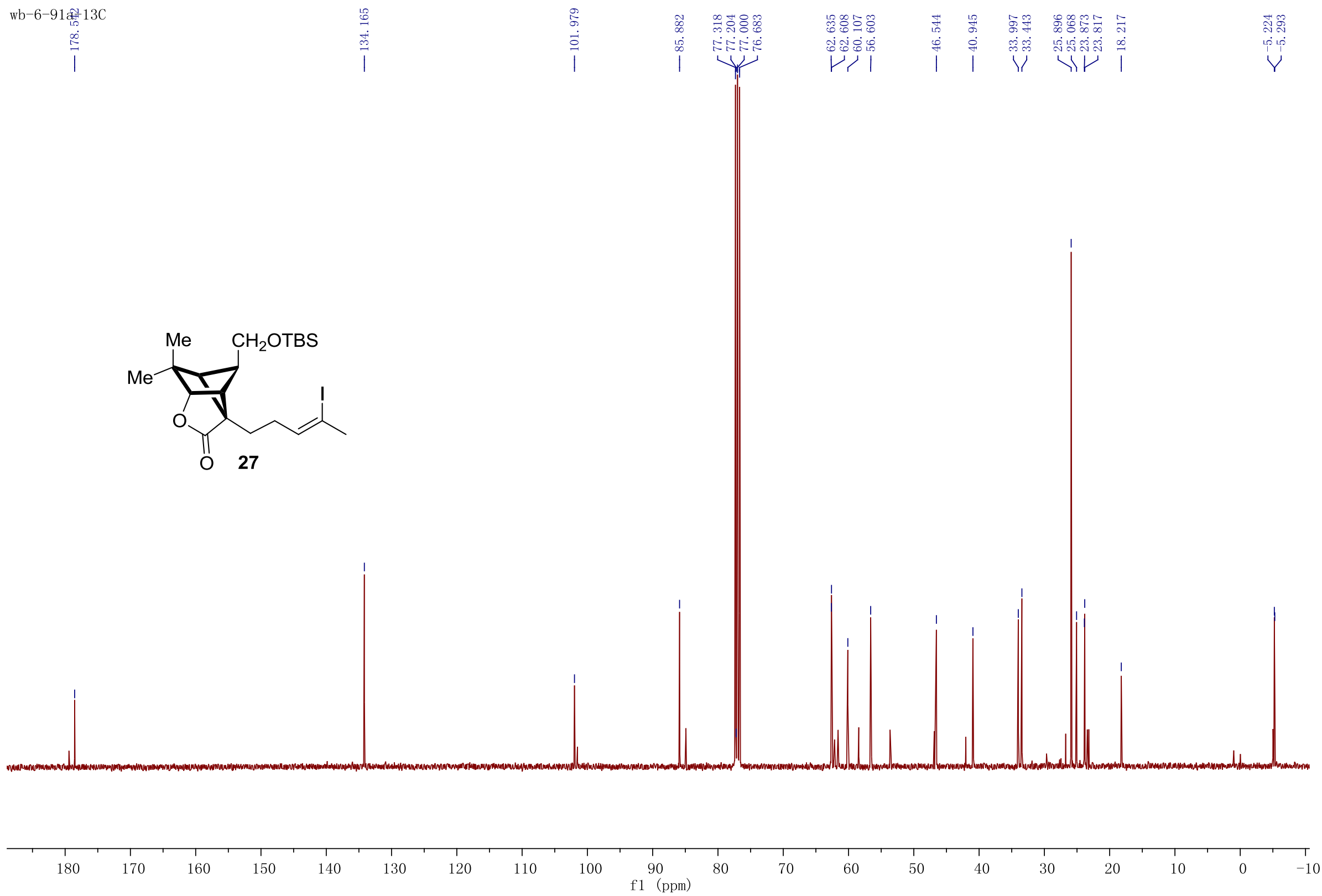


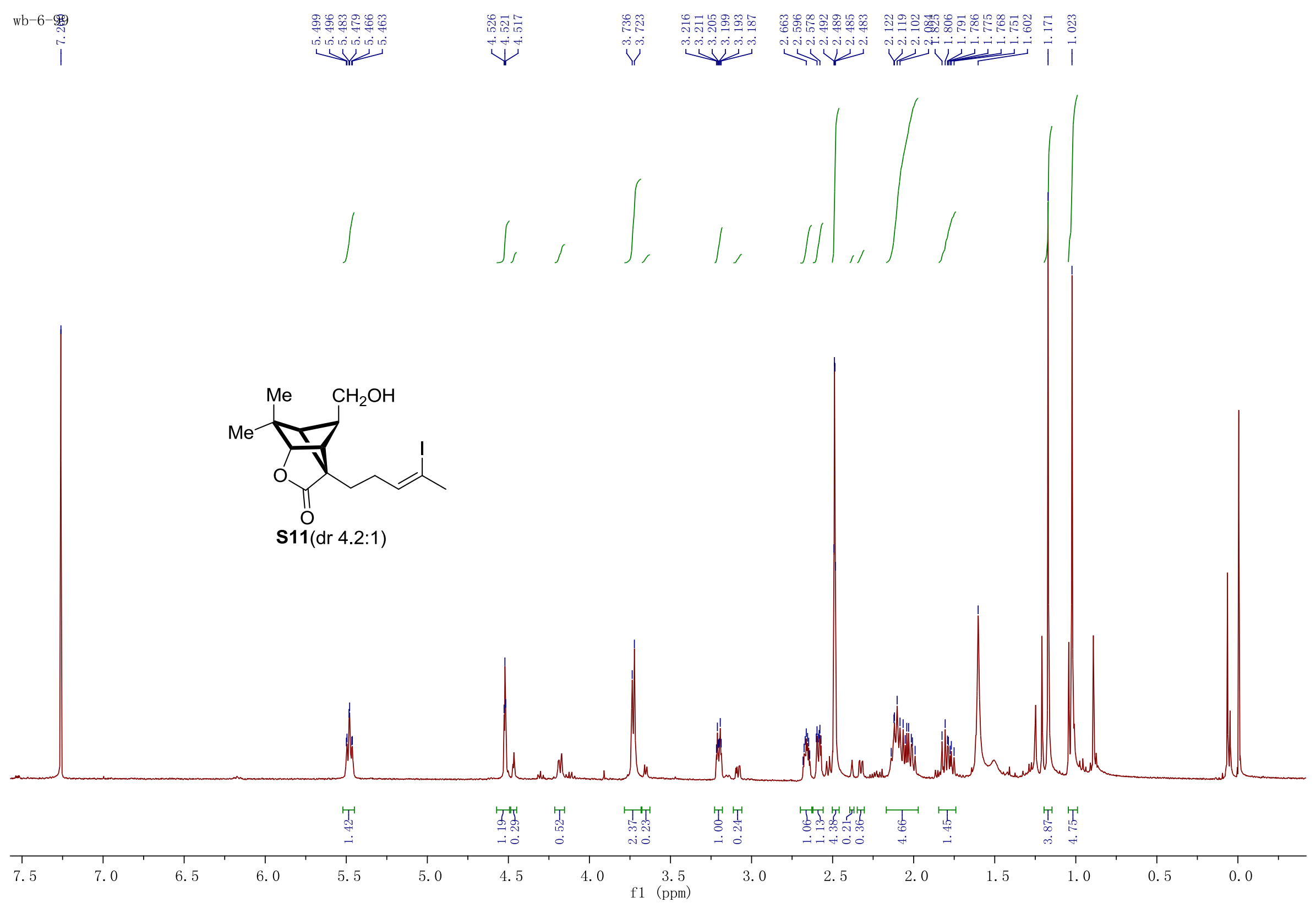


wb-6-78-13C

i
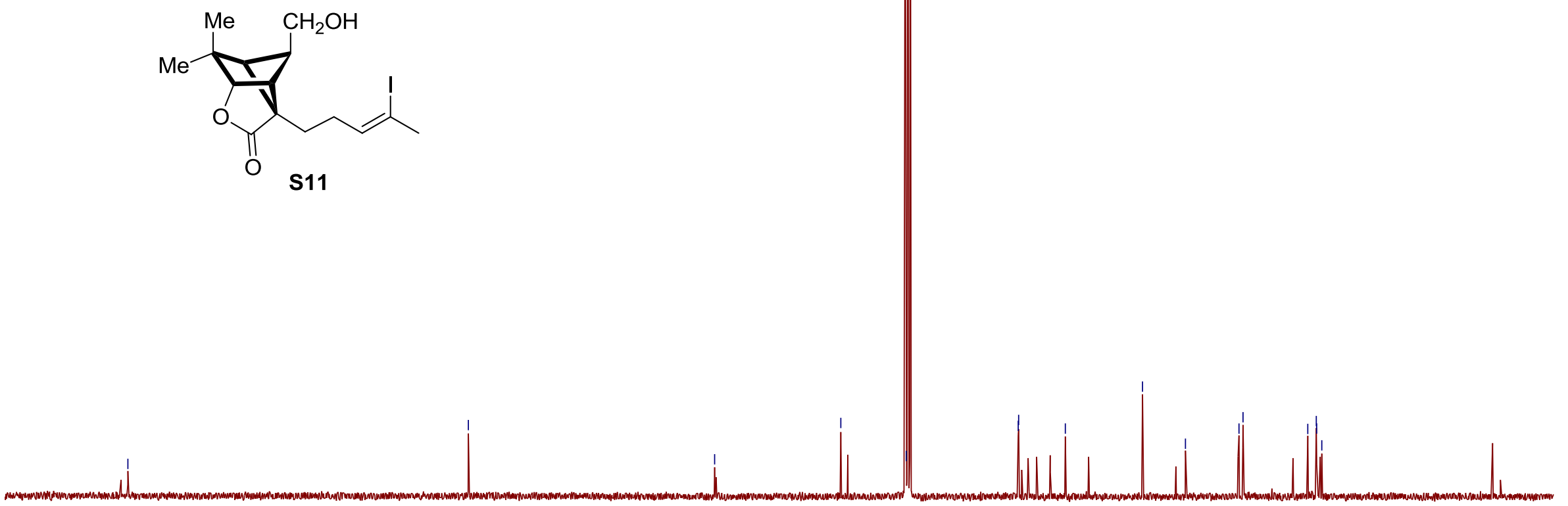


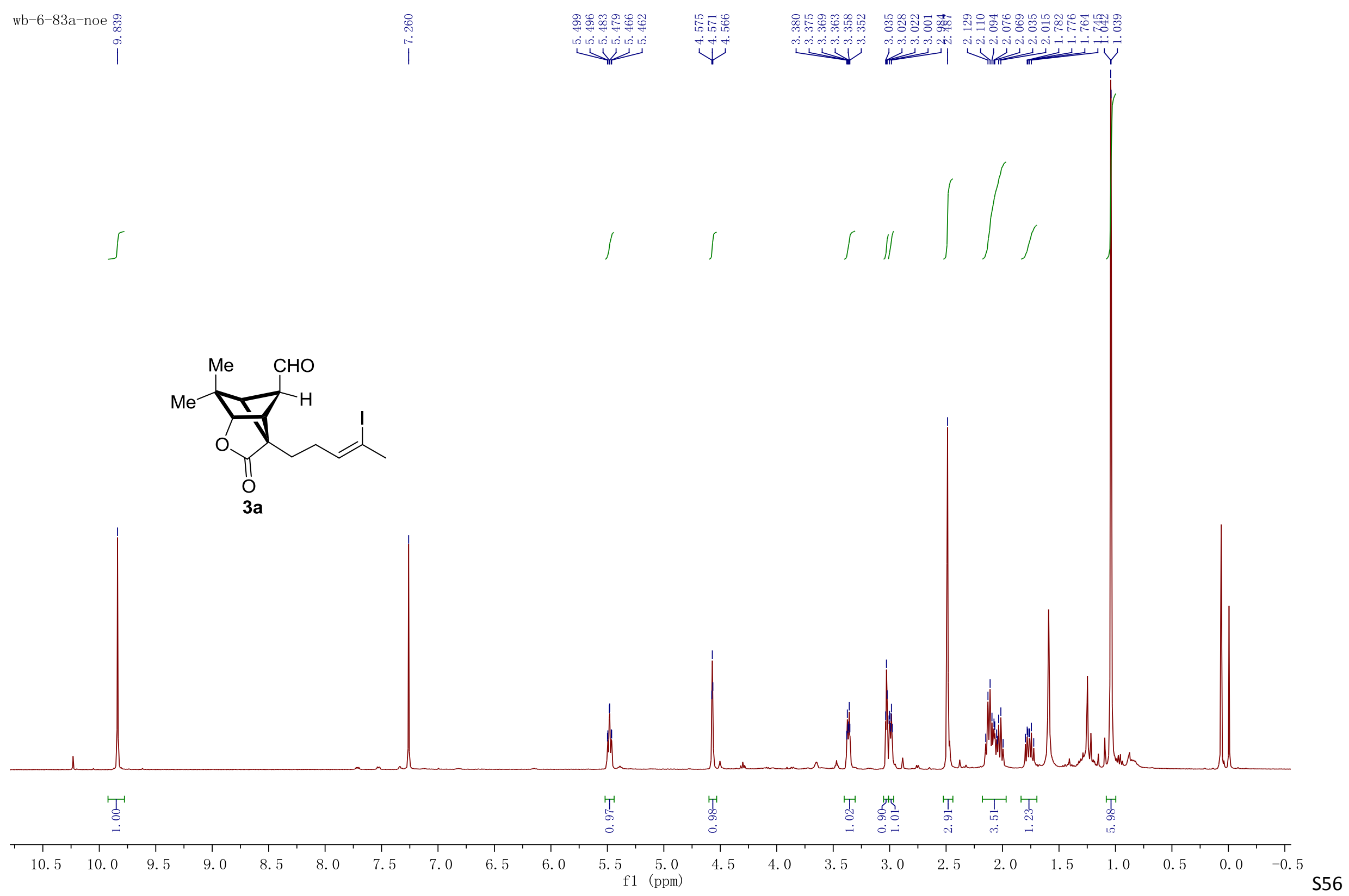



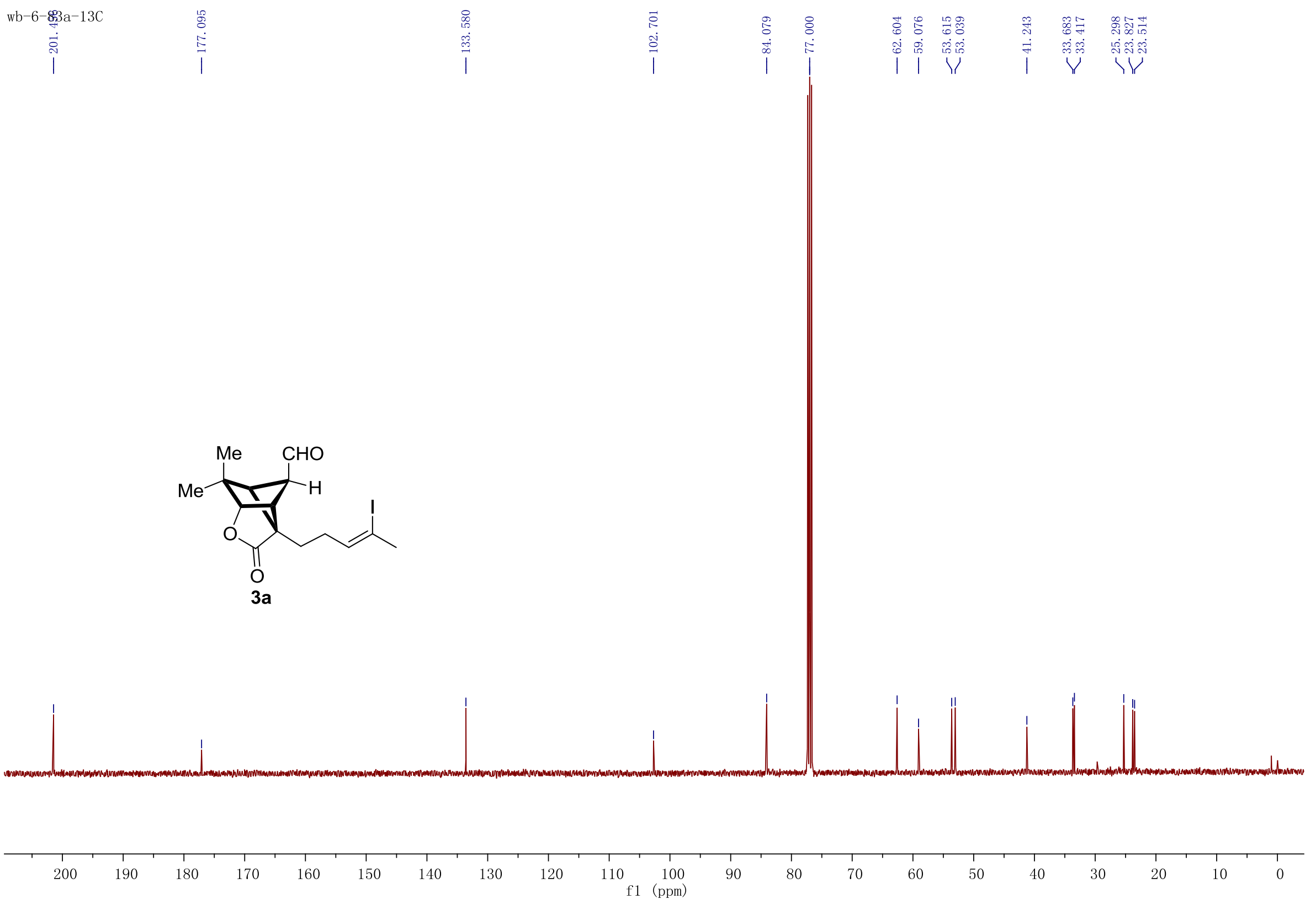


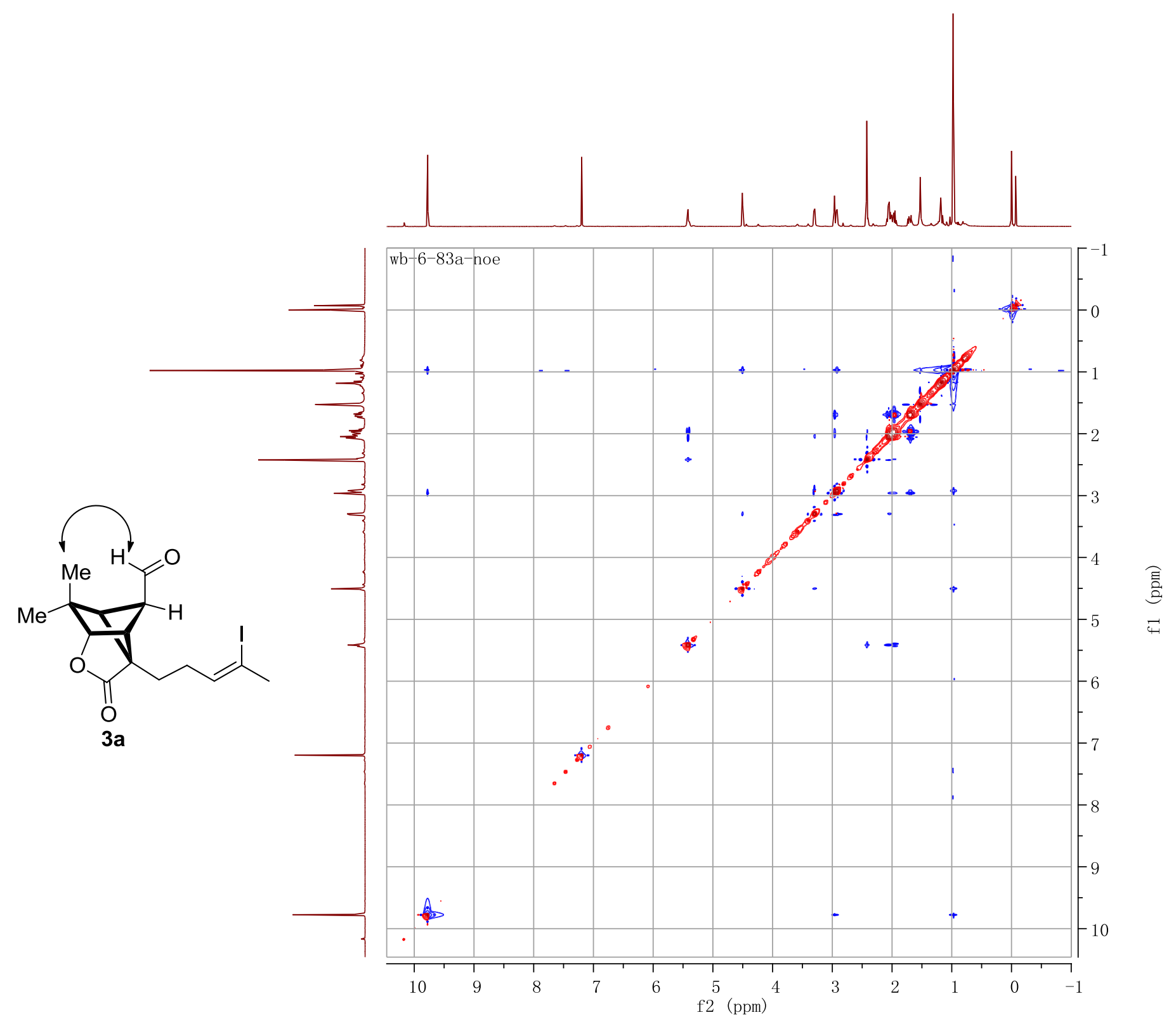




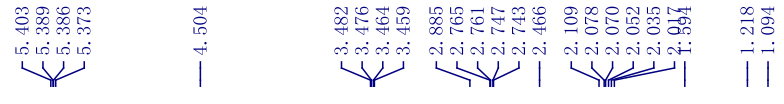
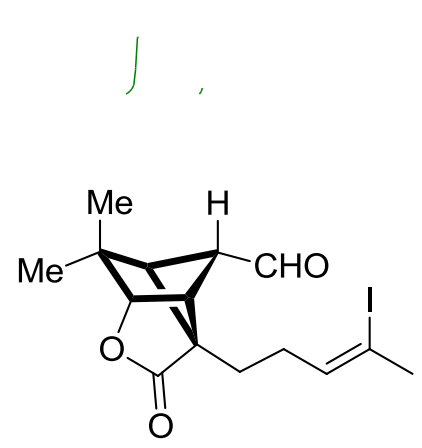

3b (dr 10:1)

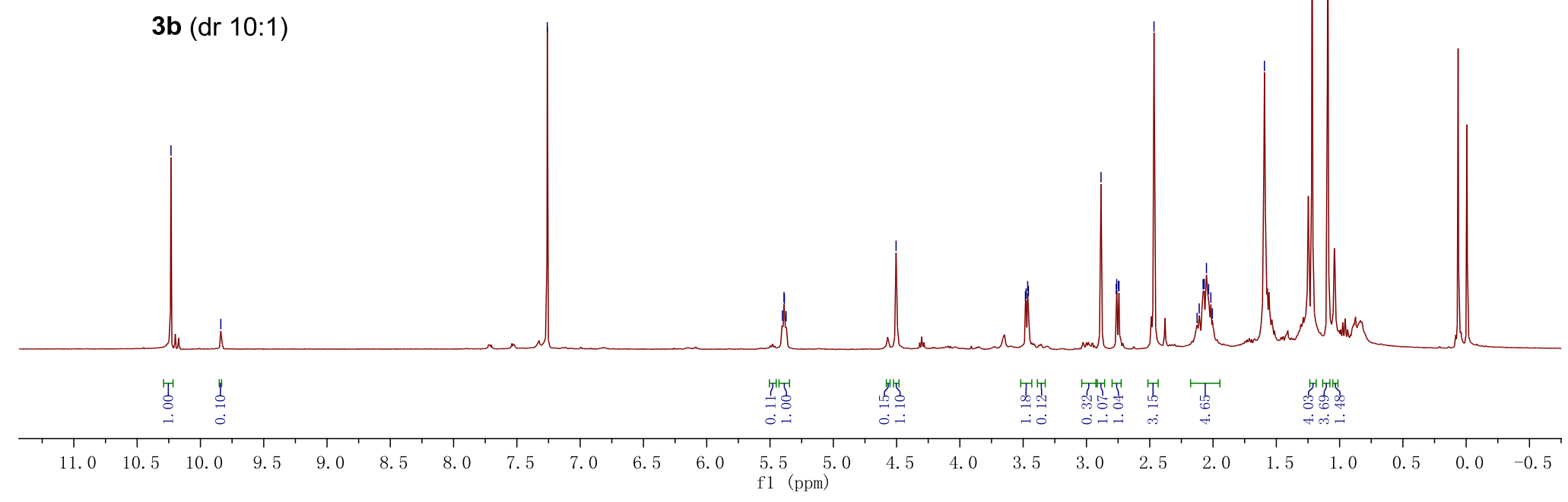




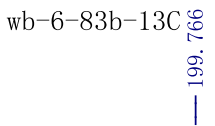

\begin{tabular}{l}
$\infty$ \\
\multirow{0}{0}{} \\
\multirow{2}{*}{}
\end{tabular}

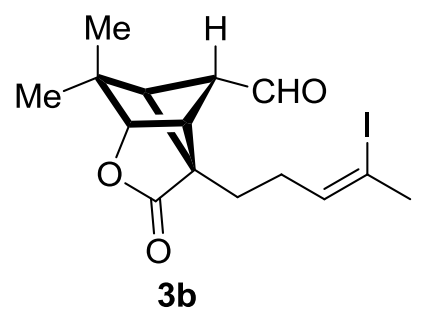

|

0
$\infty$
$\infty$
$\dot{0}$
1
$\mid$

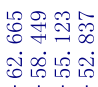

$1|1|$

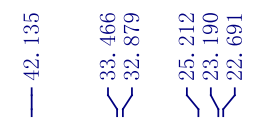

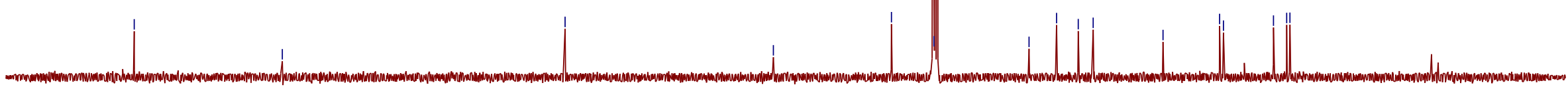

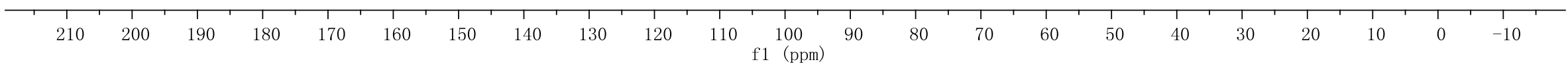

S60 


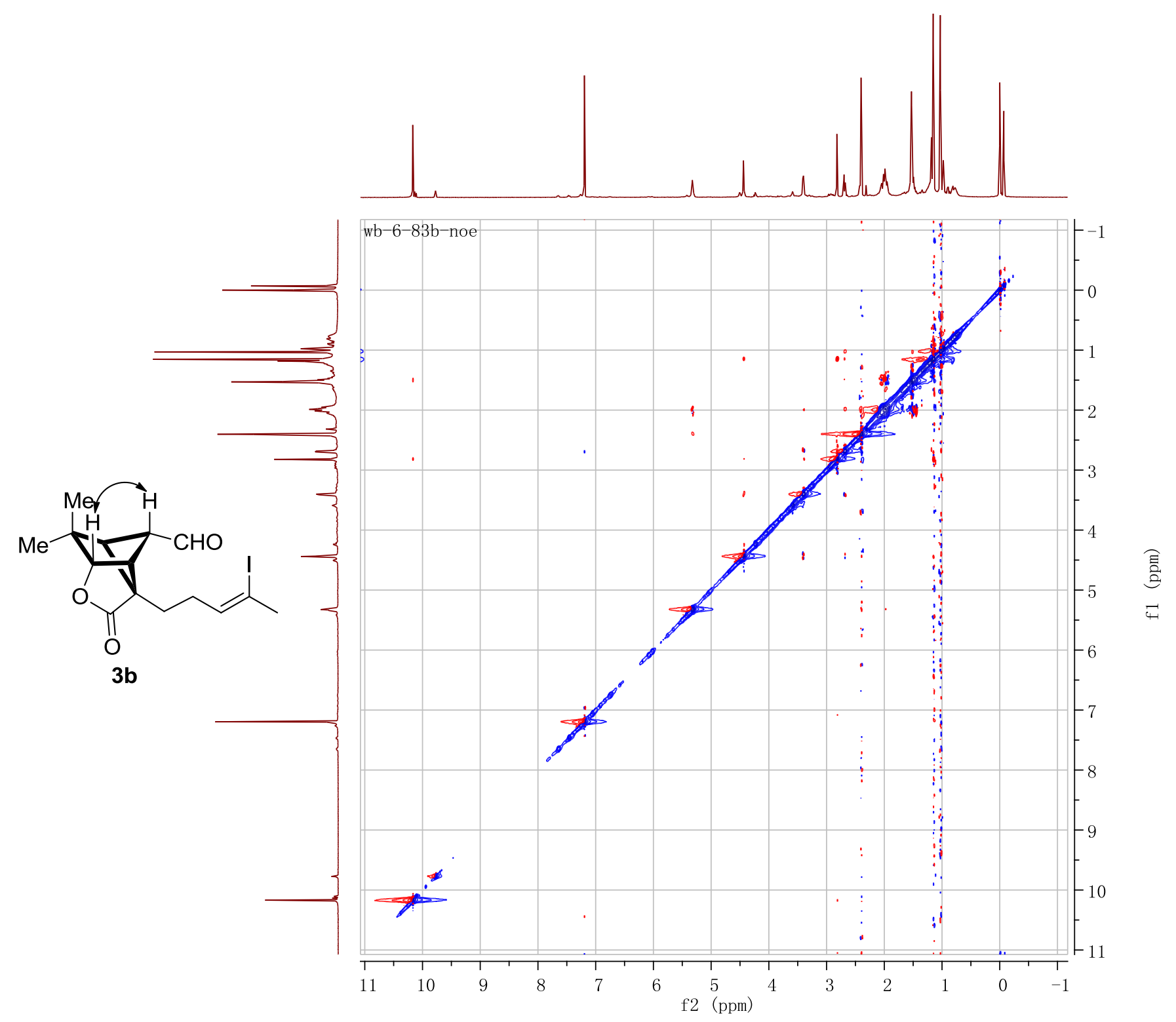




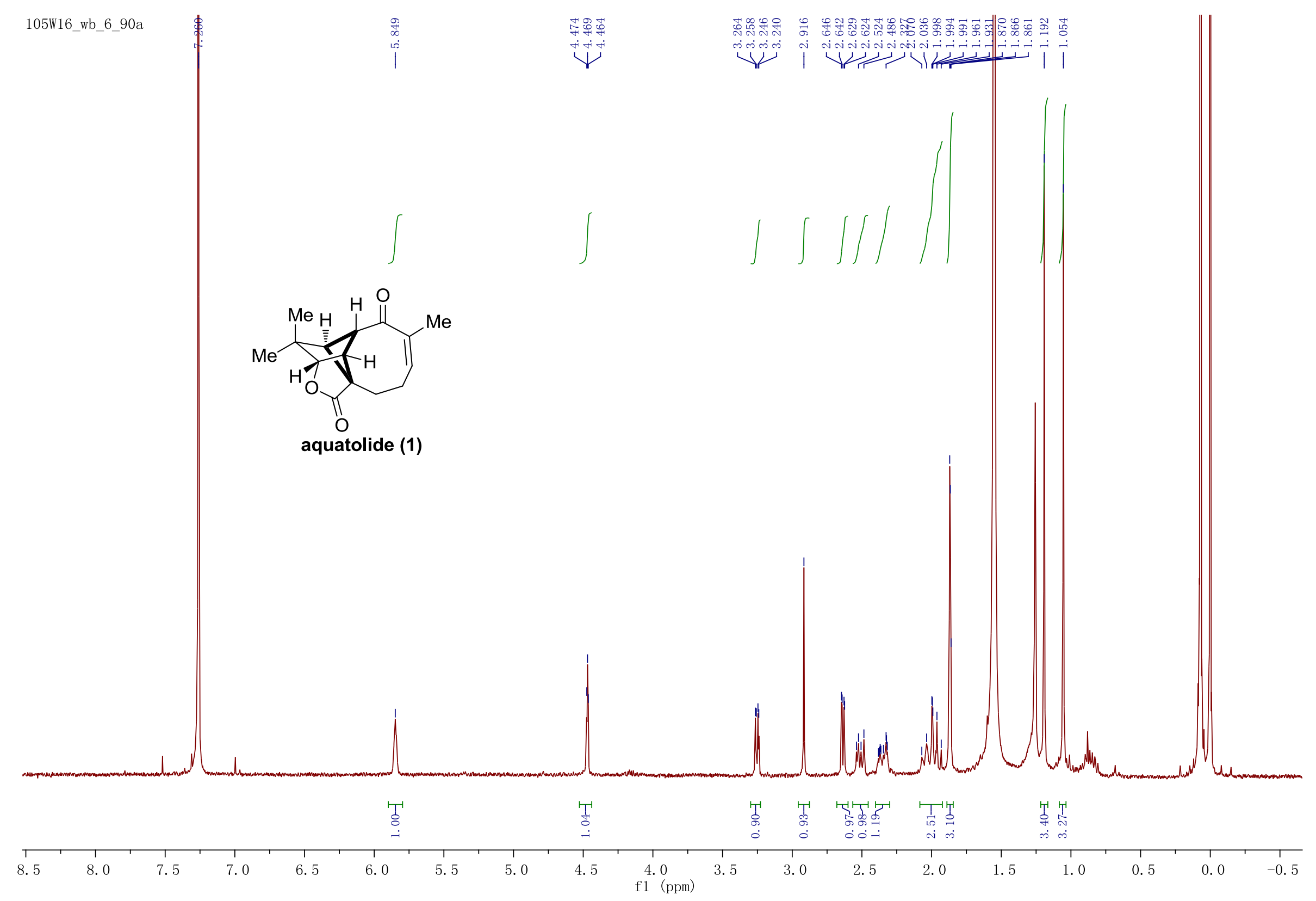



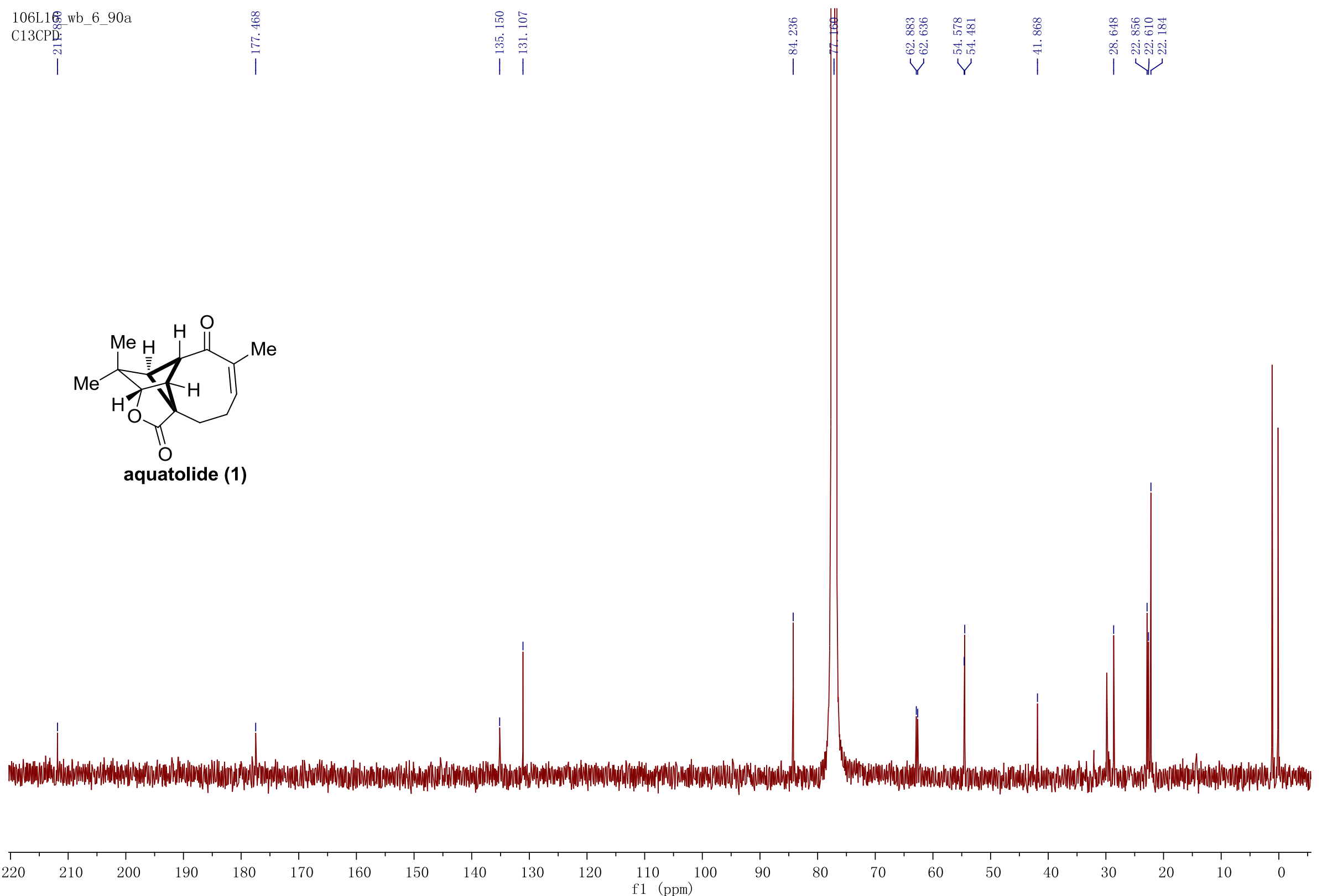